\title{
"They Had, They Thought, Their Champion of Freedom": Social Constructivism and Greek Politics, 217-199.
}

\author{
by \\ Matthew Martel \\ Supervised by W. Jeffrey Tatum
}

A thesis submitted to Victoria University of Wellington in fulfilment of the requirements for the degree of Master of Arts in Classical Studies

Victoria University 


\section{Table of Contents}

Abstract.......................................................................... 2

Acknowledgements..........................................................

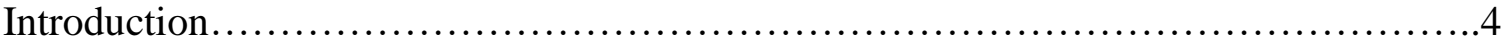

Chapter 1 - Panhellenism "Is What States Make of It"

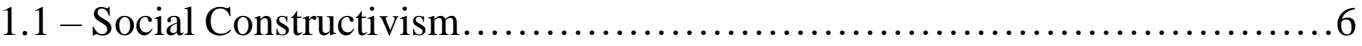

1.2 - Greek Diplomatic Practice............................................23

1.3 - The Development of Panhellenism.................................28

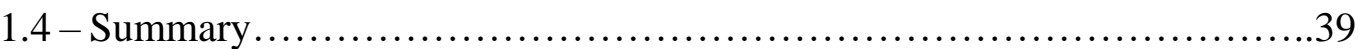

Chapter 2 - Interstate Politics (217-205)

2.1 - Introduction ..................................................... 41

2.2 - Sources Ancient and Modern........................................43

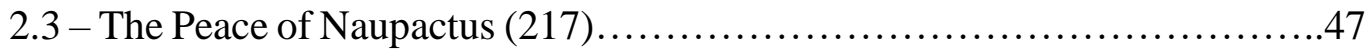

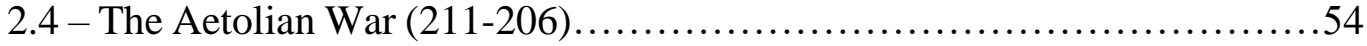

2.5 - Panhellenism and the Mobilisation of Culture............................58

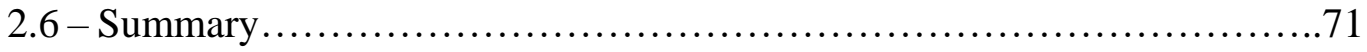

Chapter 3 - The Greeks and Philip V (205-199)

3.1 - Macedonian Aggression and Roman Rapprochement...................73

3.2 - The Resurgence of Anti-Macedonian Panhellenism.....................84

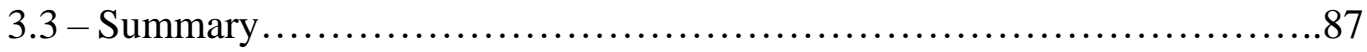

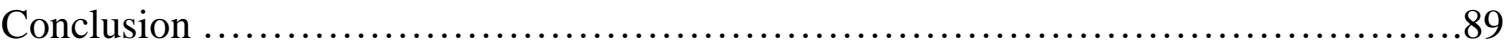

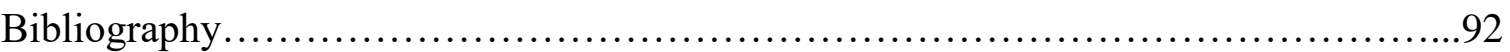

For the title quote: Plut. Vit. Flam. 5.

Frontispiece: G. Sciutu. 1879. Tito Quinto da la Liberta ai greci. Oil on canvas, 83x195cm: public domain. 


\begin{abstract}
International Relations theories colour modern approaches to political history and, hence, to classical studies. Since the Second World War, Realism and Neorealism have been amongst the most pervasive, portraying the international process as something inherently anarchical and self-interested, animated by acontextual variables of power and security. But such approaches leave little room for social, cultural, and ideational variables in the international process; and we know that Greek culture, like others, exerted a powerful influence in the social, political, and economic spheres.

This thesis accordingly uses a more recent IR paradigm, Social Constructivism, to challenge Realism, by accounting for things like rational choice and the role of ideas. It specifically appraises the period of Greek history marked by its early engagements with Rome (217-199), in order to explore the roles of Greek ideas, identities, and agents in animating interstate behaviour. Through this lens, it can be argued that the Greeks' conceptions of interest, whether we deem them to have been upright or cynical, were shaped as much by human variables as by structural ones. Ideas like Panhellenism, barbarism, and the freedom of the Greeks galvanised interstate action; and they militated Greek poleis, federal states, Hellenistic kings, and, later, Roman commanders towards acting (or wishing to be seen as acting) in accordance with popular conceptions of the 'Hellenic' interest.
\end{abstract}




\section{Acknowledgements}

This thesis has been an enjoyable project, owing largely to those who have been there to accompany me.

I am grateful firstly to Jeff Tatum, my supervisor, for agreeing to guide me through the process and for sharing in his expertise. I still remember being floored by the lectures of CLAS105 in 2015 and hoping to one day work more closely with you. I can gladly say that the wait was worth it.

I am secondly grateful to Eilish, my prop and stay. Your support has always uplifted me, and our lifestyle and schedule have been such welcome backgrounds for writing the thesis. You have done wonders to help tackle the complexities of so difficult a year.

Thirdly, I am grateful to my parents, Rhiannon and Brian, and to my brother, Jamie. You are a swell bunch; and I continue every day to reflect on our camaraderie and to try and make good on your endless love and support.

Finally, I am grateful to my friends: to my flatmates, for cracking me up at the end of long days and for enabling the absurd; to my officemates, and to Meg in particular, for sharing in the toil; to Ziming; and to all those of you who know the dearness with which you are regarded.

(And who, by the way, can forget OSRS's midis, or the Jazz Fusion of Haruomi Hosono, the beat and pulse behind my writing process?) 


\section{Introduction}

Especially in the past century, Realist theories have predominated in scholarship about International Relations (IR), animated by a cynical view of human nature which suggests that statism, self-interest, and the desire for power are the primary drivers of international behaviour. The subsequent rise of Neorealism has led to these elements being alternatively seen as something inherent or fixed within the ostensibly anarchical structure of the international system (so called because of the lack of any central organising authority). Such an approach downplays the roles of ideas and rational choice in the international process, suggesting that it is states' material capabilities that determine what they do-not their agents or ideologies. This outlook has likewise found a place in classical studies, pulling accounts of ancient interstate relations towards epistemologies of positivism and natural science rather than towards the cultural turn and the growing field of the social sciences. ${ }^{1}$

The contribution of this thesis is to revisit an important period of ancient history, namely that of the Greek world's first serious interactions with Rome (c.217-199 BCE), and to assess it through the lens of Social Constructivism, a newer theory which critiques Realist and positivist approaches to interstate relations. The result will be to show that the interest of the Greeks was never something wholly material, rigid, or given; rather it was defined, at least in part, by the ideas which came to constitute both their civic and Hellenic identities. Ideas and culture, in other words, shaped the ways in which Greeks conceived of the world around them and became the prism through which they perceived their interests, shaping in turn the way in which they undertook political action.

In tracing the influence of cultural ideas on Greek interstate politics, it is important to prioritise context and, in so doing, to incorporate culture's historical dimension, since "culture, and cultural traditions, are understood as something transmitted from the past". 2 Accordingly, chapter one will show how the Greeks' cultural norms and lived experiences coloured their assumptions about interstate behaviour. Dating back at least to the fifth century, several connected themes recurred to inform interstate attitudes, amongst them philotimia and the desire for the polis to be autonomous; the antithesis between Greeks and barbarians; and Panhellenism or the freedom of the Greeks. As a means of analysing this

\footnotetext{
${ }^{1}$ Implicit: Rosenstein 2012; Waterfield 2014; explicit: Eckstein 2006; 2008. See below for more examples. The cultural turn: Lawson 2006, 17-35.

${ }^{2}$ Lawson 2006, 42. All italics in quoted passages in this thesis have been preserved from the original sources.
} 
complex nexus of Greek ideas and sensibilities, chapter one engages it, chiefly, by way of reference to Alexander Wendt's foundational Constructivist work, Social Theory of International Politics. Thereafter, the nature and institutions of Greek diplomacy shall be analysed. All this will result in two kinds of Panhellenism being described, one positive and one negative on the model of Berlin's Two Concepts of Liberty, whose pervasiveness and relevance to the proceeding chapters shall then be explained.

It will be important to recognise that the truth-value behind appeals to Panhellenic norms need not have any necessary bearing on their capacity to shape interstate conduct: whether honest or not, Greeks often behaved as if they believed in the ideas which they spoke about, and most of these norms were deeply woven into the Greeks' cultural fabric and thus were emotive, fluid, and powerful. ${ }^{3}$ It will be demonstrated that, by the coming of Rome, the Greeks had developed a dense, intricate way of thinking about their relationships with others, both Greek and non-Greek. Additionally, it will be suggested that the Greeks' interstate relations were habitually informed by a nostalgic tradition, which employed both Persian and Macedonian paradigms as distinct mirrors with which to contest and legitimise particular claims to Hellenic identity and, therefore, to the Hellenic interest. With these ideas in mind, chapters two and three will closely trace the years 217-199, the former spanning the period from the end of the Social War through to the end of the First Macedonian War, and the latter spanning the interim period between the First and the Second Macedonian Wars. Chapter one's framework will help to contextualise the behaviours of Greek actors during Rome's entry into the variegated world of Hellenic politics. The importance of this context has too often been diminished by a prevailing interest in the nature of Roman imperialism, or else by a two-dimensional focus on the roles of Greek expediency and interstate violence.

\footnotetext{
${ }^{3}$ On truth-value and the use of norms in a Classical setting: Flower 2000a, 100; Green 2004, 104-7; Low $2007,257$.
} 


\section{Chapter One}

\section{Panhellenism "Is What States Make of It"}

\subsection{Social Constructivism}

Social Constructivism is a recent approach to IR, which seeks in many respects to bridge the gap between Realist and Liberal schools of thought. ${ }^{4}$ Principally, Constructivists believe that it is possible for culture to inform the way states and individuals act at the interstate level. They believe that actors "are socialised into particular forms of international politics", and that their conceptions of interest are influenced both by lived experience and by established norms (nomoi) of interstate behaviour. ${ }^{5}$ Ostwald defines the Greek word nomos as a norm "both in a descriptive and in a prescriptive sense... it is recognized and acknowledged as the valid norm within a given milieu". ${ }^{6}$ Its semantic field is similarly broad, and sweeps from denoting abstract customs to defining hard laws. Hence civil lawmakers are called nomographoi or nomothetai, while Greeks also use nomoi to root certain behavioural expectations within looser, moral frameworks. ${ }^{7}$ In political philosophy, nomos is marked out in point of contrast to physis (nature), where the former describes norms and laws reached through social consensus, and the latter describes those deemed to have been naturally - oftentimes divinely - bestowed. ${ }^{8}$ Questions of normativity and legal right were, in other words, human inquiries, whose answers pertained to the social sphere. It is for a similar reason that Constructivists emphasise the social in politics, and do not believe that interest can be determined through a framework rooted in positivism: "Social science cannot operate like natural sciences", since humans are influenced by intangible factors. ${ }^{9}$ They reflect on their experiences, and their future activities are guided by these reflections.

Insofar as the Greek world was possessed both of a general level of cultural homogeneity (especially when considered with an eye outside it) and a simultaneously high degree of political separation, their interstate arena provides a uniquely compelling atmosphere for

\footnotetext{
${ }^{4}$ Some useful introductions: Adler 1997; Hopf. 1998; Wendt 1999; Guzzini 2000; Christiansen et al. 2001; Björkdahl 2010. Social Constructivism is itself a variegated and diverse field; the first section of this chapter loosely follows Haynes et al. 2011, esp. 212-31.

${ }^{5}$ Haynes et al. 2011, 222.

${ }^{6}$ Ostwald 1969, 21.

${ }^{7}$ Cf. Arist. Ath. Pol. 29.2; Thuc. 8.97.2, each of whom discusses the role of an Athenian board of "lawmakers" in the coup of 411. For Achaean nomographoi: Mackil 2013, 392. On moral frameworks, see below.

8 The hallmark on nomos is Ostwald 1969 (with 2009, esp. 93-172).

${ }^{9}$ Haynes et al. 2011, 214.
} 
testing Constructivist assumptions about behaviour. That constructed norms existed across Hellenic interstate society can often be proven, paradoxically, by the fact that they were broken. ${ }^{10}$ The killing of crews in captured triremes by the Athenians during the battle of Aegospotami, for instance, coupled with their alleged plans to cut off the hands of prisoners, was condemned as barbaric by Sparta and her allies, who deemed that such behaviour transgressed "Greek nomoi" (Hell. 2.1.32). ${ }^{11}$ Similarly, when the Aetolian League arrested two Athenian envoys sent in 367 to announce the sacred truce of the Eleusinian Mysteries, Athens protested (by way of another herald) that the arrest had been undertaken "contrary to the common nomoi of the Greeks" (Agora XVI.48, 13-5; RO 35). ${ }^{12}$ In so doing, they reaffirmed the societal tendency to consider diplomatic personnel to be inviolate. There existed a range of Greek laws and institutions regulating warfare, though some were more influential than others. ${ }^{13}$ And while exceptionable behaviours often emerge in our sources, they also incur condemnation, alongside a reaffirmation of the existence of a recognised set of acceptable forms of interstate conduct.

\section{Identity}

Constructivists, therefore, are interested in the building and maintenance of identities. Sensitive to certain norms and expectations, actors are socialised into roles in interstate relations, which seek to encapsulate their society's values. ${ }^{14}$ Since they often act - or wish to be seen as acting - in a manner appropriate with respect to their role, actors can be found to demonstrate this kind of behaviour regardless of their intentions. Central to the creation of identities (and, thereby, to the importance of culture as a means of constructing them) is the process of othering. ${ }^{15}$ Social-psychological research about group behaviour has shown that the key way groups gain self-awareness of their identities is through discerning insiders

\footnotetext{
${ }^{10}$ Here the unpacking of this idea in modernity (by Haynes et al. 2011, 222) is drawn upon and mapped instead onto the Greek world.

${ }^{11}$ Plut. Lys. 9 suggests it was right thumbs. Diod. 13.104 ff. also treats with this period with some general differences. Low 2007, 59n.91 explains how, despite its debatable historicity, Hell. 2.1 .32 nevertheless remains useful.

${ }^{12}$ This belief was also divinely inspired. On the status of heralds: Berridge 2018, 11-3. We might also consider Thuc. 2.1.1: after the Peloponnesian War broke out, there "were no more communications between the two sides except by way of the heralds".

${ }^{13}$ On the Greek "laws of war" as a meaningful check on state behaviour: Lanni 2008. Cf. Thuc. 5.89. Laws protecting sacred objects and observances were often most consistently enforced.

${ }^{14}$ Haynes et al. 2011, 223-5.

${ }^{15}$ A classic account of the Other, with an eye to east versus west, is Said 1978. See also Wendt 1999, 23940.
} 
and outsiders. ${ }^{16}$ Constructivists have called identities "sticky", for while they are both permeable and prone to reimagination and reproduction, they can also be resistant to change. ${ }^{17}$ The long-recognised example of a Hellenic identity, hardened by opposition to Persian and generically non-Greek 'barbarism', is seen amongst other things to be a central aspect of Panhellenism:

In modern usage 'panhellenism'... refers to the notion of Hellenic ethnic identity and the concomitant polarization of Greek and barbarian as generic opposites which rapidly developed as a result of the Persian invasions. ${ }^{18}$

...arguments for panhellenism depend not only on the qualities of the members of that society, but also on their relationship to those outside: the stability of the society of Greeks, that is, is intimately connected with its opposition (practical as well as theoretical) to non-Greeks' ${ }^{19}$

The invariable corollary of Panhellenism from [490-472 BC] onwards is the maintenance of the image of an enemy common to all Hellenes, the ethnically other, the anti-Greek, the barbarian. ${ }^{20}$

Even in the field of IR, scholars continue to draw from the Greek example:

Enemy images have a long pedigree, and some states continue to position each other in such terms today. The Greeks represented the Persians as "barbarians"...representations of the Other as intent on destroying or enslaving the Self. ${ }^{21}$

In antiquity, the archetypal expression of shared Hellenic feeling is given by Herodotus in a dialogue which, in no coincidence, reaffirms interstate Greek loyalty in the face of Persian encroachment. It stresses simultaneously the Greeks' common blood, cult, language, and ways of life (8.144.2). Moreover, Socrates says in the Republic that "the Greek genos is

\footnotetext{
${ }^{16}$ For example: Abrams and Hogg 2006; Mahadevan et al. 2016; Bruskin 2019; Parashar 2019. Social Constructivists derive this argument from social psychology rather than linguistic philosophy: Haynes et al. 2011, 224.

${ }^{17}$ Haynes et al. 2011, 225.

${ }^{18}$ Flower 2000b, 65.

${ }^{19}$ Low 2007, 60.

${ }^{20}$ Hall 1989, 60, who goes on to discuss Aeschylus' Persians.

${ }^{21}$ Wendt 1999, 261.
} 
friendly and akin to itself and foreign and alien to the barbarian", illustrating how this common identity was often emphasised by its contrast to non-Greeks (Rep. 470c1-2). ${ }^{22}$ That such a binary was elsewhere sustained in vase-painting and drama, at (oftentimes Panhellenic) assemblies, and in public dedications at temples offers a suggestive indication that this kind of Other construction was not limited only to intellectual circles. ${ }^{23}$ The cultivation of a Hellenic identity, extant beforehand but made explicit through a collective moment of external shock during the Persian invasions of 490 and 480, framed the way in which Greek states subsequently managed affairs amongst themselves, hardening certain norms and prejudicing particular conceptions of interest. Thereafter, it transformed the paradigms according to which Greeks perceived of peripheral states like Macedon and, later, Rome.

\section{Interstate Politics and Panhellenic Identities}

By focusing on the chaotic and disorderly outside, Greeks had an outlet with which to mollify inherent conflicts on the inside. In this way, the apparent unity of the Greek world could be exaggerated. The political outcomes of such a perspective were, at least initially, obvious in the case of the Hellenic League of 481. Herodotus wrote that "at a conference of the Greek states who were concerned for the general safety of Hellas, guarantees were exchanged, and the decision was reached to reconcile their hatreds and wars between one another", in order to better prosecute the war against Xerxes (7.145.1). Put differently, Greekness (to Hellēnikon) was not, as it became in the face of Ottoman rule, an explicit aspiration to nationhood; but it nevertheless outlined a place, delimited a group beyond the level of the state, emphasised its common ethno-cultural qualities, and brought about a political alliance- helped in no small part by the identification of an exogenous and ostensibly common threat in the form of the Persian Other. ${ }^{24}$ Hence, and especially in the aftermath of the Persian Wars, Mitchell has this to say about the Greek phenomenon of cultural politics:

\footnotetext{
${ }^{22}$ Socrates further differentiates (Rep. 470b) between Greeks and non-Greeks by referring to "the friendly and the kindred on the one hand" and "the foreign and the strange on the other", the polarity emphasised by a $\mu \grave{\varepsilon} v . . \delta \dot{\varepsilon}$ construction.

${ }^{23}$ Contra Perlman 1972. Vase-painting: Miller 2005; drama: Hall 1989. Aeschylus' rapid publication of the Persians in 472, while being the clearest, is by no means the only example; Panhellenic assemblies: cf. the Olympic orations of Lysias and Gorgias. In Athens, see Dem. 9.28-36 and, generally, in Isocrates' Panegyricus and Panathenaicus (with Flower 2000b, 92-3; Low 2007, 58); dedications: Miller 2005, 109; Flamininus makes use of sanctuary dedications in the second century: Plut. Flam. 12.6.

${ }^{24}$ On modern Greek Panhellenism, with reference to ancient Greece: Dimaras 1992, 203-24.
} 
the 'Hellenes' as a self-conscious community was more than just a Kulturstaat, a community of shared culture. The 'community' of the Hellenes existed at the level of the imaginary and the symbolic. The Hellenes existed because the Hellenes said they existed; as a result, it was also a 'political' community with a self-consciously shared identity. The Hellenes imagined their community into being because the 'idea' of 'the Hellenes' was recognised as one which carried power, that is, it was an idea that was necessary to the selfinterest of the group. ${ }^{25}$

Indeed, the reimagination of the Persian Wars often lent on its political dimension. So Simonides' famous epitaph celebrates the three hundred's obeisance to their polis and to civil law (Hdt. 7.228). ${ }^{26}$ And in continuing to profile the east as the antithetical Other, the Greeks stressed the superiority of their constitutions (politeiai) over against that of the Persian monarchy. ${ }^{27}$ Persia became a paramount symbol of tyranny and, therefore, of political slavery. ${ }^{28}$ And according to this conception, success in warding off the Persian Empire owed itself not to advances in technology or military strategy, but to the Greeks' free status, and to the concern which they shared for the good of their communities. The natural corollary of such an explanation was an innovation in the Greeks' concept of freedom. Formerly, eleutheria served chiefly as the designation of an individual's sociolegal status. ${ }^{29}$ Throughout and after the wars, however, freedom was transferred to describe the condition of the community at large. By enshrining the Persian Wars within a grammar of Panhellenic victory, both the community in question and its attendant freedom unilaterally stretched to cover all Hellas; and this conceptual reverence for a Panhellenic kind of eleutheria hereafter remained a fundamental component of Greek diplomacy, all the way until 146 and beyond the period of Roman domination.

\footnotetext{
${ }^{25}$ Mitchell 2007, 3. Some twenty-first century studies: Flower 2000a, 2000b, Hall 2002, Low 2007, Mitchell 2007, Vlassopoulos 2013. On the idea of symbolic community, consider Mitchell 2007, 2: “As Stuart Hall notes for the modern nation-state: 'People are not only legal citizens of a nation; they participate in the idea of the community as represented in its national culture"".

${ }^{26}$ The values enshrined in this monument have had a notable influence on ideas of 'western civilization', as seen for instance in Ruskin 1894, 212.

${ }^{27}$ Mitchell 2007, 77-104, Vlassopoulos 2013, 61.

${ }^{28}$ Mitchell 2007, 24-6.

${ }^{29}$ Vlassopoulos 2013, 60, with Raaflaub 2004, 58-98. Dmitriev 2011's survey of Greek freedom takes as its starting point the Peloponnesian War, but does not mention the Greeks' use of freedom earlier in the fifth century.
} 
This phenomenon also manifested in the practical sphere. The emergence of the Common Peace (koinē eirenē) as an influential political concept in the fourth century shows, for example, that the Greeks came to recognise the need to consider all parties when settling interstate conflicts. There were several attempts at this: in 387/6; 375; two in 371; in 368; in 366 ; in $362 / 1$; and in $338 / 7 .{ }^{30}$ Each treaty was multilateral, imposing obligations on all poleis (even though they did not always participate as signatories), and they created a soft kind of interstate structure. ${ }^{31}$ The idea of common peace encapsulated the idea of common freedom, implying one the one hand "peace among all Greeks", and on the other "their joint action against common enemies". ${ }^{32}$ Individual states and rulers, however, were usually inscribed as sponsors of each peace, and so the current hegemonic power could continue to legitimately sustain a pre-eminent role within the purview of interstate 'law' ${ }^{33}$ All this led Perlman to characterise Panhellenism as a "basically negative" ideal, in the sense that its central component was not in fact common unity, but rather the antithesis between Greeks and other "nations". ${ }^{34}$ The free political status of the Greeks was defined by opposition to theoretical (the notion of autocracy) and practical (the invasions of 490 and 480) elements of Persian power, and so Panhellenism could become an outlet through which to animate interstate competition amongst the Greeks themselves:

The Panhellenic ideal served as a tool of propaganda for the hegemonial or imperial rule of a polis; it served to justify the hegemony and the mastery of one polis over other states by proposing a common aim, war against the barbarian. It was the transformation of the Panhellenic ideal into a political concept after the Persian wars which made this use of it possible. ${ }^{35}$

The Athenians, for instance, thought their gloried role in the Persian Wars gave them legitimate grounds to assume a role of Panhellenic leadership over other poleis. Though he thought it would be "displeasing for most" for him to say so, Herodotus claimed the Athenians exerted the greatest spirit in defending Greece (7.139); and Thucydides later put

\footnotetext{
${ }^{30}$ Eckstein 2006, 41.

${ }^{31}$ Low 2007, 66. For assessments of each Common Peace: 387/6: 44, 110, 189, 192-7; 375: 66; 371: 109, 185; 362/1: 106. Low does not include the settlement of Philip II amongst her catalogue. That not all poleis signed: Badian 1991, 39-40.

32 Dmitriev 2011, 66.

33 387/6: Artaxerxes I; 375: Athens; 371: Sparta and then Thebes. The peace of 362/1 had no single sponsor. On the 'problem' of the Common Peace: Dmitriev 2011, 54-66.

${ }^{34}$ Perlman 1976, 3, with Hornblower 1991, 13; Green 2004, 105; and Mitchell 2007, 10-9.

${ }^{35}$ Perlman 1976, 5.
} 
similar words in the mouths of Athenian ambassadors in Sparta (1.74, cf. 5.84-116). ${ }^{36}$ After the Persian Wars, the Hellenic League gave way to the Delian League which, through a consensus of its members, propped the Athenians up to inherit Sparta's traditional prostasia in Greece. Their leadership "commenced with independent allies who acted on the resolution of a common congress" (Thuc. 1.96-7). Isocrates asserted that this legitimate power transfer was evidence of recognition by other states of Athens' contributions in the Persian Wars, and that they were therefore widely deemed to have been deserving of a hegemonic role $(12.49-52,14.59) .{ }^{37}$ In keeping with the Panhellenic line, the Delian League cited deriving profit by attacking Persian lands as its foundational objective; and indeed, especially while under the leadership of Cimon, it was initially successful at dislodging Persian garrisons from Greek cities in Thrace and along the Ionian coast. ${ }^{38}$ Nevertheless, the Delian League is generally seen to have mutated into a vehicle of Athenian hegemony over the course of a few decades. And for much of the twentieth century, Herodotus was believed to have been an encomiast or partisan of Athens, and his accounts of Athenian success in the early fifth century came under scrutiny for being uncritical or apologetic, taking their Panhellenic line too much at face value. ${ }^{39}$

Moreover, though perhaps counterintuitively, kinship ties and myths of autochthony served as further loci around which claims to primacy could be asserted, as Fragoulaki has recently shown. ${ }^{40}$ While the Athenians stressed their connection to other Ionian Greeks, they set themselves apart from them by stressing their pure-bloodedness and primordial connections to Attic land:

In fact, [autochthony] worked quite well, because it detached them from the traditional concept of Ionian feebleness, which was too engrained to be shifted, and justified their supremacy over their

\footnotetext{
${ }^{36} \mathrm{Cf}$. the remarks of Pericles in the funeral oration about Athenian valour in the face of Hellenic and foreign aggression (Thuc. 2.35).

${ }^{37}$ Mitchell 2007, 83-4.

${ }^{38}$ The confederal reputation of the early league has often been suppressed at the expense of the later, more explicitly imperialistic one. Beyond activities in Thrace and Asia Minor, the league won a decisive battle at Eurymedon river, shortly after which Xerxes was assassinated. On these successes and the use of a campaign of Panhellenic ideology: see Flower 2000b.

39 This conclusion is now being reassessed. See in particular Evans 1979, 112-8; and Balot 2001, 108n.20.

${ }^{40}$ Fragoulaki 2013, 209-27.
} 
colonists not only as mother-city, but also as a unique one... On the interstate level, the claim of uniqueness was all but isolationist. ${ }^{41}$

It is easy to see how corollary aspects of identity slid into the political sphere. The role of Athens-as-refuge, signposted in the Archaeology of Thucydides' history, foreshadows the later remarks of Pericles and Alcibiades, each of whom publicly celebrated Athens' readiness to help others in need - even those who had never assisted her, or who lay outside of the alliance (Thuc. 2.40, 6.18). Such ideology smacks of interventionism, which in modernity constitutes a violation of international law. ${ }^{42}$ And yet, the Greeks utilised the language of "helping the wronged (boèthein tais adikoumenais)" to frame interventionism as a kind of ideal. ${ }^{43}$ Demosthenes considered it to be a universal and positive norm of Hellenic behaviour $(2.24 ; 9.23-4 ; 16.14-5) .{ }^{44}$ Outside Athens, we can see Agesilaus at an interstate summit espouse 'justice for the wronged party' as the motivation for Sparta's intervention at Phlius in 380 (Hell. 5.3.14). Disputes and treaty settlements were everywhere configured around a vague, moralising framework of praise and blame, all culminating in a curious dichotomy whereby states like Athens, Sparta, and Thebes continued to cooperate and cultivate ties with other Greeks while simultaneously propagating self-images of exceptionalism and supremacy.

This well encapsulates the Greek relationship to philotimia - ambition, or love of honour. It was a desirable quality for states seeking to assert themselves as 'First' amongst the Greeks, but a detestable one for those who suffered at their expense. Osborne says that the Greeks had a 'love-hate' relationship with philotimia, powerfully animated by selectivity and ambivalence. ${ }^{45}$ And as always, the spectre of Persian, and indeed intra-Greek, tyranny remained on hand to harden images of the Panhellenic 'We' and to imbue lesser poleis with feelings of dependency on the hegemon. Even when they entered the fourth century weakened and defeated, for instance, Athenian ambitions remained to revive their prestige

\footnotetext{
41 Fragoulaki 2013, 209-10; 221. On the importance of Euripides Ion and the funeral oration genre in propagating Athens' autochthonous and Ionian traditions: 220-4. For the political function of these themes in funerary speeches: Loraux 1986, esp. 77-131, 221-262. For more on autochthony, Ion, and Ion: Hall 2002, 203-5.

${ }^{42}$ So UN resolution 2625: a 'Declaration on Principles of International Law concerning Friendly Relations and Co-operation among States in Accordance with the Charter of the United Nations', with Klabbers 2016, $362-375$

${ }^{43}$ On the Greek 'Problem of Intervention': Low 2007, 175-211.

${ }^{44}$ The theme is also prevalent in the works of other Attic orators: so the Lysianic epitaphios 2.8, 13-4, 22 , 67-8; Isoc. 6.31.

${ }^{45}$ Osborne 1993, 35. Ambivalence to philotimia and 'First' amongst the Greeks: Mitchell 2007, 82-5. See also Tatum 2013, 446.
} 
"in the only way they understood", that is, with a second league, and with a revival of the claim that Athens was synonymous with Greekness, with Panhellenism, and with freedom from external tyranny. ${ }^{46}$

Although the Athenians perhaps offer the best evidence, it is important to note that they were not exclusive in making these kinds of Panhellenic claims. Corinth, for instance, sought to take credit for the Greek naval victory at Salamis in $480 .{ }^{47}$ And despite pursuing an isolationist policy after the Persian Wars, the Spartans felt entitled to retain their position of Panhellenic leadership, having served as the undisputed leaders of the Greek alliance at the Battle of Plataea (Hdt. 9.22.3, 45-6; Thuc. 1.18.2). ${ }^{48}$ Their waging of the Peloponnesian War was, in the view of Thucydides, a product of their anxieties about losing that leadership (1.88). At Acanthus in 424, Brasidas speaks of "liberating Greece" from the Athenians and seeking by Sparta's conduct to gain time in the eyes of the Hellenes (Thuc. 4.86-7). Similarly, after the Battle of Aegospotami in 405, Lysander and his Peloponnesian allies acted as moral arbiters in sentencing Philocles and his fellow Athenians to death for their transgressions of Greek nomoi, seeking to alienate Athens from the rest of the Greek world (Xen. Hell. 2.1.32). After Thebes and the Boeotian League then upturned Sparta's hegemony at Leuctra in 371, Epaminondas in turn invited Athens to join them in attacking Laconia, to "make the Spartans pay" for all that the Greeks had suffered at their hands (Xen. Hell. 6.4.19). ${ }^{49}$ In the following years, Xenophon relates that Pelopidas directed all Theban policy towards the establishment of their own supremacy over Greece (7.1.3140). ${ }^{50}$ So we see a revolving network of states competing for excellence, their interactions guided on the one hand by philotimia, and on the other by phthonos, and by anxieties about the success of others.

To be sure, "the Hellenes" was not the only, nor indeed the most important, identity available to the Greeks. The notorious particularism associated with the polis retains the inevitable pull, not least because the polis was the principal model around which the Greeks' conceptions of civic life were informed. On the surface, the interventionist

\footnotetext{
${ }^{46}$ Green 2004, 119.

${ }^{47}$ This they did through the contributions of their general, Adeimantus: Mitchell 2007, 83.

${ }^{48}$ Ehrenberg 1960, 107, 112. On Spartan prostasia: Lendon 1994, 159-77.

${ }^{49}$ Cf. Xen. Hell. 3.5.4-15. See also Low 2007, 69-72. On the role of the Boeotian League in and around the Battle of Leuctra: Mackil 2013, 71-2, 207-10.

${ }^{50}$ This period includes a fascinating and subversive series of embassies from Thebes, Athens, and Sparta to Artaxerxes, in which the Thebans invoked their role in the Persian Wars as collaborationists and Medisers in order to justify why they deserved support from the Great King over against their competitors.
} 
ideology of the greater Greek powers may seem at odds with their isolationist ones. As Pericles' funeral oration makes clear, however, Athenian readiness for helping other Greeks had aggrandising effects on her self-esteem (Thuc. 2.34-46). In this way, Panhellenic sentiments affected behaviour inside the civic sphere at well as outside of it. Notwithstanding the truth-value behind certain actors' appeals to Panhellenic themes, a community's moral or religious sentiments could not in the first place be deployed to political advantage unless they echoed, on some level, a principled commitment on the part of those being manipulated, or else captured a real sense of public outcry when those sentiments were said to have been violated. ${ }^{51}$ However quixotic or unattainable it may have been in reality (as is the case, Green notes, with eleutheria), Panhellenism was evidently still an ideal for many people. "Hellas remained a place", Green suggests, dubbed a common fatherland (koinē patris) by Isocrates and Diodorus (Isoc. Paneg. 81; see also Philip 127; Diod. 18.10.3). ${ }^{53}$ The belonging of groups to that place was ritualistically acknowledged by Panhellenic games, which themselves implemented regular cessations of Greek conflict. ${ }^{54}$ Sanctuaries and shrines, furthermore, continued to enjoy inviolable protections; and Ephorus' universal History of Greece suggests that it remained the popular outlook to both recognise and distinguish the Greek from the Other - as with the Herodotean description - on the bases of common culture and common aspirations. ${ }^{55}$ Balot asserts that, “Mutatis mutandis, classical Greeks accepted a brand of Cicero's restricted cosmopolitanism, according to which we have special obligations to our city-states, which coexist with thinner obligations to those of the same "nation," and still thinner obligations to humankind generally (Cic. Off. 1.50-8)" ${ }^{56}$ This concentric arrangement of obligations is a framework familiar to Constructivists, as we shall see in a moment.

States and individuals can be found at all points in Greek history to have acted in violation of their normative and cultural expectations in interstate society. But it does not follow

\footnotetext{
${ }^{51}$ Green 2004, 106-7.

52 Green 2004, 107, who adduces Ov. Met. 7.20-1: “aliudque cupido, / mens aliud suadet, uideo meliora proboque, / deteriora sequor".

${ }^{53}$ Green 2004, 107.

${ }^{54}$ Berridge 2018, 12. Sparta's failure to adhere to the ban in 420 (Thuc. 5.49; cf. 8.9-10), Green 2004 points out (107), resulted in "firm exclusionary measures" being taken at their expense; cf. Malkin 2011, 13, who urges that, in the archaic period and especially in terms of their broad distribution around a Mediterranean oceanic centre (so Plato's 'frogs around a pond' metaphor in Phaed. 109b), the modern, national issue of collective identity as bound up with a national territory is not so much something that the Greeks dealt with. ${ }^{55}$ On Ephorus: Luce 1997, 109.

${ }^{56}$ Balot 2006, 145. Though a later invention, the concentric model of cosmopolitanism expounded by the Stoic philosopher Hierocles demonstrates how loyalties could be complicated and interrelated by variable levels of relationship or obligation (Stob. Flor. 4.671). See also Long 2008.
} 
from this that Hellenic norms, identities, and ideas played little to no role in affecting the ways Greeks arrived at policy or created particular contexts or "cultures" of meaning in interstate relations. ${ }^{57}$ Green must be correct in saying that the Panhellenic ideal constituted a "more ambiguous, influential, and emotionally complex" cultural paradox than is sometimes suggested by "black-and-white essay[s] in Realpolitik". ${ }^{58}$ The ideal slipped into the behavioural sphere of Greek international politics in ways which are either liable to being downplayed, or else taken for granted by certain Realist assumptions-especially those which pertain to definitions of self-interest. Contesting the Realist notion that states are self-interested by nature (as opposed to sometimes or even most of the time), Alexander Wendt, a prominent Social Constructivist, states that:

\begin{abstract}
All other things being equal, the international system contains a bias toward "Realist" thinking. The question, however, is not whether there are pressures on states to be self-interested - there are - but whether states are capable ever of transcending those pressures and expanding the boundaries of the Self to include Others. This they might do initially for self-interested reasons, but if over time the identification becomes internalized, such that a group of states learns to think of itself as a "We," then its members will no longer be self-interested relative to each other with respect to the issues that define the group. The question, in short, is whether the members of states can ever learn additional "social" (what I am calling "collective") identities above and beyond the state, creating "concentric circles" of group identification. 59
\end{abstract}

The grammar of such a question rebounds to Balot's description of the restricted cosmopolitanism of Classical Greece, something which only relaxed as the Hellenistic period dawned and expanded the criteria for acquiring a "Hellenic" identity. Poleis in the Hellenistic world are found to have innovated the traditional patterns of public life, whether to attain greater security or to incorporate changing civic values. ${ }^{60}$ Obligations to the city-

\footnotetext{
57 "Cultures", especially pertaining to international anarchy: Wendt 1999, 246-312.

${ }^{58}$ Green 2004, 105, who is also aware of the modern tendency (106): "Academics and writers have always had a marked tendency to see all politicians as consistently mendacious and self-seeking Machiavellians, tout court; yet even a slight acquaintance with the actual world of politics should suffice to modify such a stereotype".

${ }^{59}$ Wendt 1999, 242.

${ }^{60}$ Walbank 1981, 141-59.
} 
state became shared with those of the ethnos or sympoliteia, and states negotiated extensively to bring about agreements which ensured common protections and legislated against interstate violence. ${ }^{61}$ Many of these civic characteristics, as Walbank points out, were not new, but traced more or less directly through the fourth and fifth centuries, simply acquiring new significance in the Hellenistic atmosphere. ${ }^{62}$

In its wake, the campaign of Alexander the Great had left a diaspora of Greco-Macedonian elites who oftentimes supplanted local structures and networks. Insofar as this kind of cultural imperialism (often inadvertently) creates two-way exchanges, the categories which defined being Greek became porous and more pliable. ${ }^{63}$ Hellenic identity opened up, in other words, with its more primordial, ethnic, and genealogical claims receding in the wake of an increase in constructivist ones — of claims to Hellenism as acquired through education or paideia ${ }^{64}$ Hence for many in the Hellenistic period, Hellenism became something of way of thinking and acting, rather than a simple indicator of one's ethnicity. This ought not to suggest too rosy a picture: identities, we have seen, are sticky; and the growth of constructivist claims to Hellenism indicates a process of dualism and overlapping, not one of outright replacement. In the Hellenistic context, perhaps more so than in the Classical, philotimia and allegiance to the polis or sympolity caused flares of philoneikia contentiousness, or an obsession with strife - throughout the Greek world. ${ }^{65}$ Fear, violence, and passion continued to bear significantly on the conduct of interstate politics. Social Constructivism does not necessarily reject the logic inherent in Realist (or Liberal) models of interstate behaviour - it is, after all, in many respects a metatheory - but it routinely distorts it.

\section{Society versus System}

Constructivists do not, therefore, dismiss the Realist idea (seen, for instance, in the works of Arthur Eckstein) that Greek or Mediterranean society was anarchic, multipolar, and lacking in a hegemon or clear system of international law. ${ }^{66}$ It does, however, try to offer more nuanced and context-specific pictures of the hierarchical relationships, institutions,

\footnotetext{
${ }^{61}$ Mackil 2013, 91-146.

${ }^{62}$ Walbank 1981, 141.

${ }^{63}$ So Champion 2004, 39. On Greek cult sites and sanctuaries as spaces for cultural interchange: 39 n.36.

64 'Primordialist' and 'constructivist' claims to Hellenism: Champion 2004, 40. For a detailed study of the growth of Hellenism and homogeneity in the Hellenistic period: Walbank 1981, ch. 4.

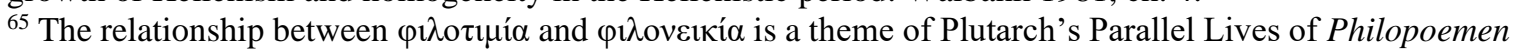
and Flamininus: Tatum 2013, 446.

${ }^{66}$ So Eckstein 2006; 2008; and, overall, Waterfield 2014. On the anachronistic hazards entrained in Realist models of ancient anarchy: Wendt 1992.
} 
and laws that obtained across various interstate societies. Wendt argues, for instance, that since anarchy is an especially broad category, one should be alert to the distinctions inherent across different systems which are described as "anarchic". The modern international system and the Greek interstate system may both be characterised as anarchies, for example, and have even been compared on this basis; so political science concepts like the so-called "Thucydides Trap" build assumptions out of a direct comparison of Athens-Sparta and US-China tensions. ${ }^{67}$ But each system is distinguished by several clear and important differences. The former system, firstly, is a global one, which contends with existential pressures like nuclear proliferation. The latter system, by contrast, not only exists within a restricted cultural environment (with, it is true, its own inherent distinctions) but is also surrounded by additional systems, which both coexist and interfere with it. Wendt accordingly believes that actors in any given anarchical environment produce variable "cultures" of anarchy, which are shaped both by the particulars of an actor's context and by their norms and interactions with others. ${ }^{68}$ Anarchical structures are fluid and wide ranging because they are presupposed by agents, who reproduce perceptions of anarchy in different ways and according to different contexts.

The tendencies of modern political scientists to focus on ancient Greek anarchy and to compare it with contemporary society appear, to some extent, to be a legacy of Thucydides' reputation as the father of political Realism. ${ }^{69}$ But a fair way to treat the restricted Greek system as a parallel to the global modern one, in the interests of consistency and scale, would be to see the Greeks' interstate ethnic, religious, and federal institutions as possessing similar functions to contemporary supranational authorities. Liberal theorists, for instance, point to modern institutions like the European Union, United Nations, or World Trade Organisation as examples of such authorities, which legislate above the state level and induce at least a part of the international system towards common interests and common behaviours. ${ }^{70}$ Similarly, in European Greece by the end of the fourth century, nearly half the poleis had become members of federal states. ${ }^{71}$ Those which were most

\footnotetext{
${ }^{67}$ The Thucydides Trap: Allison 2017; see also Kauppi 1991, with Korab-Karpowicz 2006 and Haynes et al. 2011, esp. 223. See also Lebow 1991; Eckstein 2006; 2008.

68 This is the gravamen of the "cultures of anarchy" theory of Wednt 1999, 246-312.

${ }^{69}$ See Kauppi 1991; Korab-Karpowicz 2006.

${ }^{70}$ On the structural similarity of the lateral, decentralised networks of ancient Greece and the European Union: Malkin 2011, 13.

${ }^{71}$ Mackil 2013, 1. Reducing explanations of behaviour in Greek koina to singular, statist assessments of interest, especially by way of an argument of analogy with the USA, is hazardous. The Founders' interest in Polybius and the Greek leagues culminated in a rejection of weaker league organisation in favour of greater American unilateralism, and a set of institutions resembling a more centralised body like the Roman Republic.
} 
influential - the Aetolian, Boeotian, and Achaean Leagues - each comprised several dozen poleis, whose federation and horizontal institutions stood in juxtaposition to the lack of those in many adjacent kingdoms, tyrannies, and oligarchies. ${ }^{72}$ These states united poleis under common citizenship (sympoliteia), enforced trade regulations, and superimposed legislation above the level of the local laws independently preserved by member states. ${ }^{73}$ Mackil has drawn on federal economic institutions to show how Hellenistic poleis pooled risks as well as resources, acquiring not just new advantages but new obligations. ${ }^{74}$ Other super-state organisations also existed to protect Hellenic religious and cult institutions in the form of amphictyonies. The Delphic Amphictyony is perhaps the best known but is by no means the only example: it legislated and acted against cutting off water supplies during wartime and prohibited the razing of poleis belonging to other members (Aesch. 2.1147). ${ }^{75}$ Further, as has been discussed, Common Peace legislation provided another outlet for interstate structure in the Greek world, but possessed troublesome elements, namely in that not all states were officially inscribed as signatories and insofar as their terms sometimes served to enshrine the current hegemon's power.

While indeed most ancient associations were not holistically inclusive with respect to the Greek anarchical system, neither today is the European Union a holistic authority with respect to the globe, and nor initially was the United Nations; yet these bodies succeed in considerably affecting system dynamics and regulating global behaviour. Like modern nation-states, individual poleis visibly continued to cherish their autonomy, and the stickiness of their autonomist identities tended to be exposed when confronted with restrictions like the federal compromise. ${ }^{76}$ "The Greek koinon was not, then, a unitary state", Mackil asserts, even if they are treated by scholars as one, since the political power of member poleis was "never more evident than when it was used to check abuses of federal

The principle concerns of Federalist 9, 10, and 18 were that the Greek leagues were insufficiently unilateral, affording too much room for state anarchy. Federal influence, moreover, was abundant in the fifth and fourth centuries, even if scarcely recognised by scholarship (see in particular Mackil 2013, 4; 21-90). Several political scientists (such as Kelemen 2005: see esp. 1n.2), moreover, consider it a given value of modern bodies such as the EU that they are themselves federal systems.

72 Grainger 2017, 11. For more on the Achaean and Aetolian Leagues, see Larsen 1968 and Mackil 2013. The Achaean League and tyranny: Mackil 2013, 103.

${ }^{73}$ Mackil 2013 is a model work on ancient federalism. On sympoliteia: esp. 5, 359-62; on trade: 237-325; on institutions and federal law: 326-99.

${ }^{74}$ Mackil 2013, 246.

${ }^{75}$ On the Amphictyony's importance during Sacred Wars (esp. the Third), see Buckler 1996, 79, 90-1; Mackil 2013, 83-4. The context in which Aeschines invokes the Delphic Amphictyony's oaths is persuasive evidence that they were not simply token.

${ }^{76}$ On the federal compromise, esp. in ancient Greece: Mackil 2013, 393-6, 402-3. 
power" ${ }^{77}$ One cannot say that such an institution failed to regulate interstate behaviour, or else to make a citizen's conception of identity a multifaceted one. Inasmuch as Realists consider the state to be the basic unit of international relations, they can be prone to conflating the various identities of Greeks, say, in Achaea and Aetolia, or even elsewhere in Boeotia, Epirus, Thessaly, Crete, or Asia Minor - each location federated at some stage during the Classical and Hellenistic periods. Economic, religious, and federal organisations imposed a series of obligations often distinct from those of the still self-governing polis. As is especially shown by the healthier body of evidence available in leagues of Achaea and Aetolia, this necessitated the maintenance of a twofold identity amongst citizens, as members of the polis on the one hand, and of the federal state (koinon) on the other.

\section{Interest and the "Distribution of Ideas"}

These institutions above the level of the city-state complicate an already contentious issue of determining what it is that constitutes interest, something which Realists tend to present as being somehow self-evident. ${ }^{78}$ At its root, Realism propagates a cynical and rigid view of human nature where actors are inherently selfish, fearful, and hostile. Neorealism, moreover, considers the state of anarchy to be a natural, given fact of international structure. Constructivists can see that the conditions like systemic anarchy define behaviours of states, but only insofar as that system's agents evince the belief that their society is anarchic, or else characterised by poles of conflict and enmity rather than peace and friendship. Constructivists adhere foremost, in other words, to a thin theory of rational choice: structural processes and cruel self-help worlds are shown to exist and influence behaviour where agents are shown both to believe in and act on the basis of them. ${ }^{79}$ This opens up the motivations of actors to a broader range of explanations, and it is here that defining self-interest becomes a point of contention: through a Constructivist lens, nontrivial discussions of interest depend on the insights and identities of the agents in question. Hence, Wendt's definition of interest returns to the maintenance by groups of a cognitive distinction between Self and Other:

Thin rational choice theory does not take a stand on the content of actors' desires or beliefs...Realism, however, does take a stand:

\footnotetext{
${ }^{77}$ Mackil 2013, 399.

${ }^{78}$ Haynes et al. 2011, 223 and 230: "for Social Constructivists, the national interest is a category that needs to be explained, rather than being treated as an explanatory factor".

${ }^{79}$ Wendt 1999, 367-9.
} 
whatever states are up to, it must be out of self-interest. Realism is one thick theory of state interest. ${ }^{80}$

For the concept of self-interest to do any explanatory work it must be defined as a kind of interest, which means rooting it in a conception of identity. We cannot understand self-interest, in short, without understanding the Self, and especially its relationship to the Other. $^{81}$

As well as exposing the tautological character of phrases like "the actor did $\mathrm{X}$ because $\mathrm{X}$ was in their interests", this definition reveals the ways in which Realist explanations of interest build in cultural factors, whilst denying or marginalising their impact-a phenomenon to which we shall return in later chapters. With an institution like federalism, we have seen a way in which Realism's commitment to state self-interest poses difficulties for defining interest in contexts where the state unit is blurred. Even looking within the polis - the concentric circle with perhaps the thickest level of obligations - citizens struggled to reconcile civil strife or factionalism (stasis). Thucydides reports that during the Peloponnesian War stasis had pervaded so many cities that only Sparta, owing to its 400-year old constitution, managed to avoid it (1.18.1). ${ }^{82}$ So prevalent both in the fifth century and after, factionalism offered yet another outlet through which the traditional state-unit could be made ancillary, and thus our understanding of its objective interest hard to untangle.

To further complicate matters, there are examples of Greeks conceptualising of stasis as a force operating at the Hellenic level. Theognis and Herodotus both use stasis to describe wars between Greeks states (Thgn. 781; Hdt. 8.3); and recent scholarship argues that, at large, Thucydides conceptualised the Peloponnesian War as a stasis emphylios, or "civil war" between all Greeks - the obverse of the Common Peace ideal. ${ }^{83}$ The type of stasis

\footnotetext{
${ }^{80}$ Wendt 1999, 368.

${ }^{81}$ Wendt 1999, 240.

${ }^{82}$ Explicit instances of civic stasis and its potential outbreaks in this period include (and are by no means limited to) Mytilene (Thuc. 3.2-350), Corcyra (3.69-85), Athenian tributaries in Thessaly and Thrace (4.7888), Scione (4.120-3), Leontini (5.4), Argos (5.82), Syracuse (Thuc. 6.33-40), Samos (8.21), Rhodes (8.44), Athens (8.64-9), and Samos again (8.72-8). Lysias claims (2.56) that Athenian leadership saved her allies from stasis and despotism. For more on stasis generally, see Lintott 1982, 92, Fuks 1984, 250-6, 270-82, Low 2007, 131, 164, and Gray 2015.

${ }^{83}$ So Price 2001, Low 2007, esp. 54-77, 131, 162-4, 222-33, and Gray 2015, 200-3. Stasis emphylios stresses elements of ethnicity and kinship: Cartledge 1995, 77. On the coexistence of Realist and Idealist paradigms in Thucydides, consider Gray 2015, 203.
} 
omnipresent throughout the war, powerfully captured in Thucydides' vivid account of Corcyra in 427, elevated the civic experience into a defining struggle for Hellas, divided "within cities as well as between them, into democrats (who favour Athens), and oligarchs (who favour Sparta)" ${ }^{84}$ For this reason Thucydidean stasis has been called "multilateral", since factionaries struggled everywhere and according to the same objectives. ${ }^{85}$ Low opts to call these pro-Athenian and pro-Spartan factions "interstate societies", since they were perpendicular groups whose membership was determined by political ideology rather than citizenship. ${ }^{86}$ Naturally, therefore, in works of fourth-century political philosophy, Hellenic invocations of stasis began drawing on the periphery once again:

We shall then say that Greeks fight and wage war with barbarians, and barbarians with Greeks, and are enemies by nature, and this enmity should be called war. Greeks, however, we shall say, are by nature friends of Greeks even when they act in this way, but that Greece is sick in that case and divided by stasis, and stasis is the name we must give to that enemy.

Plat. Rep. 470c5-d1 (trans. Low 2007).

There are a handful of ways in which interests and identities typically explored through the lens of the polis can simultaneously be seen to transcend the "city-state culture". ${ }^{87}$ Wendt asserts that they are conditioned not just by material forces, but by discursive formations and "the distribution of ideas in the system". ${ }^{88}$ Panhellenism is not necessarily an impulse more authoritative than polis loyalty, and nor does it push the variable of Greek ideas somehow beyond those of power and interest; but they cannot be viewed as operating separately of one another. In short, a Wendtian form of Social Constructivism sees the traditional "ideas-versus-interests" debate as presenting an incomplete picture: power and

\footnotetext{
${ }^{84}$ A powerful summation of Thuc. 3.82 .1 by Low 2007, 54. See also Lintott 1982, 90-1. On the ideological conflict between democracy and oligarchy: Balot 2006, 86-91. It has been debated (even in antiquity) whether Thucydides' description accurately described a phenomenon in Greek politics (Dion. Hal. De. Thuc. 29-32). Whatever the event, as Macleod 1979, 52 best puts it, the generalisations put forth in the speeches of even "the most fallible and dishonest Thucydidean orators" invite the reader to apply them widely: "how much more when they come directly from the historian...even if the historian's style is not ideal, it is surely organic, the proper vehicle of his thought". Thucydides' reflections on Corcyra evidently represent an innovation of stasis in the field of fifth-century political science, if not fifth-century politics. See also Ps. Xen. Ath. Pol. 15-6.

${ }^{85}$ Low 2007, 54.

${ }^{86}$ Low 2007, 54. For modern assessments of this phenomenon, see Price 2001, Low 2007, 54-77, 131, $162-$ 4, 222-33, and Gray 2015, 200-3. Kinship and citizenship nevertheless continued to play important roles.

${ }^{87}$ On “city-state culture": Hansen 2000, 2006a, and Ober 2008, 42.

${ }^{88}$ Wendt 1999, 138.
} 
interest are not variables exclusive to Realism; on the other hand, the causal effects of ideas should not be separated from power and interest - a claim rooted both in rationalist and Neoliberal thought. ${ }^{89}$ Rather, in bridging this gap, Constructivists assert that some ideas are interests in themselves, since explanations based upon assumptions of power and interest often presuppose them. ${ }^{90}$ Greek interests changed habitually across international, interstate, and intrastate contexts. Their conceptions of identity, and therefore of interest, however, could be sticky, and often remained rooted to some extent in a broadly homogenous cultural framework, informed and sustained by shared ideas and a common (though oftentimes selective) historical memory. While this certainly favoured the reproduction of particular kinds of Hellenic identity, it did not impose them outright. Balot remarks that the notion of being both united culturally and separated politically imbued the Hellenes with a paradoxical and curious image of the Self, affording them "serious room to explore both ideal and non-ideal possibilities of interstate behaviour". ${ }^{91}$ The roles of opportunism and bias always coattended those of self-criticism and tradition when colouring the Greeks' conceptions of identity. In any case, it is hard to imagine that this amalgamation, rooted both in lived experience and to Hellenikon, failed to disturb the political sphere.

\subsection{Greek Diplomatic Practice}

\section{Institutions and Personnel}

In focusing on the social aspect of politics, it is worth briefly exploring how the Greeks conducted diplomacy, the primary conduit of interstate action. As it happens, conditions in the diplomatic sphere were ripe for prejudicing moral claims and interrogating ideas about Greek society. One of the reasons for this, seemingly, is cultural: unlike modern interstate relations, which are marked by permanent embassies, a copious professional corps, and a specialist vocabulary, the Greek institution of diplomacy was informal and somewhat amorphous:

The first and quite fundamental point to understand is that diplomacy was not regarded by the ancient Greeks as a distinctive and separate function of government; instead, it was seen simply as an aspect of general political activity. As

\footnotetext{
${ }^{89}$ Wendt 1999, 114.

${ }^{90}$ Wendt 1999, 135-8

${ }^{91}$ Balot 2006, 144.
} 
a result, the city-states had nothing remotely resembling a

ministry of foreign affairs or a diplomatic service. ${ }^{92}$

While heralds (kerykes) and sacred ambassadors (theōroi) often opened negotiations - and were protected even in the most bitter circumstances because of their connection to the divine - they were usually followed by embassies composed of active statesmen. ${ }^{93}$ As the careers of Cimon, Pericles, Brasidas, Agesilaus, Epaminondas, Demosthenes, Aratus, Philopoemen, Polybius, and even the Hellenistic monarchs demonstrate, diplomacy comprised an elemental part of statesmanship. Alongside their roles as leaders, orators, generals, and kings, these men all represented their state in a diplomatic capacity over the course of their public - sometimes even their private - lives. ${ }^{94}$ Some were also proxenoi for other states: in Athens, Cimon, Callias, and Alcibiades were proxenoi for Sparta; Thraso and Demosthenes proxenoi for Thebes; and Nicias proxenos for Syracuse. ${ }^{95}$ Straightaway, one may recall instances where these men were pivotal in shaping, for better or for worse, Athenian relations with the polis for whom they were proxenos. Flower has argued, for instance, that in 462 Cimon sought to create through his ties to Sparta a dyarchy between them and Athens aimed, not at Greece itself, as most scholars have taken Plutarch's Cimon 16.8-10 to imply, but at Persia, looking to continue the campaign which had culminated in the Delian League's stunning victory at Eurymedon river just a few years earlier. Nicias' proxenia caused many Syracusans to pity his fate in Athens' disastrous Sicilian expedition in 413 (Diod. 13.27.5-6); and, finally, Demosthenes' role as proxenos for Thebes was crucial in shaping their decision to join the anti-Macedonian coalition at Chaeronea in $338 .{ }^{96}$ Philip II, who could reportedly discover "within hours what his arch-opponent Demosthenes had said in his speeches in Athens", took neither his oratory nor his political action lightly (Diod. 16.87; Plut. Dem. 18.3). The direct involvement of leading statesmen and, later, of Hellenistic kings and Roman consuls did little to mitigate the influence of

\footnotetext{
92 Berridge 2018, 5, who gives a firm introduction to Greek diplomacy. See also, for the Hellenistic period, Grainger 2017. On the negative effects of Greek diplomacy's 'limited' function: Eckstein 2008, 12.

${ }^{93}$ On the influence of kerykes: Berridge 2018, 11-3; on theōroi, see below, ch. 2. Heralds were the only means of communication between warring states upon the outbreak of the Peloponnesian War: Thuc. 2.1.1.

${ }^{94}$ Diplomatic activities of Cimon: Kagan 1990, 31-2; Pericles: Plut. Per. 17; Brasidas: Thuc. 4.85. Agesilaus: Xen. Hell. 5.3.14; Epaminondas: Xen. Hell. 5.1.31-2; Demosthenes: Dem. 9.15, 18.25-30; Aratus: Plut. Vit. Arat. 50.7-10; Philopoemen: Plut. Vit. Phil. 12, 15; Polybius: Polyb. 24.6.5, Walbank 1957, 1-6. We will see several examples of Hellenistic monarchs subsequently.

95 Berridge 2018, 9. Jason of Pherae was also the proxenos of Sparta in Thessaly.

${ }^{96}$ Flower and Cimon: 2000b, esp. 77-83; Demosthenes: Berridge 2018, 44n.110.
} 
personal passion in diplomacy, and troublingly conjoined the spheres of raw political action and sensitive arbitration.

Nevertheless, arbitration between the Greeks was common, dating back to the Archaic period and ostensibly even to the Heroic Age. ${ }^{97}$ And it is said by Gruen to be "a basic fact" that interstate arbitration was as deeply rooted in the Greek past. ${ }^{98}$ Initially, states were reluctant about binding themselves to other poleis or alliances, since this entailed a reduction of their political autonomy. ${ }^{99}$ But this did not in itself deter interaction; the dense concentration of autonomous Greek states in so small an area necessitated constant overtures between them. But other poleis would be invited to judge disputes (predominantly concerning land ownership, the control of sanctuaries, and the delineation of borders) as third-party arbitrators, or ekklētoi. ${ }^{100}$ By the advent of the fourth century, states became increasingly interdependent through obligations to alliances, multilateral treaties, and federal legislation, and so diplomacy only became a more common practice in the Hellenistic period. ${ }^{101}$ Poleis retained their freedom of action, counterintuitively, by signing increasing numbers of agreements and by invoking more poleis to become arbitrators, a role which itself garnered increasing prestige. ${ }^{102}$ This way, statesmen could refer justifications for any policy back to at least one of several diplomatic outlets.

\section{Communication and Tone}

In terms of language, the Greeks' diplomacy was belligerent and idealistic. Oratory and persuasion were considered crucial elements of statesmanship. And, cutting across conventional period divisions, the similarities of both theme and style in, for example, the speeches of Hermocrates of Syracuse in 424 and Agelaus of Naupactus in 217 is striking. ${ }^{103}$ While they rightly evoke historiographical questions, it cannot be denied that the accounts of such speeches offer an authentic sketch of what Greek diplomacy sounded like. ${ }^{104}$ Grant

\footnotetext{
97 An inciting incident of the Iliad is Agamemnon's unfair arbitration with Achilles. There are also other scenes of arbitration: Hom. Il. 18.497-508.

${ }^{98}$ Gruen 1984, 96.

${ }^{99}$ So Ehrenberg 1960, 112-3. For general discussion on the rise of interstate contacts and federalism, see Walbank 1981 and Mackil 2013, esp. 21-147.

${ }^{100}$ Ehrenberg 1960, 102, Gruen 1984, 97.

101 Adcock 1948, 3-8; Grainger 2017, 2-4.

102 Adcock 1948, 5-7, Gruen 1984, 97. Berridge, 2018, 42-5 believes that, while these arrangements tended not to last for their full duration, Greek treaties were nevertheless "fit for purpose".

${ }^{103}$ Polyb. 5.103 and Thuc. 4.59-64. De Sanctis 1934, 108-9 analyses the two speeches (see Walbank 1957, 629).

${ }^{104}$ Generally good on the speechwriting methods of the historians is Luce 1997. If we follow Polybius (2.5663 ), we may reserve doubts about the forerunners of the 'tragic' style, Duris, Timaeus, and Phylarchus.
} 
has suggested its cavalier tone correlated with Greece's agonistic political conditions, themselves informed by a set of competitive social values:

In Greece the neglect of 'co-operative' values or excellences, the persistence of the Homeric $\dot{\alpha} \gamma \alpha \theta$ ó $(\dot{\alpha} \rho \varepsilon \tau \eta \eta)$ standard, with success

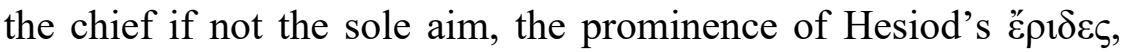

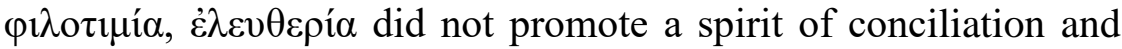
compromise, or devotion to a common interest: stasis at home and war abroad were the normal conditions. ${ }^{105}$

Rivalry, phthonos, and philotimia bled into the diplomatic sphere, but Greeks were not afraid to talk about these things openly. Ober rightly states that "the question was not simply 'how best to destroy our rivals and survive their attempts to destroy us? - but also "which rivals ought we cooperate with, to what extent, and in what domains?". ${ }^{106}$ The second-rate status of most Greek states in the Hellenistic period made such a question by then especially pertinent. And yet, all the same, spanning the fifth down to the second centuries, speeches remained laden with tactlessness, reversals of blame, threats, and recurrences to idiomatic moral claims (Thuc. 1.40.3, 4.87, 6.76-80, Xen. Hell. 3.5.8, 10, 14, 6.3.7, Hell. Oxy. 12.4-5, Polyb. 18.1, Livy 35.33-4). Again Grant linked this diplomatic hostility back to a social belligerence, for which we see evidence elsewhere in the agōn of Classical drama (Eur. Andr. 577 ff; HF 140; Alc. 629). ${ }^{107}$ It illustrated "national character", he thought, "and we should not expect diplomatic practice to have been unaffected by these national characteristics". ${ }^{108}$ Here it is important to draw a distinction between "nationality", as a socially constructed identity, and race, since these two things have often been conflated (especially in the past) in approaches rooted in positivistic or behaviouralist conceptions of the "political culture". ${ }^{109}$ For Greeks, certain incompatible cultural aspects - eleutheria and philotimia, for instance, or philoneikia and homonoia - saw the realm of diplomacy become not just combative, but also one which facilitated reflection on the nature of to Hellenikon, and on the proper adherence to its norms.

\footnotetext{
105 Grant 1965, 261-2.

106 Ober 2008, 83.

${ }^{107}$ Ancient diplomacy has been described as resembling bitter personal quarrels: so Grant 1965, 262; Eckstein 2006, 58, and 2008, 13.

108 Grant 1965, 262.

${ }^{109}$ See Lawson 2006, 125-46.
} 
Finally, most conferences were open and public affairs, playing out before state assemblies and other bodies able to act and create policy in response to what they saw. The ambassadors of Mytilene in 428/7, for example, were forced to watch on anxiously as the Athenian assembly dilly-dallied over the fate of their fellow citizens - the passions of the predominant speakers provoking rapid and contradictory outcomes (Thuc. 3.36, 49). The same assembly was swayed by the rhetoric of a Spartan envoy urgently seeking aid against Thebes in 370 (Xen. Hell. 6.5.33-4). ${ }^{110}$ Even in Macedon, a peripheral kingdom with no popular assembly, a delegation of Greek ambassadors spoke before embassies from other major poleis in the prelude to signing the Peace of Philocrates. ${ }^{111}$ Aeschines, amongst those present at the talks and yet another example of an orator who engaged in diplomacy on behalf of the state, recalled telling his fellow ambassadors: "all Greece is watching to see what happens" (2.104). Evidently, the success of Greek diplomacy rested, at least in part, on its sensitivity to the disposition of the public sphere and to that of other powers in the Greek world.

\section{Hellenistic Innovations}

While the Hellenistic world showed itself to be broader and, in some ways, more volatile, arrangements with the Hellenistic kings helped to ensure a greater degree of security for Greek poleis - at the cost of some independence. ${ }^{112}$ Interestingly enough, an ameliorative quality of this new relationship was that monarchs often took care to situate themselves and their conduct appropriately within the confines of Greek law, or else in conformity to the established norms of arbitration. ${ }^{113}$ They acted largely in mediating capacities when directly intervening in city politics, as epigraphical evidence demonstrates, and often sought to align their verdicts with the civic laws of the polis in question. ${ }^{114}$ Inasmuch as they each sought legitimacy in European Greece, the monarchs were open to a number of political pressures from the Greek poleis, and so the tradition of interstate arbitration remained strong.

\footnotetext{
${ }^{110}$ See Sealey 1993, 71.

${ }^{111}$ Amongst them, Thebes and Sparta: see Berridge 2018, 21.

112 Consider the monarchs' close association of sōtēia and Greek freedom including, amongst other examples, Antigonus' Monophthalmus' deliverance of Athens from Cassander, and the epithets of Ptolemy I and IX and Antiochus I and Demetrius I of the Seleucid Empire.

${ }^{113}$ Walbank 1981, 141.

${ }^{114}$ Strootman 2011, 144-5, Walbank 1981, 141. For an epigraphical survey, see O’Neil 2000. In Livy 31.25, Philip abandons his grand strategy to secure co-operation from the Achaean League in the Second Macedonian War because of a technicality about the agendas of league meetings, to which he adheres.
} 
In federal states, multilateral disputes amongst members were internally resolved by representatives of the league. Treaties between poleis continued to be signed with third parties prescribed to judge in the event of further difficulties. And yet, despite the many political innovations of the Hellenistic period, Greek diplomacy generally reveals much the same trends as before: charged moralising language; no career diplomats or permanent missions (despite an increase in bureaucracy); and an alarming proximity to sovereign bodies of political power, which allowed for the enaction of ad hoc and oftentimes premature policy or legislation. ${ }^{115}$ The Hellenistic world expanded the periphery of Greek diplomacy but nuanced its characteristics only a little: it remained, for the most part, performative and bellicose. The informal nature of Greek diplomacy is thus considered by some to have been an impediment to its practical efficiency, failing in the end to resolve problems and mitigate conflict. ${ }^{116}$ But whether we opt to reject this conclusion (as with Low and Berridge) or not, the fact remains: it is precisely diplomacy's combative and structurally loose environment which afforded aspects like precedence and normativity the space to prevail.

\subsection{The Development of Panhellenism}

Having sketched what Greek diplomacy looked like in practical terms, two distinct kinds of Panhellenism will now be outlined and discussed in terms of their relevance to the proceeding chapters. This section uses Berlin's Two Concepts of Liberty to distinguish between positive and negative kinds of Panhellenism: positive in the sense of presence, as in possessing the freedom and self-determination to do something (like invade another state); and negative in the sense of absence, as in being free from certain restraints (such as external rule). ${ }^{117}$ So far, we have considered three interrelated themes predominant in Greek interstate relations: the rights, positive and negative, of the polis; 'the freedom of the Greeks' as a loose political concept; and the antithesis between Greeks and barbarians. We have explored them in order to understand how they came about and helped to cultivate a self-conscious Hellenic identity. We have now also seen that the characteristics of Greek diplomacy helped to foreground and magnify perceived elements of the Hellenic "national character". Insofar as the Greeks both resonated with and fine-tuned these ideas, they were

\footnotetext{
115 Contra Low 2007, 77-128.

116 This is the sentiment of Adcock 1948, Grant 1965, and esp. Eckstein 2006, who asserts such tendencies expose the "dangerous diplomatic myopia of the powers, typical of the Classical age". Cf. Low 2007 and esp. Berridge 2018.

${ }^{117}$ Berlin 1969, 118-72. Similar work has been undertaken with respect to Panhellenism by Low 2018, who features regularly throughout the present section.
} 
sustained, refracted, and reproduced, to become flexible aspects of one's identity with which the mercurial demands of interstate politics could be better accommodated and endured.

\section{Positive Panhellenism}

At the end of the fifth century, the Peloponnesian War had dangerously enervated most poleis and had left some entirely destroyed. And at its final stage, the conflict signalled the return of the Persian Empire into Greek politics in a serious way. Both the Athenians and the Spartans had compromised the Greeks' collective take on Persia by collaborating with them in exhausted efforts to undermine each other. ${ }^{118}$ Intra-Greek conflict spilled further into the Corinthian War, which raged on in turn until 387. But we have seen a simultaneous desire that existed amongst Greeks to mediate and resolve interstate conflict. The ideology of the Common Peace resulted from this atmosphere, and some sought to take it even further. The fourth-century attempts at fence-mending, coupled with the Greeks' general weariness with interstate conflict, coincided with what is now considered to have been a golden age of Panhellenism.

Around the beginning of the century, Gorgias and Lysias each delivered an Olympic oration on the theme of a Panhellenic war against Persia. ${ }^{119}$ And the successful extraction of the Ten Thousand in 401 from deep within Persian territory left a significant impression on later Greek imaginations, especially after Xenophon, himself an elected leader during the march, committed the events to writing in his Anabasis. ${ }^{120}$ Jason of Pherae, for one, is reported to have thought that the ultimate success of the Ten Thousand demonstrated fundamental weaknesses in the Persian Empire (Xen. Hell. 6.1.12). ${ }^{121}$ For Philip II, it is said to have likewise been a key motivator for his Persian campaign (Polyb. 3.6.10-2). And, if we follow Polybius, this campaign was further motivated by Agesilaus' subsequent invasion of Asia Minor only a few years later (Polyb 3.6.10-2, cf. Arr. Anab. 1.12.3-4, 2.7.8-9). The latter campaign was advocated for by Lysander, yet another whom Xenophon deemed to have been motivated to policy by the events of 401-399 (Xen. Hell.

\footnotetext{
${ }^{118}$ Instances of Athenian and Spartan collaboration with Persian elements: Thuc. 4.50; 8.5.4-6.3; 18; 28.2-4; Andoc. 3.29. Even here, the picture is complicated. Athens supported rebel satraps, whereas Sparta received aid directly from the king, which the Athenians had been refused.

${ }^{119}$ On these: Flower 2000b.

${ }^{120}$ On the Anabasis as an influential Panhellenic text: Jaskelevičius 2018.

${ }^{121}$ Flower 2000b, 96n.20.
} 
3.4.2; Ages. 1.8). ${ }^{122}$ Whatever other Greeks thought of his designs, Agesilaus was profoundly committed to wrapping the campaign up in Panhellenic packaging, and the notion that Persia was weaker than expected appears to have been gaining traction.

The underlying influence of Xenophon across these examples is strong. But while he appears to reflect (and himself to cultivate) a growing awareness in Greece of the perceived vulnerabilities of the Persian Empire, he nowhere espoused a direct Panhellenic programme. Rather, Panhellenism found its most assertive advocate in Isocrates. Himself mindful of the effects of the Anabasis and of Agesilaus' campaign (Paneg. 146-50; Philip 86-8), the kind of Panhellenism which Isocrates espoused was positive, aggressive, and idealistic, seeking a united war against Persia which would bring about both vengeance and freedom for the Greeks. ${ }^{123}$ He saw Greek unity as being inseparable from success against the Persians, the two elements becoming circular and mutually reinforcing:

One must do nothing until they find the Greeks engaged in one of two things: making the expedition [against Persia]; or else sharing along with those who are making it...Therefore those who plan sensibly must not go to war with the king of Persia until someone has produced reconciliation amongst the Greeks and put a stop to the madness which now afflicts them.

Isoc. Philip $86-8 .^{124}$

The Philip is considered by some to be the culmination of Isocrates' Panhellenic thinking. ${ }^{125}$ And it is generally from the works of Isocrates that our conventional understanding of Panhellenism arises. ${ }^{126}$ As the Philip and other documents suggest, the essential concerns of Isocratean Panhellenism were with the Greeks' like-mindedness (homonoia), political reconciliation, and the subsequent prosecution of a war against Persia and the concomitant liberation of Greece. ${ }^{127}$ Isocrates urged Philip to lead the Greek states as one using not his strength of arms, but rather his phronēsis, dikaiosynē, and

\footnotetext{
${ }^{122}$ Agesilaus also sought to re-enact Agamemnon's sacrifice at Aulis, but was frustrated in the attempt by Thebes.

${ }^{123}$ Flower 2000a, 103-4; 2000b, 94-5.

124 This mutual dependency has been identified and well explored by Low 2018.

${ }^{125}$ Dobesch 1969; Payrau 1971. See also Low 2018, 455.

${ }^{126}$ Indeed, Flower $2000 \mathrm{~b}$ has traced the 'Isocratean' school's origins back through the fifth century to Simonides. On the variable definitions of Panhellenism generally, see the introduction to Mitchell 2007. Other intellectuals looked similarly to Philip II: Markle 1976.

${ }^{127}$ See also Paneg. 3, 15; Antid. 77; Panath. 13-4, 42, 77, 217; and Letters 3 and 9.13.
} 
philotimia (5.110, 135; ep. 3.4). In so doing, he likened him to his mythical ancestor, the Panhellenic hero Heracles, showing how he resolved the Greeks' philoneikia and factionalism stasis, single-handedly surpassed the successes of the Trojan War, and championed Greekness in the face of several barbarian enemies (5.111-2). To enforce the centrality of philotimia, he also claimed that it would be "easy to prove" that these successes owed more to Heracles' love of honour than to his physical strength (5.110). Markle reinforces the practical function of mythical precedent in Greek politics, and uses its pervasiveness across the public sphere as an argument to refute the assertions of rationalists:

Rationalist opinion tends to discount the importance of myths used for political arguments in antiquity, and says that they were not taken seriously by anyone. But such a view does not explain why everyone, not only intellectuals secluded in the schools but active politicians in public debate, employed such techniques. ${ }^{128}$

Isocrates evidently thought that Philip's position and influence could help to bring about the reality of Greek unity; and it is no secret that he had appealed to various autocrats to similar effect in the past. Jason of Pherae, Dionysius I, and Archidamus of Sparta were all recipients of letters from the rhetorician. Moreover, he had similarly praised Evagoras, king of Cypriot Salamis, as a model Greek ruler specifically because he had resisted Persian encroachment, despite the terms of the King's Peace (Evag. 3). Berlin, along with several other liberal thinkers, notes that positive freedom can become dangerously associated with authoritarianism, a tendency which Isocrates' behaviour seems to exemplify. ${ }^{129}$ But until it was somehow brought about that at least four major poleis Athens, Sparta, Argos, and Thebes - were reconciled, Isocrates believed that the rest of the Greek world would remain fractured and in a state of conflict $(5.30-1$, ep. 3.2$) .{ }^{130} \mathrm{~A}$ common campaign against the Persian Empire was the only avenue through which the internecine struggles of the Greek world might be transcended (5.30-5). To recall Perlman, the unifying factor was common enmity, not common unity. ${ }^{131}$ The more closely inwards

\footnotetext{
${ }_{128}$ Markle 1976, 97, who then cites examples from Aeschines, Callias, Callistratus, Epaminondas, and Hyperides.

${ }^{129}$ See Carter 2003, esp. section 2, 'The Paradox of Positive Liberty'.

${ }^{130}$ Dmitriev 2011, 56.

${ }^{131}$ Perlman 1976, 3.
} 
one looked, the more exaggerated the Greeks' differences became, for there became fewer external criteria against which to reassert a Hellenic identity.

Isocrates was neither the first nor the only Greek to conflate freedom with a war against the Persians. It was an immediate political reconstruction of the Persian Wars: Greek freedom as maintained through deriving Persian wealth, we know, was the seminal policy of the Delian League in 478; and, in the following century, Agesilaus' campaign against Tissaphernes continued to promote as its aim the freedom of Greek cities in Asia Minor. ${ }^{132}$ Panhellenism's aggressive element appears to have shared a pseudo-scientific connection to Greek identity, seen almost as something innate in the Hellenic ethnos: "the Greek race is both spirited and intelligent", says Aristotle in his Politics, "and this is why it continues to be free, to be governed in the best way, and to be capable of ruling all others if it attains a single constitution" (1327b29-33). ${ }^{133}$ Principally, the framework draws from a shared Greek mythical past and from the tradition - pervasive and emotional - of collective action and freedom, along with the desire to punish Persian hubris (and, no doubt, to extract some profit in the process: Thuc. 1.86; Isoc. Paneg. 17). But it was not the only Panhellenic model to emerge out of the fourth century.

\section{Negative Panhellenism}

Perhaps more useful for our study is the kind of Panhellenism which sought defensively (and less idealistically) to ward off external threats to Greek independence. Isocrates, as we have seen, envisaged a wholesale kind of Greek freedom, brought about aggressively in a war against the anti-Greek bogeyman, Persia. As the catalogue of Panhellenic definitions which Mitchell has compiled illustrates, however, this variation was but one of many available to Panhellenic thinkers. ${ }^{134}$ It was possible, in other words, for states or individuals to utilise a more flexible (and thereby more enduring) kind of Panhellenism, which Low has defined in a recent article:

The first variant form of Panhellenism is distinguished, above all, by its focus on defence rather than attack: the freedom and wellbeing of Greece still needs to be secured, but from a tangible threat rather than the more nebulous menaces envisaged in the Isocratean

\footnotetext{
${ }^{132}$ Low 2018, 456.

${ }^{133}$ Similarly, in the fifth century (as Flower 2000b, 75n.38 notes), Mardonius implies (Hdt. 9.2) that a united Greece would not only resist all foreign invasions but could conquer all others too.

134 Mitchell 2007, xv-Xxii.
} 
model of Panhellenism. A further important difference which follows from this basic point, and which is crucial in explaining the longevity of this type of Panhellenism, is that there is much more scope for variation in the identity of the threat. It might still be Persia, as it is, for example, for Demosthenes in his speech On the Symmories. But the danger can equally well be represented as coming from some other external source - most obviously and most pervasively in Demosthenes' assembly speeches, Macedon. ${ }^{135}$

Whether or not Demosthenes was a Panhellenist is an argument with a long heritage. Even for Dunkel in 1938, "the question [was] not a new one". ${ }^{136}$ And, indefinitely, objections are raised that Demosthenes' Athenocentrism is demonstrative of a cynical kind of stateinterest or Realism. ${ }^{137}$ Panhellenism was for the Athenians, as we have seen, something of a diplomatic "comfort blanket", which they could use to repel suggestions of their imperial insignificance, or otherwise to maintain their sense of identity in changing circumstances. ${ }^{138}$ But we might note the ultimate outcome of Dunkel's survey, and the central imperative that it placed on the truth-value of Demosthenes' policy: "In short, [he] did use Panhellenic appeal. But he did not, in my opinion, have a true Panhellenic feeling". ${ }^{139}$ Whether he believed it or not, he certainly used it, and it was a Demosthenic policy of Athenocentric Panhellenism which induced the Athenians into fighting the battle of Chaeronea and, after it, the so-called 'Lamian War'—known simply as the "Hellenic War" to contemporaries. ${ }^{140}$

Insofar as neither homonoia nor the Persians were considered essential elements of this Panhellenism, any state or individual, whether Greek or non-Greek, was prone to demonisation in the way of Philip by Demosthenes, so long as it could be demonstrated that they impinged (or threatened to impinge) the negative liberties of the Greeks. ${ }^{141}$ For the employers of such language, there was no subsequent requirement for the Greeks to undertake any kind of collective action: "Panhellenic leadership (or a claim to have

\footnotetext{
${ }^{135}$ Low 2018, 457-8. The following paragraphs follow Low 2018 closely.

136 Dunkel 1938, 291. George Grote, as early as 1888, thought Demosthenes was (Vol. 10, 264).

${ }^{137}$ So Dunkel himself: 1938, 305, Eckstein 2006, 66 and 308n.215

138 Athenocentric Panhellenism as a 'comfort blanket': Low 2018, 470.

${ }^{139}$ Dunkel 1938, 205; contra Green 2004, 115.

${ }^{140}$ On the influence and popularity of Demosthenes and his policies: Hansen 1991, 266-287. On the Lamian War's name: $I G$ II $^{2}$ 448.40; 467.7-8; 505.17; 506.9-10; Syll. ${ }^{3}$ 317.6-19; Ashton 1984; Champion 2004, 41.

${ }^{141}$ Low 2018, 461-2.
} 
exercised such leadership) does not, that is, necessarily entail the existence of Panhellenic followers, a situation which - while formally entirely illogical - seems to have been rhetorically plausible, and which is also crucial to understanding the persistence of this language". ${ }^{142}$ In this way the ideology of Panhellenism could be used in an inconsistent (and not necessarily specious) way, for unilateral or hegemonic effect. It was possible for Greeks to fret over the 'Hellenic interest' while simultaneously prejudicing chauvinistic concerns within their polis, seemingly without any feeling of contradiction. ${ }^{143}$ And we have already seen some instances of this kind of dualism at work.

It is evident that, like the Isocratean version, this more versatile kind of Panhellenic rhetoric also operated in the fifth century. ${ }^{144}$ The Spartans appeared to be deploying a version of it: Brasidas, when campaigning in Thrace, deemed the anti-Spartan position as being tantamount to opposing one's own liberation and, by extension, to opposing the liberation of all Greece (Thuc. 4.85.4). ${ }^{145}$ In so doing, he elevated the notion of Self beyond the level of the individual or the state, to instead represent the wider Greek world as an "organic social whole". ${ }^{146}$ Berlin asserts that such an outlook, once utilised, can then be used "to ignore the actual wishes of men or societies, to bully, oppress, torture in the name, and on behalf, of their 'real' selves, in the secure knowledge that whatever is the true goal of man...must be identical with his freedom". ${ }^{147}$ Low has shown how, in a similar manner, Hermione described Sparta's and Persia's vices together in Euripides' Andromache, now bringing the Spartans to occupy the conceptual space typically reserved for the barbarian $(168-75 ; 445-53) .{ }^{148}$ The Athenians later fit the Boeotians and Euboeans into this inimical role when Hyperides delivered the funeral oration of Leosthenes in 323/2, since they had assisted Macedon during the Lamian War (6.11). "To justify attacks on fellow Greeks," says Harris, "one had first to deprive them of their credentials for Greekness. This was similar to justifying attacks on the constitutional rights of American leftists during the 1950s by first labelling them 'Unamerican".. ${ }^{149}$ Rhetorical strategies of this sort may appear parochial or sinister, but their effects cannot have been wholly

\footnotetext{
${ }^{142}$ Low 2018, 460.

${ }^{143}$ Green 2004, 118.

${ }^{144}$ Dmitriev 2011, 15-66, cf. 351; Low 2018, 458.

${ }^{145}$ We have also seen the Mytileneans turn Sparta's self-styling against Athens in 428/7 (Thuc. 3.10.3, 13.7).

146 So Carter 2003's summation of Berlin 1969, 132-3.

${ }^{147}$ Berlin 1969, 132-3, with Carter 2003: "they would not resist coercion if they were as rational and wise as their coercers".

${ }^{148}$ Low 2018, 458.

${ }^{149}$ Harris, in Green 2004, 117n.74.
} 
superficial, since they must have hit upon a notion of what Greeks believed to be aspects of their civic identity and Panhellenic ideology.

Low urges that it is important to remember that such ideas do not stem from nothing. ${ }^{150}$ The negative paradigm was in natural conversation with the positive one, and likewise drew from a nostalgia for the Persian invasions: Demosthenes' Third Philippic, for example, necessarily invokes the Persian menace, the Greeks' old cooperation, and their love of freedom, in order to mould the associated feelings into anger against Philip, and subsequently into Athenian energy:

...we Greeks, instead of sending embassies back and forth and voicing outrage when we see or hear about Philip's activity, are in such a miserable state, so entrenched in our separate poleis, that to this moment we cannot do anything that interest or necessity demands. We cannot unite or form any association for aid and alliance...the Greeks of old were as eager for freedom as their descendants today are for slavery! There was something then, men of Athens, something which animated all the Greeks but which is lacking now; something which overcame the wealth of Persia and upheld the freedom of Hellas — which never lost a single battle by sea or by land; something which now, by virtue of its decay, has ruined everything and dragged our affairs into a state of chaos.

Dem. $9.28,36 .{ }^{151}$

Athenian Panhellenism in the latter half of the fourth century, it has been noted, was especially solipsistic. ${ }^{152}$ It offers perhaps the clearest model wherein a single state sought by their heritage and actions to determine the unity of the "real" Greeks. The Aetolian League would later use their repulsion of a Celtic invasion of Delphi in 279 to similarly assert their status within the Greek world. Centralising the Amphictyonic League, they instituted the Sótêria, a Panhellenic festival which celebrated the deliverance of Greece

\footnotetext{
${ }^{150}$ Low 2018, 464.

${ }^{151}$ The reason, in Demosthenes' view, is Philip's bribery and the Greeks' corruption. This view persisted into the writings of Cicero (Att. 1.16.2), Horace (Odes 3.16), and Juvenal (12.47), but is interestingly resisted by Polybius (18.14). His fragment On Traitors, and the relevance it bears to Aristaenus and the Achaean decision to abandon Macedon in 198, is striking in the themes it adopts from this account.

${ }^{152}$ Low 2018, 464.
} 
from barbarian invasion. ${ }^{153}$ But notions of Panhellenism which privileged a single state could be easy to cultivate homonoia against. And, insofar as it was possible to consider certain Greeks to themselves be the enemies of Greek freedom, a corollary of this unilateral kind of Panhellenism is that non-Greeks could just as paradoxically claim to champion Greek freedom from without. It is thus unsurprising to find Philip engaged in a similar campaign of Panhellenic self-styling as Demosthenes, and manipulating the same institutions as the Aetolians. Indeed, his close association to the Delphic Amphictyony and his characterisation as Apollo's avenger during the Third Sacred War are well noted (Just. 8.2) ${ }^{154}$ By 339, furthered by several diplomatic successes, Diodorus reports that Philip had gained the friendship of "most of the Greeks" (16.84). ${ }^{155}$ Against the rhetoric of Demosthenes, it is equally possible to argue that, although the Atheno-Theban coalition offered Philip formidable resistance at Chaeronea, it "was hardly a Panhellenic force such as had opposed Xerxes". ${ }^{156}$ The semiotics of this conflict might best be understood as a clash between alternating Panhellenisms, as Philip's subsequent policies further illustrate.

After Chaeronea, Philip's goals (like Alexander's after him) were couched in explicitly Isocratean Panhellenic terms. As with Agesilaus, the invasion of Asia would be waged in order to liberate the Greek cities there. ${ }^{157}$ And the official sanction of the League of Corinth - evidently intended to recall the Hellenic League of 481 which met at the same location - was for a war of revenge against Persia, seeking to punish them for the invasion of 480 (Arr. 2.14, Diod. 16.89, Polyb. 3.6). ${ }^{158}$ These may well have been pretexts, as Polybius contended (and as many scholars agree), but this should not altogether disqualify them as evidence of a powerful (and possibly idealistic) foreign policy. ${ }^{159}$ For one thing, Polybius used Philip and Alexander's campaigns to distinguish between causes, pretexts, and beginnings, believing that every event had its "pretext", or prophasis, as a matter of methodology. ${ }^{160}$ In this particular instance, the prophasis lay not just in conquest for its

\footnotetext{
${ }^{153}$ This evidently had lasting effect: Paus. 10.19.5. The Athenians and others were also present at the defence. On the Delphic Amphictyony's importance to the identity of the koinon, see Austin 2006, 129-30; Mackil 2013, 99-100.

${ }^{154}$ For more, see Buckler 1996 and Mackil 2013, 82-9.

155 See also, for Philip's diplomatic successes and lack of force, Dmitriev 2011, 354.

${ }^{156}$ Buckler 1996, 91 reckons some eight poleis were present on the side of the coalition.

${ }^{157}$ Flower 2000a, 100, esp. n.17. Cf. FGrH 115, F 253.

158 Vlassopoulos 2013, 74-5. A similar, broad-based Hellenic League was forged by Antigonus III Doson to prosecute the Cleomenean War in 224.

${ }^{159}$ Flower 2000a, 100.

160 On Polybius' mechanical sequence of cause and effect: Walbank 1957, 305-6. It may be less charged translate $\pi \rho$ ó $\varphi \sigma i \varsigma$ as 'motive', 'occasion', or 'basis'. The word encapsulates both alleged and actual causes across our sources: see, generally, Pearson 1972. For Polyb. 3.6 in particular: 387.
} 
own sake, but in Philip's "ardent desire to avenge the injuries which the Persians had previously inflicted on Greece", a phrase which appears to contradict the claim that Polybius rejected any notion of Philip's personal attachment to a war of revenge (3.6.13). ${ }^{161}$ Moreover, Diodorus (if he is to be believed) states that delegates at the meeting in Corinth were genuinely won over by Philip's zeal, both to punish the Persians' religious transgressions and to personally champion the war (16.89.2). ${ }^{162}$ The conquest was at least presented as a Panhellenic project centred around a congress of eager Greek states.

And again, even if it could be demonstrated objectively that Philip's pretext was of a cynical nature, the result would be immaterial, so long as the desired results - of winning Greek support by packaging the campaign as Panhellenic - were achieved. As Low reminds us, "an investigation of the norms of interstate relations must take as its starting point the possibility - even the probability - that, in appealing to those norms, everyone could be lying". ${ }^{163}$ As far as our sources indicate, it was indeed through the propagation of Panhellenic ideology that Philip accomplished his aims. ${ }^{164}$ And whatever Polybius thought of his intentions, he ultimately accredited Philip with having obtained "the unanimous goodwill of the Greeks" (3.16.13). ${ }^{165}$ Philip's self-styling as a Greek hegemon and avenger would have also drawn contrasts to Jason of Pherae, whom Xenophon deemed to have acquired an ultimately tyrannical reputation (Hell. 6.4.32, cf. Isoc. To the Children of Jason). Even if they did not credit Philip with being genuine, therefore, Polybius, Diodorus, and others still demonstrate the power of those common values philotimia, avenging the invasion of 480 , freeing Greek cities from tyranny - in pervading the Greek consciousness.

In response, Demosthenes' negative Panhellenic logic stretched to accommodate what was practically a 180-degree turn. In the Fourth Philippic, the orator urged his fellow citizens

\footnotetext{
161 This, amongst many others, is the belief of Flower 2000a, 102. Cf. these remarks with Polybius' later historical criticism of Theopompus in 8.8-11, a passage which puts the author's integrity in central position. While it contains the notorious quip, "It would surely have been more dignified and just to include Philip's achievements in the general history of Greece rather than the other way around", he nevertheless shows a high regard for Philip, Alexander, and the Diadochs (8.10.6-8).

162 On why we might be sceptical: Flower 2000a, 101n.23.

${ }^{163}$ Low 2007, 257. This observation is also made in this context by Flower 2000a, 102. Generally, in reacting to Thucydidean Realism, Hawthorn 2014, 84-101 demonstrates the force of this kind of argument.

${ }^{164}$ Pohlenz 1966, 20; Flower 2000a, 101. See also the remarks of Isocrates in Letters 3.

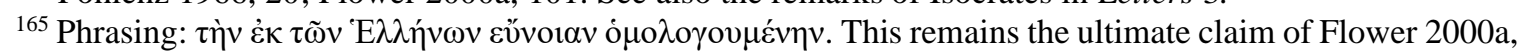
101 , despite his different reading of Polybian opinion about Philip.
} 
even to forget old prejudices against Persia and to reconcile them, so that they might fully recognise the king of Macedon as the true threat to Greek security:

I think you should send an embassy putting all these matters before [Artaxerxes], and you should drop the foolish prejudices that have so often brought your problems about: 'the barbaros'; 'the common foe of us all'; everything like that. I am bewildered any time I see a man frightened of someone who lives in Susa or Ecbatana and insistent that they are ill-disposed towards Athens (even though they helped to revive our fortunes in the past and have even now been making overtures to us)... and then I find that same man using very different language about this marauder of the Greeks, who you can see extending his authority in the Greek heartland and up to our very gates! Whoever that man might be, it is I who fear him, precisely because he does not fear Philip.

Dem. 10.31-4. ${ }^{166}$

Shortly after, Athens went to the aid of Byzantium, then under siege by Macedon, and so too did Artaxerxes. The Athenians then declared war on Philip and sent a delegation to the Great King looking to form an official alliance. ${ }^{167}$ The ambitious and unilateralist Greek identity visible in fourth-century Athenians like Demosthenes and Hyperides situated their polis as the "sun around which all Panhellenic activity revolved". ${ }^{168}$ By reconstituting the identity of the barbarian threat to Greek security, they could simultaneously effect a rapprochement with Persia while sustaining Athens' proud image as a champion of Panhellenic values. It will be suggested that later, in the third century, a similar logic of philotimia and Panhellenic solipsism played an integral part in animating Greek states' appeals to Rome, in addition to their more pragmatic and rationalistic concerns about Philip V.

\footnotetext{
166 On the authenticity of this speech: Worthington 1991. Demosthenes refers to Conon's military victory in 394 against Sparta, achieved with Persian help, and condemns the Athenians for rejecting Artaxerxes' request for aid during the Egyptian rebellion of 345-a request which the Thebans and Argives accepted.

${ }^{167}$ On the complexities of Greek, Persian, and Macedonian relations and treaty arrangements between 346 and 336: Buckler 1994. See also ps.-Dem 11.5-6. On the Fourth Philippic: Green 2004, 127-8. Artaxerxes, despite opposing Philip around the Hellespont in his right, ultimately rejected the Athenian appeal.

${ }^{168}$ Low 2018, 469.
} 


\subsection{Summary}

What remains evident, for our interests, is the way in which Panhellenism and its associated feelings were not limited to the traditional, Isocratean rendering. After Alexander's conquest of the Persian empire, the Greeks in fact lost the mirror against which much of their Classical identity had been constructed. But even before the 330s, Demosthenes had cultivated a perception of Macedon which fit all the descriptions of Persian barbarism. Doubtless, variant forms of Panhellenism coexisted and survived without Persia: in the eyes of fourth century and later Athenians, Thebans, Aetolians, and others, Philip and his successors could be constructed - as much as the 'darlings', or 'saviours' of Greece - as its implacable enemies: monarchs and tyrants - the Other, in other words, "the polar opposite of the Hellenic ideal" (Polyb. 7.12; Plut. Arat. 16.4, cf. 38.2). ${ }^{169}$ Idealising leads to exaggeration, and creates utopian or dystopian imagery. The maintenance of two identities - Hellas and polis: one with an eye to the outside and another to the inside - facilitated a range of complex and sometimes formally illogical social and political behaviours.

It is certainly correct to say that Panhellenism's categories were far from being sharply defined, and that Persia - although formative in creating a Greek political selfconsciousness - in no way monopolised the role of barbaros, not least in the fourth century and after. ${ }^{170}$ To reconfigure Wendt's phrase about the social construction of anarchy in international relations, Panhellenism "is what states make of it": Persians; Carthaginians; Thracians; Macedonians; even the Greeks themselves could be configured within the elastic role of the anti-Greek. ${ }^{171}$ Determination of the target was contingent on the experiences, self-styling, and prejudices of not only those who appealed to the cache of cultural and political currency stored in the bank of Panhellenic language, but also of those who felt it. It can never have been wholly cynical. As with the Classical examples, the Lamian and Chremonidean wars, Pyrrhus' invasion of the Peloponnese, and Aratus' repatriation of the Acrocorinth were all animated, to a greater or lesser extent, by this same intricate tension between notions - sometimes common and sometimes contradictory - of Greek identity, state interest, and 'national' purpose. ${ }^{172}$ It would be difficult to expect Greek behaviour at the time of the Social War - where one side was composed of a

\footnotetext{
${ }^{169}$ Green 2004, 128.

${ }^{170}$ Green 2004, 118

${ }^{171}$ So Wendt 1992.

172 Aratus: Tatum 2019, 73.
} 
Hellenic League and another spoke of uniting "to repulse the invasions of barbarians" to have been otherwise (Polyb 5.104). When Agelaus cast his eye towards the barbarian "clouds in the west" in 217, however, a new power other than Macedon would be invoked to fit - or break - the mould. 


\section{Chapter Two}

\section{Interstate Politics (217-205)}

\subsection{Introduction}

In this chapter I apply a Social Constructivist framework to some key interstate moments in Greece between 217 and 205, the period from the end of the Social War to the end of the First Macedonian War. This and subsequent periods of Greek history have been predominantly treated through the lens of Realism. Moreover, there is a tendency to focus on systemic or metrocentric explanations of Roman imperialism, as well as the impact of "given" material dynamics in Greece (such as the balance of power), which are defined chiefly in military and economic terms. The Greek states of this period offer plentiful evidence, however, for acting also on the basis of ideas, and for rooting their interests in concentric circles of identity, sometimes beyond the level of the state. Foremost amongst these is the attribution of great significance to the identity of "the Hellenes" as a selfconscious and political 'We'. Champion speaks of "monumental convulsions in Greek historical experience", of which the first two were the Persian Wars of the fifth century and the rise of Macedon in the fourth. ${ }^{173}$ It will be argued that the years 217-205 constituted the origins of something like a third monumental convulsion, tracing back to and engaging with the two prior crises. In response to the (especially non-Greek) violence which erupted across Greece during the Aetolian War of 211 - in effect a revival of the Social War, spurred on through Roman contrivance - several Greek states and Hellenistic monarchs explicitly reaffirmed their commitments to the principles and values of Hellenism. States stressed their fidelity to this broader Hellenic identity because the cultural conceptions rooted in it were felt to have obtained a greater significance within this (as in other) contexts of perceived convulsion and crisis.

As in the past, the Greek states' material interests were coloured by, and oftentimes commensurate with, Greek ideas. By criticising those deemed to be acting in betrayal of such ideas, the Greek powers evince a socially constructed system of acceptable interstate behaviour, in which friendship and enmity are determined as much by might and security as by conceptions of Greek identity, memory, and non-Greek barbarism. Insofar as such conceptions were discriminating and liable in terms of context, these social constructions

173 "monumental convulsions" in Greek memory: Champion 2004, 39-40. This idea is related to Wendt's $(1999,312)$ evolving cultures of anarchy, which "may not survive exogenous shocks, like invasion”. 
cultivated conceptions of state and Hellenic interest which, with respect to Greece at large, were convergent in some instances and divergent in others. Panhellenism was a powerful force because it intersected the Greeks states' incongruent civic and cultural identities. Opposing states could simultaneously claim to champion Panhellenism through the "multiplicity of its voices", shaping other states' perceptions of the Hellenic interest. ${ }^{174}$ While the proper pursuit of that interest was frequently the object of debate, Hellenic principles remained at the fore of consideration: all interstate claims were couched in calls for Greek unity, Greek freedom, and the defence of the right to claim Greek affairs for themselves.

By this time, primordialist claims to Hellenism remained but were coattended by constructivist ones. This had a profound impact on the conduct of interstate relations, since peripheral and non-Greek states championed competitive notions of Hellenic interest with growing legitimacy. Within Greece, the pervasive legacies of the common dangers posed by Persia and Macedon enabled the invocation and deployment of a range of selective and divergent conceptions of Hellenic interest and institutional memory. Macedon's position had always been ambiguous, and while some states sought to employ a Greek politics of cultural assimilation of Macedon, comparing states like Rome to Persia - the archetypal barbarian menace (a politics which the Macedonians themselves played an active role in) - other states resisted, using Roman support to instead propagate a Greek politics of cultural alienation against Macedon. As is implied by the imperative which Social Constructivism places on culture, this chapter follows Gruen, Champion, and Dmitriev in seeking to offer a metrocentric account of Greek (as opposed to Macedonian or Roman) behaviour at this time, in order to better understand the forces which animated their conceptions of interest and, subsequently, their decisions of policy. This approach aims to avoid the common slip of building these cultural elements into explanations of interstate relations, while denying them of their impact - a phenomenon Wendt describes as cheating the materialismidealism test. ${ }^{175}$ Allotting the appropriate significance to the contexts of meaning built around the material interests in Greece is key, in other words, to understanding what animated Greek and other actors at this time. Naturally, inasmuch as they are the chief sources for the period, historiographical discussions of Livy and especially Polybius remain pertinent in the proceeding section.

\footnotetext{
${ }^{174}$ Mitchell 2007, 206.

175 "Cheating" the materialism-idealism test: Wendt 1999, 136.
} 


\subsection{Sources Ancient and Modern}

The $139^{\text {th }}$ Olympiad (224-220) saw major political changes occur across the Mediterranean: Hannibal assumed command of Carthaginian forces in Spain in 221, and all three Hellenistic kingdoms witnessed the accession of a new monarch (Antiochus III in Syria in 223; Ptolemy IV in Egypt in 221; and Philip V in Macedon later that year). ${ }^{176}$ During the $140^{\text {th }}$ Olympiad (220-216), the point at which Polybius began the main narrative of his Histories, Hannibal inflicted three catastrophic defeats on the Romans, killing over 100,000 fighting men. ${ }^{177}$ In response to the Battle of Lake Trasimene, the Romans appointed Fabius Maximus dictator in 217. Philip V of Macedon, ostensibly uninterested in affairs west of the Adriatic, plotted to compound Rome's weaknesses by throwing in his lot with the Carthaginians, sparking the First Macedonian War. Since 220, Philip had headed the Hellenic Symmachy, a large coalition of leagues engaged in a war against the Aetolians in Greece, but he quickly arranged a peace so that he could prepare for new campaigns in Illyria. Within thirty years, however, it would be the Romans who emerged as the undisputed hegemon of the Mediterranean, having bested Carthage, Macedon, and the Seleucid Empire in a series of decisive campaigns.

Naturally, scholars have scrambled to explain how the structure of interstate society facilitated such widespread upheaval. And many, owing to the magnitude of conflict and system change during this period, have opted to write with a Realist bent, whether veering towards its more classical or Neorealist assumptions. ${ }^{178}$ Polybius (c.200-118), our essential Greek source who lived through the subsequent turbulence of the second century, seems himself to have informed the trend. In many ways, he wrote in the Thucydidean tradition: both of their histories are political and military in nature, pragmatike and scientific, and intended as useful works for future generations (Polyb. 1.14.6, 35, 9.2; Thuc 1.22). Moreover, each history is largely contemporary, anticipated by a summary of events in the preceding half-century. And Polybius, like Thucydides, held high public office amidst the years he recounts, prejudicing practical and military experience, geographical knowledge, and eyewitness accounts over the conventions more typical of armchair history (though this is not to say that he did not actively seek out and rely on official documents, transcripts,

\footnotetext{
176 Walbank 1984, 473.

${ }^{177}$ If the numbers of Polyb. 3.72-4, 84-6, and 117 are to be believed, somewhere between 115,000-150,000 Roman men were killed by Hannibal between 218 and 216 at Trebia river, lake Trasimene, and Cannae. ${ }^{178}$ So, amongst others, Harris 2004, 17-30; Rich 2004; Waterfield 2014, Neorealist: most explicitly Eckstein $2006 ; 2008$.
} 
and other records). ${ }^{179}$ Whatever the event, Polybius appears to have written with an agnostic, rationalist and, one hesitates to say, Realist worldview. ${ }^{180}$

Perhaps the greatest difference between Thucydides and Polybius is one of scope. Whereas Thucydides devoted stringent focus to the events of the Peloponnesian War, Polybius attempted to compose a universal history, which in a clockwise cycle covered several Mediterranean arenas (Polyb. 1.4.2, 2.37.4). ${ }^{181}$ Thucydides' motive for writing a history of the Peloponnesian War lay in its generation of kinēsis-disturbance or upheaval (Thuc. 1.1). ${ }^{182}$ Surpassing even its Trojan and Persian predecessors, he asserted that the Peloponnesian War represented the greatest kinēsis in Greek history, a coming together between Athens, Sparta, and their respective coalitions. And we have seen how his methodology conceived of it, generally, as a kind of Hellenic stasis or civil war. Polybius also wrote with kinessis in mind (3.4.12-3), but assessed the Greek world within the broader context of symploke- the geopolitical convergence of the eastern and western Mediterranean. In this respect his history, although aimed predominantly at a Greek audience, treats with events that are largely exogenous to the Greek world:

Is there really anyone so negligent or apathetic that they would not want to know both how and by what polity almost the entire inhabited world came to be dominated and brought beneath the rule of a single empire in less than fifty-three years?

Polyb. 1.1.5.

The leading question of the Histories, in other words, is one of Roman imperialism. Champion therefore calls Polybius' approach metrocentric, which is to say that it focuses on the social, political, economic, and cultural properties of the imperial power. ${ }^{183}$ Since the Greek states are assessed within a context of their enfolding circumscription by Rome, the project lends itself more readily to explanations of Greek history from a Roman vantage point. Moreover, Polybius' question is teleological: events in the Histories are described in a purposive sequence which anticipates a terminus in 167 (ambivalently continued later

\footnotetext{
${ }^{179}$ Polybian methodology: Walbank 1957, 6-16.

180 Though in their respective histories, claims of reason are often undermined by chance or fate. Thucydides and chance: Luce 1997, 80; Polybius and Tychē: Walbank 1957, 16-26. Polybius as Realist: Gruen 1984, 346-7; Green 1990, 271. Cf. the psychological and dialectical qualities of Polybius' "gaze": Davidson 1991, esp. $21 \mathrm{n} .49$.

181 On Polybian chronology: Walbank 1957, 35-7. See also Luce 1997, 69.

182 Thucydides and kinēsis: Luce 1997, 70-1, 87-98.

${ }^{183}$ Champion 2007, 264. Book 6 of his history is an oft-cited example of metrocentric writing.
} 
down to 146), where the growth of Roman power was felt to have been both total and complete. It is not new to observe that, as a result, scholarship on the period of interest to Polybius has become similarly one-sided. ${ }^{184}$ Robin Waterfield's study, for instance, begins "with the same challenge to the reader that Polybius issued over two thousand years ago"; and there are more works focused chiefly on the growth of Roman imperialism at this time than there are on Greek politics and Greek history. ${ }^{185}$

Closer surveys of Greek interstate politics typically stem from those who take a longer, developmental view towards Greek relations and the growth of its traditions, or from those who study the histories and institutions of its federal states. ${ }^{186}$ Here too, the Roman question remains pervasive. In many ways it can hardly be avoided. After all, the Greek peninsula was the geopolitical springboard for Rome's eastern imperialism; the Greek states were themselves complicit, passively and actively, in entrenching the Roman presence there; and Hellas found herself utterly subject to Roman authority by 146 . So even the accounts of Erich Gruen and Sviatoslav Dmitriev, who seek most exhaustively to keep Hellenic sociocultural and diplomatic norms at the fore, arrive at their own separate explanations of Roman imperialism. ${ }^{187}$ While this cannot, and indeed ought not, be altogether avoided, it does appear to have entailed some unfortunate corollaries: beyond a general shortage of focused, programmatic studies of the nature of Greek interstate relations during this period, there is often a subtle discolouration of the ways in which the Greek states styled themselves and were socialised, influenced by deep-seated continuities and cultural norms when conceiving of their interests.

Our other main source, Livy, also presents difficulties. Writing firstly during the triumviral period and then throughout Rome's civil war between Antony and Octavian - another coalescence of the Greek east and Roman west - Livy's ab urbe condita is first and foremost an austere glorification of Roman history and Roman values. But while ostensibly keeping with the new princeps' movement to revive traditional Romanitas, Livy nevertheless earmarks the older Hellenistic east as a case for close examination. ${ }^{188}$ So Rome's wars against the monarchs in Macedon and Syria comprise fifteen books, of which

\footnotetext{
${ }^{184}$ Gruen 1984, 3; Champion 2007, 264. Some metrocentric examples: Mommsen 1903; Frank 1914; to some extent Holleaux 1935; Badian 1958; Harris 1979; DeSanctis 1969; Rich 1976; Brunt 1978; Raaflaub 1996; Eckstein 2008; Waterfield 2014.

185 Waterfield 2014, xiii.

186 So, chiefly, Larsen 1968 and Mackil 2013.

187 Gruen 1984; Dmitriev 2011.

188 Augustan literature: Pelling 1996, 73-6; Farrell 2005, 44-57.
} 
several draw fully and conspicuously on Polybian material. ${ }^{189}$ In these years, the work regularly echoes that of the Achaean statesman; and where variances occur, it is principally to more forcefully emphasise the providence of Roman supremacy over the orbis terrarum. Once the brothers Scipio defeated Antiochus III at Magnesia in 189, for example, Polybius remarked that "the king's envoys urged the Romans to use their victory magnanimously, since Fortune had granted them world power" (21.16). Livy opted to take the passage further: "You Romans", he has the envoys say, "have always shown magnanimity towards those you have conquered. How much more generously ought you to act now, as masters of the world! Cease from strife with mortals and, like gods, tend and spare the human race" (37.45). ${ }^{190}$ The resemblance to symbolism associated with the Pax Romana is palpable. ${ }^{191}$ Finally, while looser, Livy is himself complicit in the Realist tradition: amongst others, his history inspired Machiavelli to write his Discourses on Livy, a cynical treatise on republics, fashioned as a commentary on Livy's first ten books. ${ }^{192}$

Eckstein believed it to be "no accident that Realist paradigms of interstate behaviour have their origins with thinkers (starting with Thucydides) whose life experience was formed by constant war and instability". ${ }^{193}$ But certainly, though such conditions cultivated a bias towards Realist thinking, it does not follow that Realist paradigms offer a full account of causation, nor of the interplay between structure and agency. ${ }^{194}$ Nor does it follow that a prevalence of such conditions calls only for Realist assessments of periods marked by violent change. In fact, with respect to Thucydides, there are several scholars who are now trying to deconstruct the perceived uniformity of his political thought, and to interrogate the contingent receptions of his History. ${ }^{195}$ And Polybius' work is perhaps even less restricted by any singular attitude towards interstate behaviour. It is worth remembering that an important motive for Polybius, like Thucydides, to write his history at all, let alone in the way he did, rested with his exile, during which time he spent sixteen years in Rome. His status was uneasy, and despite an intimate friendship with Scipio Aemilianus, Polybius

\footnotetext{
${ }^{189}$ McDonald, in Bettenson 1976, 14. Indeed, Polybius is cited by name on several occasions: at 33.11; 34.50; 36.20; and 45.44. on Livy's deployment of Polybius: Levine 2010.

190 This comparative example and its attendant translations are lifted from McDonald, in Bettenson 1976, 8.

${ }^{191}$ See, for example, Hor. Carm. Saec.; Virg. Aen. 6.847-53; and Augustus' Res Gestae.

192 On the influence of Discourses on Livy in the Realist tradition: Gallagher 1993.

${ }^{193}$ Eckstein 2008, 10. Polybian Realism: Green 1990, 281-2, 346-7.

194 Wendt 1999, 242.

195 So, generally, Stahl 2003; Low 2008, esp. 222-33; Hawthorn 2014; with respect to identity: Fragoulaki 2013; deconstructing Thucydides' reputation as 'Father of Realism': Korab-Karpowicz 2006.
} 
must have resented Rome's termination of both his political career and native polity. ${ }^{196}$ Gruen is right to highlight that, "as a Greek who both suffered and benefited from Roman movement into Hellenic lands, he could hardly develop a sense of detachment from the subject". ${ }^{197}$ The Achaean League was, after all, dissolved in the same year that Polybius watched Scipio complete the destruction of Carthage.

But exile afforded the historian some degree of introspective clarity. For Edward Said, the exiled figure's surroundings afford them self-awareness as much as self-assertion: "he or she must cultivate a scrupulous (not indulgent or sulky) subjectivity". ${ }^{198}$ And Plutarch, for one, made a point of the phenomenon that most Greek historians had written from exile, and that this status often detached them from events and broadened their perspectives (Mor. 605c). Like Herodotus, Ctesias, Xenophon, and Alexander's historians before him, Polybius' contact especially with non-Greeks offered him instrumental stimulus not just for writing history, but for sharpening Hellenism over against the cultures and politics of the wider world. ${ }^{199}$ This is not to say in consequence that the universalisms of actors throughout his work are inventions of the author; we know them to be a persistent quality of the oratory and thought which underscored Greek relations and political science. As with all others, Polybius' history evokes the inescapable dialogue between the Greek and the Other, sustaining its centrality as a mode for the construction of cultural, personal, and political identities. While his judgements oftentimes rightly invite our scepticism, we ought not to deprive Polybius altogether of his utility in capturing the conceptual sensibilities of both his environment and that of his immediate predecessors. Despite seeking chiefly to explain Roman power, Polybius' work remains complex, and captures much to do with Hellenism as a combined political and cultural force, and so to do with its cultivation, modification, and deployment at the interstate level.

\subsection{The Peace of Naupactus (217) \\ The Speech of Agelaus}

This brings us to the year 217 and to the Peace of Naupactus, believed by Polybius to have signalled the beginning of world symploke. This peace conference, which ended the Social

\footnotetext{
196 On Polybius and Scipio’s relationship: Walbank 1957, 3-4; Green 1990, 281-2. The clear disparity in tone between his coverage of 220-167 (written while in Rome) and 167-146 (written in Greece) must be coloured as much by his change of surroundings as by his involvement in events.

197 Gruen 1984, 2.

${ }^{198}$ Said 2000, 182. Ancient thinking about exile: Gaertner 2007.

${ }^{199}$ Luce 1997, 142.
} 
War, was capped by a speech from an Aetolian statesman named Agelaus (5.104.1-11). ${ }^{200}$ A supposed representative of the peace party, Agelaus warned of grave tidings looming in the west which might end up, like a cloud, settling over Greece. ${ }^{201}$ The victor of the Hannibalic War, he thought, unsatisfied with supremacy over the Italian peninsula, would soon turn their eye beyond the Adriatic. The speech as recorded by Polybius includes an appeal to Panhellenic unity and a concomitant desire to prepare against an encroaching barbarian menace (5.104.1-4). This call to action is underscored by a warning that the independence of the Greek world is otherwise at risk of being compromised (9-11). On first glance, then, it seems Agelaus appeals to constructed elements typical of Hellenic discourse, and all our established commonplaces are present. He thereby sustains a tradition we have seen at work since the fifth century. But some are sceptical of this speech, especially on the grounds of its relevance to Polybius' historical programme, since it alludes to Greece's eventual conquerors so early. ${ }^{202}$ Doubtless, Mackil is in any case right to say that "if the speech was genuine, it was prophetic". ${ }^{203}$ For some time it was taken for granted that Polybius, faithful to his methodology, had rendered an accurate account of what was said; and Walbank urges that his version of the speech was based on a contemporary record. ${ }^{204}$ But a different school of thought emerged, best represented by Mørkholm, stating that the speech had in fact been fabricated, since it too closely evoked the supposedly private schemes of Philip and Demetrius of Pharos, and was exaggerated in its invocation of an explicitly Roman danger. ${ }^{205}$ While Gruen, Lévy, and Champion have revived this debate, few now argue from zero-sum positions, that the speech is either altogether correct or altogether fictitious.

\footnotetext{
${ }^{200}$ Agelaus would go on to be elected general of the Aetolian League in the following year.

${ }^{201}$ Holleaux 1923, 162; Walbank 1940, 66; Agelaus' 'party' alignment: Champion 1997, 119.

202 There are also other reasons to be suspicious: Gruen 1984, 322-5, cf. Walbank 1963, 2-3. Some general perspectives: Mørkholm 1967; 1974; Larsen 1968, esp. 357; Gruen 1984, 322-5; Lévy 1994; Champion 1997; Eckstein 2008, 78-83; Dmitriev 2011, 146-51; Waterfield 2014, 38-40.

${ }^{203}$ Mackil 2013, 122.

${ }^{204}$ Walbank 1957, 629, and in Scott-Kilvert 1979, 26-7: "[Polybius] went to considerable pains to obtain authentic versions when they existed. Noteworthy examples of this are his account of the conference held in Locris in 198...for which he evidently had access to a verbatim account, or the speech which the Aetolian Agelaus delivered at the conference of Naupactus in 217".

205 Mørkholm 1967; 1974; and to some extent Gruen 1984, 324. Incidentally, some (principally Realist) scholars actually find there to be evidence for symplokē in Philip's identity as Hellenistic monarch. So Waterfield 2014, 38-40, following Eckstein 2008, 80-9. Consider Eckstein 2013, 257: "Men such as Seleucus II, Antiochus III, or Philip V spent every year of their reigns leading their troops into battle. For Antiochus, that meant 36 straight years in the field; for Philip V it was 42 straight years". See also below, ch. 3.
} 


\section{Roman Hostility and Greek Stereotypes}

It is Dmitriev, however, who has given the most serious attention to the fact that this kind of talk had been commonplace in Greek interstate relations for centuries. ${ }^{206}$ The speech is similar in its content to other speeches both of the third century and before and, as stated, it promotes all of the same topoi. While Polybius' words and phrases will no doubt have helped to reconstruct the speech, Polybian editorialising needs not to have subsumed its central points. In White's Metahistory, for instance, a predominant signpost of the cultural turn, it is maintained that every perspective on society is "shot through with ideology", and this is especially true of contemporary history. ${ }^{207}$ Polybius' historical writing is to some degree necessarily an extension of his politics, and the historian was prone to selectivity and contextualism of various kinds. ${ }^{208}$ Polybius admits, for instance, to being partial to patriotism, and to being moved to write his History in response to Demetrius of Phalerum, the statesman and orator who prophesied that Macedon's supremacy would meet the same end as Persia's, an outcome Polybius was convinced had come to fruition in his lifetime (Polyb. 16.14; 29.21). ${ }^{209}$ But we also know the relationship between history and politics to be transactional, since politicians themselves use history in many ways. ${ }^{210}$ As Clark states, "They make history, as actors; they often write history, as diarists and in memoirs; some even read and study history...Politicians use the past to demonstrate their own historical significance and their fidelity to national traditions". ${ }^{211}$ The synchronisms and synoptic perspectives which so affected Greek history will likewise have bled into Greek politics, especially since oratory, nostalgia, and evaluations of the past remained signal fixtures of its discourse.

The engagement of statesmen with the higher Hellenic identity indicated their homonoia towards other Greeks at the interstate level: the Athenians and the Spartans each sought to invoke Persian enmity before other Greeks to this effect in the fifth century; likewise Demosthenes engaged in this tradition and further invoked Macedonian enmity in the fourth; and so the Aetolians invoked Celtic enmity in the third. The Aetolians could scarcely now carry out a Panhellenic condemnation of Philip, even if they wanted to: the king had brokered the peace conference to begin with - the purpose of which, supposedly,

\footnotetext{
${ }^{206}$ Dmitriev 2011, 146-52.

${ }^{207}$ White 1973, with Lawson 2006, 21.

208 The specific pressures are well pointed out in Champion 2000 and 2004.

${ }^{209}$ Influence of Demetrius' prophecy: Walbank 1957, 19, 22-3.

210 See Clark 2010; Sheldon 2012.

${ }^{211}$ Clark 2010, 1.
} 
was to ratify generally agreed-upon terms - and had recently inherited leadership of Antigonus Doson's reformed Hellenic Symmachy, which for better or worse now included practically every other Greek power. ${ }^{212}$ It was, however, possible to point to an adjacent and severe source of non-Greek kinēsis, and to impute the other Greeks' conventional fears (alongside Philip's ambitions) onto its outcomes.

In arguing for the anachronism of the speech, Mørkholm employed the famous thesis of Maurice Holleaux, that the Romans had no interests in Greece at the time. ${ }^{213}$ In so doing, he fails to recognise that Panhellenic rhetoric stems from moments of internal as much as external crisis, as well from elements of the provincial and chauvinistic. Furthermore, Dmitriev rightly points out that Agelaus' invocation of the barbarian Other hardly anticipates any resistance to Rome, contrary to what Mørkholm suggests, and to what Gruen implies by reading this speech alongside those of 210 and 207, where the Roman danger is presented unambiguously. ${ }^{214}$ Agelaus' references to the western war are generic, applying as much to the Carthaginians as to the Romans, and Eckstein and Grainger acknowledge that his "clouds in the west" metaphor is equally vague. ${ }^{215}$ In some respects this imprecision is striking, since it had been the Romans who crossed the Adriatic to conduct military campaigns in Illyria in 229 and 219, and who had recently contacted the Athenians, Corinthians, Aetolians and Achaeans (Polyb. 2.2.4). ${ }^{216}$ This also explains why the speaker was an Aetolian himself, another factor which some take to enhance the credibility of the speech, since it was their foreign policy which most often looked towards north-western Greece and the Adriatic coast. ${ }^{217}$ Moreover, the Greeks were aware of the fact that the Macedonian court now harboured Demetrius of Pharos, whom in the same year the Romans had unsuccessfully tried to persuade the young Philip, then at the peak of his Hellenic reputation, to extradite (Livy 22.33.3). ${ }^{218}$ News of the Battle of Lake Trasimene

\footnotetext{
${ }^{212}$ That the conference at Naupactus was more concerned with ratification than deliberation: Grainger 2018, 198. See also Larsen 1968, 357-8.

${ }^{213}$ See the assessment of Mørkholm by Champion 1997, esp. 112.

${ }^{214}$ Dmitriev 2011, 149. Gruen's view is further explored below.

${ }^{215}$ Eckstein 2008, 83, esp. n.16, who asserts that Hannibal modelled himself after Alexander the Great, and thereby expressed desire for world conquest. See also Grainger 2017, 198.

${ }^{216}$ So Larsen 1968, 357: "After the Roman intervention in Illyria and the establishment of a protectorate there...many Greeks must have been aware of what might come of this", with Dmitriev 2011, 145-7. It had also been a Roman ship that picked up Aratus of Sicyon in 252: Plut. Arat. 12. Corinth invited the Romans as "honorary Greeks" to the Isthmian games after the Second Illyrian War: see Champion 2000, 428n.11. On the importance of the First Illyrian War for trans-Adriatic politics: Badian 1952; Larsen 1968, 358-62.

${ }^{217}$ Larsen 1968, 357. Agelaus as a surprising mouthpiece for Polybius' views: Walbank 1981, 231. Incidentally, too, a Roman features as an Aetolian proxenos on a list from $263\left(I G \mathrm{ix}^{2} \mathrm{i}, 7 \mathrm{a}, 1.51\right)$.

${ }_{218}$ Philip's popularity: Polyb. 7.12. Philip's letters to Larisa (somewhat inaccurately) recommending a Roman paradigm for generating Greek manpower (see IG IX.2.517; Syll. ${ }^{3} 543$ ), while signalling Philip's
} 
would have been common knowledge to the Greek statesmen at Naupactus, and it is even possible that Demetrius shared Philip's plans with the Aetolian peace party. ${ }^{219}$ Even with these latter considerations aside, what remains is a speech from a Greek interstate conference informed, as so often, by the construction and propagation of a Panhellenic selfimage, here on the part of the Aetolians and similar to that of 279. While Agelaus may ambiguously prefigure the coming of Rome, this simply constitutes part of a greater, generic process of barbarian invocation, a commensurate aspect of reaffirming a state's Hellenic identity and commitment to Greek ideas in times of conflict, whether internal or external.

\section{The Western Invocation in Context}

And yet, some consider Agelaus' invocation even of an undefined western barbarian threat unsatisfying, since it ostensibly represents a novel shift in Greek political interests. Larsen, for instance, asserts that "the Peace of Naupactus marks the end of an era. So far Macedonia and the Greek states had conducted their affairs almost as though there were no powers beyond the Adriatic". ${ }^{220}$ But Hellas included the western Mediterranean world, and we possess plentiful evidence for a Greek cultural tradition of western barbarism, conflated and contorted to fit the same framework as is most often associated with the east, which adequately explains use of the paradigm in this way. Ephorus, for example, whose universal approach to history Polybius sought to emulate (5.33), placed great emphasis on the synchronism of the battles of Himera and Salamis in 480 (cf. Hdt. 7.165-7). ${ }^{221} \mathrm{He}$ even stated that the Carthaginians signed a treaty with Xerxes in order to launch a combined invasion of the Greek world: Hamilcar would wash over Sicily before targeting the Peloponnese. ${ }^{222}$ Pindar had prefigured this exact east-west barbarian pairing in the fifth century, situating Gelon's victory over the Carthaginians beside those of the mainland Greeks over the Persians, and stating that the battle of Himera had "delivered Greece from grievous slavery" (Pyth. 1.72-8). ${ }^{223}$ And although Aristotle went on to write against this pairing in his Poetics, sceptical of the connectedness of the actual battles, in so doing he seems to have been alluding to a commonly held belief in his day (Poet. 1459a). ${ }^{224}$ The

admiration for Roman institutions (as Gruen says), should also surely be taken as evidence of a degree of Roman familiarity.

219 See Champion 1997, 119.

${ }^{220}$ Larsen 1968, 359. So too Champion 1997, 112-7; cf. Waterfield 2014, 41.

${ }^{221}$ See $\mathrm{FGrH} 70 \mathrm{~F} 186$.

${ }^{222}$ Few modern scholars now take this as a statement of historical fact: Asheri 1988, 774.

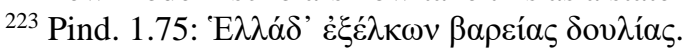

${ }^{224}$ On the ambiguities of Aristotle's comments, see the commentary of FGrH $70 \mathrm{~F} 186$. 
rosy conflations of Pindar and Ephorus were later sustained and intensified by Diodorus, who considered the Greeks' successful resistance to this supposed pact to have been an act of divine providence (9.24.1). ${ }^{225}$ And all of this to say nothing of Timaeus, the third-century Sicilian historian who wrote in Athens, and against whom Polybius designated himself both a rival and continuator. ${ }^{226}$ Timaeus popularised the campaigns of Pyrrhus of Epirus and Agathocles of Syracuse, who together engendered against themselves the signing of a Roman-Carthaginian treaty early in the third century, triggering Rome's first crossing into Sicily. ${ }^{227}$ "It is indeed possible to argue", states Pearson, "that Timaeus understood the rise of Rome as well as Polybius", and Gruen acknowledges the marketability of his history's Roman elements to a Greek audience. ${ }^{228}$ In the case of Agelaus, Polybius seems to be reporting a common cultural assumption which distorted the rationality of Greek behaviour: Greeks are allotted a distinct position in the world; but non-Greeks are able threaten that position, especially when the Greeks are overly divisive and insufficiently wary.

\section{Barbarian Utility}

Even if we were to believe that the western Mediterranean was of little importance with respect to the materialist maps of mainland and Peloponnesian Greeks, it nevertheless retained its utility with regards to their cultural and mattering maps. The west was as versatile as the east - if not more so once the Persian Empire had been conquered and Hellenised - in its receipt of barbarian characterisations. The barbaros paradigm continued to serve as a flexible medium through which Greek states could signal their fidelity to the precepts of Hellenism. Moreover, considering the themes of Agelaus' speech in broader rhetorical and historical context frees us of the need to denote 217 as a signal shift in the Greek worldview, such as is claimed by Larsen, Champion, and to some extent even Polybius. While it is an admirable predisposal, Mørkholm may be overzealous in seeking Polybian anachronism by reading Agelaus' speech from a metrocentric view towards Rome

\footnotetext{
${ }^{225}$ Diodorus, as it happens, claimed the battle of Himera occurred on the same day as the battle of Thermopylae. Timaeus sits uneasily in between Ephorus and Diodorus, but we cannot make much of what we have of him: Pearson 1987, 135-9. Also, generally, the Greeks' reverence of the divine is often understated. Agelaus' speech is itself not lacking in divine invocation (Polyb. 5.104.11). Polybius and religion: Walbank in Scott-Kilvert 1979, 24-5.

${ }^{226}$ On Polybius' disdain for Timaeus: 12.23, 25i-26b contra 12.11.1-3. Walbank 1957, 9-12; Luce 1997, 1101 .

${ }^{227}$ Luce 1997, 110.

${ }^{228}$ We are told about Timaeus' Roman interest by Aulus Gellius: see Pearson 1987, 50n.49; for the quote: 51. See also Gruen 1984, 254.
} 
and by seeing explicit resistance where there is none. Gruen could well be right to say that no distinct Hellenic image of Rome took shape during and after this time, nor indeed any unified Hellenic western policy. ${ }^{229}$ But this does not matter. What the Greeks had already possessed for centuries was an ideology, galvanised in one respect by internal pride and agonistic conditions, and in another by ignorance and parochialism, which cultivated a generic and politically useful exogenous stereotype with which to stir Hellenic interstate attitudes. Gruen concedes as much in passing, and it should not be forgotten that, as Mitchell says, while in the face of most barbarians the Greeks were "transparently not united in their resistance", the war against the barbarian was a dynamic and versatile Panhellenic theme, onto which any state - even Greek - could be grafted. ${ }^{230}$ The Carthaginians had long been the victims of this kind of characterisation, and through them, the western periphery of the Greek world long occupied a conceptual space similar (if less archetypal) to the eastern one - that is, a barbarian, anti-Greek, and dangerous border against which Hellenism demanded clear distinction.

Militarily, the Aetolians will have been wary of Philip's intentions and reticent about his sudden peace on the basis of status quo. And so, diplomatic manoeuvring was an effective means for them to strengthen their position in the interim. As with many historical appeals to Panhellenic themes, therefore, Agelaus sought principally to repair his state's reputation amongst the Greeks, to realign it, and to reaffirm that the Aetolians were thoroughgoing Greeks themselves, sharing the same basic concerns at a time where Philip's ambitions drew him away from Greek affairs, towards Illyria and, later, into a war with Rome. It may be anachronistic to believe that the Greek powers took policy actions with Rome in mind in 217 , but such a finding is requisite neither to the power nor to the historicity of the speech of Agelaus. The traditional Greek idea of defending freedom by way of a call for unity was commensurate with Aetolian interests. An interstate setting resembling that of a Common Peace is a prime location for this kind of talk, and it is important to note that, although such discourse is preoccupied with the of dangers of barbarism, it is inward-looking as much as outward-looking. Whatever we make of the speech at Naupactus in 217, our assertions must remain speculative. It may be that Polybius mirrored early reimaginations of events, forged perhaps between 210 and 206-something which in its own right could have instrumental bearing on the subsequent construction of identities and narratives, such as

\footnotetext{
${ }^{229}$ Gruen 1984, 325.

${ }^{230}$ Gruen 1984, 324; Mitchell 2007, 10-9.
} 
has been alluded to with the likes of Simonides' Plataea elegy, the production of Aeschylus' Persians, Demosthenes' post-Chaeronea speeches, and the Aetolian institution of the Sōtêria. But in any case, some insufficiencies behind discarding the value and historicity of the speech of Agelaus are now at least apparent.

\subsection{The Aetolian War (211-206)}

\section{Greco-Roman Relations in the First Macedonian War}

A range of Greek attitudes towards Rome does plainly emerge, however, between the years 211 and 206. During this time, Greek states started to configure the Romans as a binary alternative to Macedon as the threat to Greek freedom, and so as the state against whom other Greeks might shape their interests. These years mark the latter half of the fitful socalled First Macedonian War, whose initial stages (c.215-211) consisted of skirmishes between Philip and the Romans over territories in Illyria. Philip's treaty with Hannibal (the draft of which the Romans dramatically intercepted on its way back to Greece) technically committed the Greek alliance to the defeat of the Romans as well, but little was done in practice to implicate Greece proper until 211. ${ }^{231}$ And while scholars scorn the prospect of an Italian invasion by Macedon at this time, social and systemic pressures clearly compounded Roman fears, and compelled the Romans, for their part, to act on basis of them: Philip was a descendent of Pyrrhus and had already garnered a reputation for bold military gambles. Upon discovery of the Macedonian-Carthaginian treaty in 215, the senate bolstered the Adriatic fleet of P. Valerius Flaccus, instructing him to gather intelligence on the probability of a war with Macedon (Livy 23.38.9). ${ }^{232}$ If the intelligence was deemed to be sufficiently distressing, then M. Valerius Laevinus - the praetor stationed in Brundisium (whose grandfather, as it happens, Pyrrhus defeated at Heraclea in 280) - would attempt to contain Philip in the Balkans by taking the Roman fleet to Illyria. By 214, Laevinus had already executed this failsafe, but it had not stopped Philip from securing the port city of Lissus by land the following year, nor Hannibal from gaining Tarentum in 212 (Polyb. 8.15-6, 26; Livy 24.13). Furthermore, Livy reports that the Syracusans, having also thrown in their lot with the anti-Roman coalition, now invited Philip to intercede by sending him an envoy which the Romans again intercepted, much to their growing distress (Livy

\footnotetext{
${ }^{231}$ On the treaty of alliance between Philip and Hannibal: Waterfield 2014, 45-6.

${ }^{232}$ Many scholars stress the importance of Roman fear on policy making here, despite the low probability of a Macedonian invasion. So Badian 1958, 56-7; Rich 1984; 130, Eckstein 2008, 86-7; and Waterfield 2014, 47-9. Philip's character: Eckstein 2008, 78, 80, 85, 144-5, 224. See also Larsen 1968, 357. Cf. Zon. 9.15
} 
25.23.8-9). ${ }^{233}$ With his command extended, Laevinus thus went to Greece and met with Aetolian officials in 212 in the hopes of creating a distraction for Philip, and in the next year signed the first formal, written agreement between Rome and a Greek state. The Aetolians took some convincing, on account of Philip's strong position in Greece and Illyria, and the talks were protracted and difficult. However, Roman victories in the summer of 211 appear to have strengthened the resolve of the Aetolians to consent to an alliance in the autumn. Elis, Messene, Sparta, Pergamum, and the Illyrian dynasts Pleuratus and Scerdilaidas were later invited to join.

\section{Hellenic Conflict}

Indeed, most scholars now speak of the First Macedonian War (the name itself a by-product of metrocentric explanations of Roman imperialism) as comprising two separate conflicts: the war between Philip and Rome, waged from 215 to 205; and the war between Philip and Aetolia, waged from 211 to $206 .^{234}$ The latter of these conflicts the Greeks themselves called the "Aetolian War", and it was in effect a revival of the Social War which Philip had abruptly ended at Naupactus in $217 .^{235}$ Alongside the Aetolian war party's dissatisfaction with that peace (which, by maintaining the status quo, prohibited not only their recovery of Phthiotic Thebes and territories in Acarnania but also limited their fiercer, stereotypical drives towards warmongering and piracy), much of their reasoning for going to war lay in the league's traditional opposition to Macedon. Looking to assert influence in a similar region, the two powers often clashed, not unlike the Achaean League and Sparta. ${ }^{236}$ Both Macedon and the Aetolian League sought to monopolise the Amphictyonic Council in order to acquire influence and cultivate a Panhellenic self-image. The Aetolians had also fought alongside Athens during the Lamian War. Now, the operative clause of the Aetolians' treaty with Rome offered great prospects for expansion, stipulating that they would receive all the towns which they captured south of Corcyra (whereas the Romans would carry off Greek prisoners and other moveable booty: Livy 26.24). ${ }^{237}$ The spoils of

\footnotetext{
${ }^{233}$ Badian 1958, 56.

234 That the First Macedonian War "misnames" the conflict: Gruen 1984, 440; Green 1990, 288; Eckstein $2008,93$.

235 This is derived from Livy, who here depends on Polybius for reconstructing his account of events (33.10.10). The Aetolians themselves called this war the Aetolian War. For their aims: Polyb. 9.30.8-9.

${ }^{236}$ As recently as the Social War, Philip had advertised the liberation of the Amphictyonic Council from Aetolian control as a war aim to his Greek allies: Larsen 1968, 336-7, cf. 303-26.

${ }^{237}$ We possess fragments of the treaty; see Zanin 2017 for the text, apparatus, and translation. On the prominence of Roman ideas: Badian 1958, 293-4. Green 1990, 300n.100 provides good bibliography about the treaty arrangements. Consider also Hammond and Walbank 1988, 400-1, where it is described as "a treaty of expediency between unscrupulous partners".
} 
any joint operations would be shared, though the Aetolians again had rights to all territorial rewards. Rome's arrangements and subsequent actions show that they were not interested in winning Greek favour through this treaty: it was primarily an expedient with which to keep Philip busy as they struggled for their lives against Hannibal. ${ }^{238}$

\section{Roman Cynicism}

The Romans' substantive arrival on the Hellenic stage was marked, therefore, by their pursuit of a transparently cynical policy: to consciously act at cross-purposes to the stability brought about by the Peace of Naupactus. ${ }^{239}$ Throughout the course of the Aetolian War, therefore, and at the expense of several cities, the Romans and Aetolians were ruthless. Aetolian levies immediately massed for an invasion of Acarnania (it was stated in the treaty that Rome would help them with this), compelling the Acarnanians to send their noncombatants to Epirus for safety, and to swear a drastic oath in response that they would fight to the death. ${ }^{240}$ Philip raced south in order to disrupt the Aetolians' plans, but this did not prevent coastal Acarnanian seizures by Laevinus, nor the Aetolians' capture of Oeniadae later in the year. ${ }^{241}$ Roman forces then nearly seized the island of Zacynthus and in early 210 succeeded in taking Anticyra, which had a valuable port in the gulf of Corinth. Laevinus plundered the city and sold its inhabitants into slavery, before giving it over to the Aetolians (Livy 26.26). While this alliance had been engendered through the aggression of Philip, the initial victims of the Roman-Aetolian campaigns were several of his Greek allies.

In 210, Laevinus' command was replaced by that of P. Sulpicius Galba, who cemented Rome's reputation for cruelty and cynicism. Early on, he sacked the island of Aegina, then a member of the Achaean League. He ransomed its wealthiest citizens (enslaving the rest) and gave it over to the Aetolians, who in turn sold it to Attalus of Pergamum for a fire sale price, as part of their arrangements to secure his services as stratēgos for 209 (Polyb. 9.42, cf. 22.7.9; Livy 27.32). ${ }^{242}$ The next year, Philip defeated Pyrrhias, Attalus' Aetolian colleague, in two battles at Lamia, but Attalus and Galba sacked Opus and Oreus in 208 (Livy 28.7.3). The Romans and Pergamenes also raided islands in the Aegean, and Galba

\footnotetext{
${ }^{238}$ This thesis follows the consensus treatment of the years 211-205 seen in Holleaux 1921, Badian 1958, 5563, Eckstein 2002 and 2008, esp. 88-118, Rosenstein 2012, 179, and Waterfield 2014, 49-57. The Roman policy was characterised by the strategic, defensive need of keeping Philip distracted in Greece.

${ }^{239}$ Champion 2000, 428.

${ }^{240}$ Eckstein 2008, 88.

${ }^{241}$ Waterfield 2014, 51-2. Philip would later reclaim these territories, but not for a few years.

${ }^{242}$ The island was sold for thirty talents: Waterfield 2014, 53.
} 
moved south to sack Dyme, one of the Achaean League's founding poleis, again selling the inhabitants into slavery (Polyb. 2.41, 4.59-60; Livy 32.22.11). ${ }^{243}$ Discussing Galba's career as the Roman commander in Greece, Champion wrote that the policy he employed "may best be described as one of terrorism". ${ }^{244}$ But despite these moves, Attalus was suddenly forced out of the war, owing to the combination of a storming counterattack by Philip at Opus and a concurrent invasion of Pergamum by his brother-in-law, Prusias of Bithynia. ${ }^{245}$ After this, our sources and our narrative for 207-6 become troublesome: Polybius' account is no longer extant (save for a fragment which is discussed below); Eckstein has pointed out that Appian's Macedonicus, while useful, is hazardous, since its earlier chapters contain factual errors; and Livy opted to ignore Greek affairs since, he says, the Romans at this time became militarily inactive in Greece (29.12.1, 32.21.17, 36.11.11). ${ }^{246}$ Even so, Livy's statement remains indicative of a clear pattern of Roman military activity in Greece between 211 and 205, as sporadic as it was violent: the Roman policy consisted of large moments of inaction, punctuated by episodes of sudden brutality.

\section{Greek Peace Talks (209-206)}

In the course of this war, therefore, Greek statesmen quickly detected that Rome was acting at cross-purposes to Greek stability. Greek states, both belligerent and non-belligerent, sought several times throughout 209, 208, 207, and 206 to bring about a cessation of intraGreek hostilities, becoming increasingly disillusioned about Roman behaviour. In 207 and 206, the Aetolians despaired of Roman aid and themselves grew disenchanted. Moreover, Philip's land victories in 208 had enhanced the prestige of Macedon's armed forces and had deprived the Aetolians of their closest ally, Attalus. In the Peloponnese, Philopoemen had also reformed the Achaean army and was inflicting defeats on Sparta, most severely at Mantinea in 207. So, in that year, two sets of peace talks took place at Heraclea. The mediations of 207 constitute the only talks between 209 and 206 where a Roman presence is explicitly attested; and here, Galba tried to sabotage them, despite Philip's supposed attempts to achieve (perhaps for the only time before 205) a comprehensive peace which

\footnotetext{
${ }^{243}$ Walkbank 1981, 233. Philip would later go to great pains to recover this city and emancipate its inhabitants.

${ }^{244}$ Champion 2004, 52.

245 The withdrawal of Attalus should not be understated. He was a closer and more trustworthy ally of the Aetolians than was Rome. On their friendship: McShane 1964, 100-2 and 106-7.

${ }^{246}$ Effective criticism is conducted on App. Mac. 3 by Eckstein 2008, 105-9. There is also some evidence in Dio frg. 57.58 and Zon. 9.11.
} 
included Rome. ${ }^{247}$ Galba claimed that he lacked the powers necessary to commit Rome to peace, but wrote to Rome that the ongoing war was in their interests, and then to his Greek allies that the Roman position was that it must continue. ${ }^{248}$ A second peace attempt quickly followed where the ambassadors, furious with Roman behaviour, shouted Galba off the rostra when he rose to speak. For reasons which have not survived, however, this peace attempt ultimately failed. ${ }^{249}$ It was only after Rome continued to withhold support and once Philip had launched a major invasion of Aetolia in 206 that the exhausted Aetolians at last negotiated a peace that was separate from Rome, contrary to the stipulations of their treaty in 211 (Polyb. 11.7.2-3). ${ }^{250}$ It would be only a decade more until the Aetolians themselves lamented that the Greeks had exchanged Philip for the Romans as their despot (Polyb. 18.45.6).

\subsection{Panhellenism and the Mobilisation of Culture}

\section{The Anti-Roman View}

The Aetolian War alarmed most Greeks on account of its especially brutal conduct, brought on in large part by the cynical character of the Roman-Aetolian treaty. Specifically, its operative clause appalled many in the Greek world, "which", as Badian put it, "had left such customs behind in the development of its civilization" —or at least characterised itself as having done so (Polyb. 9.34.9-10, 36.10, 11.5). ${ }^{251}$ Near at hand, the calamitous fate of Syracuse - practically destroyed after a drawn-out Roman siege in 211 - must have looked as if a solemn premonition: Roman military behaviour in Greece proper, though abortive, had been equally ruthless (Polyb. 8.37; Livy 25.24-5). ${ }^{252}$ Horror stories are said to have grown up around events in Sicily and Southern Italy; and Polybius censured Marcellus and Fabius Maximus for carrying off massive quantities of gold, silver, art, and enslaved Greeks from Syracuse in 211 and from Tarentum in $209(9.10,39.2-3,10.15) .{ }^{253}$ Waterfield is right to emphasise that the "degradation of a plundered town or city was moral as well

\footnotetext{
247 There is some confusion about the mediations of 208, since Roman envoys were present at Heraclea (Polyb. 10.42.4). The ambiguities are well assessed both in Eckstein 2002, 269, 278-80, and 2008, 100-3.

248 This claim from App. Mac. 3 is supported by Holleaux 1935, 36n.3 and vindicated by Eckstein 2008, 106, despite Schmitt 1957, 209.

${ }^{249}$ On this, see Eckstein 2008, 110-1.

${ }^{250}$ On the arrival of P. Sempronius Tuditanus: Eckstein 2008, 104-5, 111.

${ }^{251}$ Badian 1958, 56-7.

${ }^{252}$ See also Plut. Marc. 14-21.

${ }^{253}$ Champion 2004, 50. See also Livy 25.40, 27.16.7-8. The displacement of Italian Greeks will have ensured these stories were widespread: Tarentine mercenaries, for instance, can be found serving under Philopoemen at Mantinea in 207.
} 
as economic: its pride and sense of identity were often closely tied up with its public monuments". ${ }^{254}$ Rome's severe treatment of the states in Magna Graecia was later invoked by the Macedonians at the Panaetolica of 199 as a reason why the Aetolians should remain at peace with Philip during the Second Macedonian War (Livy 31.29.4-16). And in Greece proper, we have seen that many Greek states spoke out between 210 and 206, whether directly against the Roman-Aetolian alliance or for generally restoring the more peaceable conditions brought about after 217. Two speeches in particular, preserved in Polybius one by an Acarnanian named Lyciscus in 210 (Polyb. 9.28-39) and another by a Rhodian most likely named Thrasycrates in 207 (Polyb. 11.4-6) - appear to have promulgated fiercely anti-Roman sentiments at the interstate level.

Lyciscus went before the Spartan assembly in order to speak against an Aetolian delegation, led by an ambassador named Chlaeneas and eager to attach Sparta to their alliance with Rome. Bordering the western territory of Aetolia, the Acarnanians bore the brunt of Aetolian raiding, and were at this time buckling under the pressure of a RomanAetolian pincer. ${ }^{255}$ Such conditions naturally hardened the Acarnanian relationship with Macedon, to whom they remained loyal until their mutual collapse following Perseus' defeat at Pydna in $167 .{ }^{256}$ Lyciscus, therefore, had strong motivation to remind the Spartans of the 'benefactions' done them by Antigonus Doson, owing to whose magnanimity, he claimed, the Spartans were in the first place now empowered to deliberate on whether or not to challenge Macedon and her Greek allies (Polyb. 9.36.1-5, esp. 4, which talks of Doson's restoration of to patrion politeuma). Unsurprisingly, the speech abounds with recurrences to the same old Panhellenic themes, and it is especially sensitive to history and continuity. Lyciscus recounts the earlier favours bestowed unto the Greeks by Philip II and Alexander the Great, as well as by the Spartans themselves. ${ }^{257}$ Conversely, he then draws direct parallels between Rome and Persia: Xerxes is invoked in the Roman mould, and the Aetolians are cast as his Medising Theban allies (9.38-9). ${ }^{258}$ The Romans are called barbaroi (9.37.5), and thus Aetolian arrangements with them are labelled allophylon foreign, and belonging to another tribe (9.39.3). Lyciscus urged that it would be

\footnotetext{
${ }^{254}$ Waterfield 2014, 78.

${ }^{255}$ See above. By this time, the Aetolians had already seized Oeniadae and Nesus in Acarnania, as well as (elsewhere) Anticyra, which Lyciscus supposedly mentions himself (Polyb. 9.39.1-2).

256 The Aetolians and Acarnanians had in fact signed treaties of both alliance and isopoliteia in the 280s, which Lyciscus fails to mention. On the history of the Acarnanian League: Larsen 1968, 264-73.

${ }^{257}$ That the importance of historical events over abstract rhetoric is an argument for historicity: Usher 2009, 495.

${ }^{258}$ The tokens indicative of Greek poleis' submission to Persia are evoked at 9.39.1 (cf. Hdt. 7.132).
} 
unbecoming of the Spartans, who had spearheaded the Greeks' legendary defence of Thermopylae (9.38.4), who sought to reprimand the Thebans for their Medism (9.39.4), and who were presently indebted to Macedonian clemency, to take up the cause of the barbarian Romans now (9.36.5-6). Anticyrean Greeks had already been carried off by this alien people (9.39.9); and the Aetolians, in their complicity, had abandoned the principles of Hellenism altogether. All Greece might soon be set to suffer a similar fate: "be on your guard against an attack from Rome; suspect the treachery of the Aetolians; unite your hopes for the future with those of Achaea and Macedon" (9.39.6-7). Such remarks, while typical of the alarmist tone of Greek diplomacy, signify an intensification of anti-Roman sentiment from that which we saw in 217 , showing the Romans as by now incorporated into the familiar Greek politics of cultural alienation.

A similarly vicious speech emerges in the penultimate year of the Aetolian War. Unfortunately it is fragmentary, but we can surmise that it belongs to one of the conferences of 207 (most likely the latter). ${ }^{259}$ Twice in this year it was tried by several non-combatants - Rhodes, Ptolemaic Egypt, Chios, Mytilene, Athamania and Byzantium - to bring about a cessation of hostilities. Conditions favoured new Greek peace initiatives: as Livy states, Rome had hitherto been largely absent from Greece; and Philip, while continuing to tighten his chokehold over the war, was clearly more open to peace talks than he had been in $208 .{ }^{260}$ Throughout the course of the speech, Thrasycrates is extraordinarily hostile towards the Romans and, more specifically, towards the alliance which the Aetolian League had struck with them. The Romans are once more called barbaroi, their actions described as barbarikon, and they are further ascribed the detestable Polybian traits of paranomia and aischyne (Polyb. 11.4.8, 5.2, 5.6-7). ${ }^{261}$ In signing a treaty with them (whose clauses, Thrasycrates reiterates, had already been put into grisly action at Anticyra, Aegina, Oreus, Dyme, and elsewhere), the Aetolians were creating the pretext for a committed Roman intervention into Greek affairs, and maybe even their domination of them (11.6.1-5). Thrasycrates also reiterates that it is the Greek allies of Philip who were suffering from

\footnotetext{
${ }^{259}$ Insofar as this account is preceded by the clockwise news of Hasdrubal's defeat at Metaurus river in June 207, it propbably belongs to the subsequent 'Events in Greece' narrative of that year. Reasons for attributing the fragment to the second mediation attempt (at the Panaetolian assembly in autumn): it fits the anti-Roman tone of the speeches which Appian states ambassadors gave there; and such a tone would not be consistent with an attempt to bring about comprehensive peace, which was the goal of the spring meeting. For more on attribution: Walbank 1967, 274, Eckstein 2002, 288-9; 2008, 103-7. See also Derow 2003, in Erksine and Quinn 2015, 27-8.

${ }^{260}$ Eckstein 2002, 283-4.

261 Eckstien 2002, 290: The latter traits are reserved by Polybius "for the worst categories of people (criminals, Celts, the unruly mob)".
} 
Roman-Aetolian attacks (11.5.5), and he incessantly stresses $(11.4 .4,9,5.1,9,6.9)$ that the freedom and safety of all Greece is being jeopardised by their collaboration.

\section{The Consistency of the Anti-Roman Position}

These speeches appear to seriously advance the explicitness of Greek acrimony towards Rome and Aetolia in the final decade of the third century. Taken together, they help to stress an understated point about Greek attitudes at the time: it was not only Philip's Greek allies, but also the neutral states who saw the Romans as externally endangering (and the Aetolians as internally undermining) Greek security. Indeed, for much of the war the Roman-Aetolian alliance transmitted an attitude that was "not serious" about peace. ${ }^{262}$ Many Greeks tacitly sanctioned Macedon's role as the defender of Greek stability and freedom; in the case of Lyciscus, such sanction was explicit. The Macedonians were only too eager to cultivate this reputation: at Aegium in 209, an almost certainly Macedonian speaker warned the Aetolians that they were bearing the brunt of Philip's military might on behalf of interests that were common neither to the Aetolian League itself, nor to the rest of Greece. ${ }^{263} \mathrm{He}$ urged that the Aetolians were instead being used by the Romans, who, like a heavy phalanx first awaiting the exposure of the lightly-armed forces (i.e., the Aetolians), waited either to walk away unscathed, or else to claim credit for their victory (Polyb. 10.25.1-5). The Romans would overwhelm all Greece if the Aetolians continued to serve as conduits for their will. The Macedonians thus likewise sought, through fear and anger, to detach the Aetolians from their alliance with Rome, and to realign them with the traditional course of settling Hellenic affairs internally (in this case, of course, including Macedon). ${ }^{264}$ Amongst others, Derow saw the widespread dissemination of this kind of view as being governed by the disruptive conditions in Greece at the time:

The war went on, and revulsion at the nature of its conduct grew apace. Nothing like this, with populations being enslaved, had been seen in Greece for a long time (cf. Tarn and Griffith 1952: 80-2), nor had such 'barbarians' and 'aliens'. 265

And yet, as is the case with Agelaus, much is made of what Lyciscus and Thrasycrates had to say about the prospect of a Roman subjugation of Greece, and the "snug fit" of their

\footnotetext{
262 "Not serious" about the peace: Waterfield 2014, 45-54.

263 On this conference: Eckstein 2008, 96-7.

${ }^{264}$ Eckstein 2008, 96.

${ }^{265}$ Derow 2003, in Erskine and Quinn 2015, 26, with Waterfield 2014, 57-8.
} 
speeches into the Polybian programme once again raises the eyebrows of more cautious historiographical scholars. ${ }^{266}$ Some accuse Polybius of having invented an objective Hellenic attitude towards Rome, and Gruen states that Greek interest did not run deep, even amongst the Greek elite, until after 200. ${ }^{267}$ Even after the chaos of the Aetolian War, Rome's disruptive stint in Greece is deemed not to have left any form, or forms, of impression on Greek minds. ${ }^{268}$ In light of prevailing attitudes of Greeks towards nonGreeks, however, coupled now with the tumultuous years of 211-206, it is difficult to consider this position tenable. The following section will show that a series of different conceptions of Rome had in fact already formed in the final decade of the third century, most of them - but critically not all - negative. That an exclusive and therefore suspicious pattern of anti-Roman feeling is presented in the Histories is an inference that, while perhaps steered by Polybius' prejudices, is ultimately drawn from the reader.

\section{Competing Panhellenisms}

Firstly, to the historicity and accuracy of the speeches: while Gruen maintains that they were merely contrived in order to falsely anticipate a broad view of Rome as an ascendant power, Walbank repeatedly stresses that we may take the main thrusts of Polybian speeches as faithfully reflecting contemporary attitudes — even if coloured by his choice of words. ${ }^{269}$ Once again, we know that, on the one hand, it was Polybius' project to offer an account of Roman imperialism, and doubtless his writing style smooths speeches together with this in mind: nowhere is this clearer than in Lyciscus' reiteration of the clouds in the west metaphor (Polyb. 9.37.10). It may also be the case, as Champion believes, that in these particular speeches Polybius capitalises on contemporary anti-Roman sentiments to indulge in some oblique personal criticisms. ${ }^{270}$ But Champion is likewise at pains to uphold that this does not endanger the historicity of the speeches. Once again, especially in the

\footnotetext{
${ }^{266}$ So Gruen 1984, 323, 355, Waterfield 2014, 58; cf. Pedech 1964, 280-2; Eckstein 2002; Derow 2003; Dmitriev 2011, 147-51.

${ }^{267}$ Gruen 1984, 355; Waterfield 2014, 58, who reduces the speeches to Polybian "spin".

${ }^{268}$ So Gruen 1984, 321-5: "The orations highlighted in Polybius' pages owe more to rhetorical propaganda and to the historian's conception than to the realities of the third century. The future mistress of the Mediterranean was not yet foreseen. No distinct Hellenic image of Rome had taken shape".

${ }^{269}$ Gruen 1984, 322; cf. Walbank in Scott-Kivlert 1979, 23-7; and 1981, 230-4. Consider Walbank 1957, 13: "Polybius is therefore entitled to our confidence that he made a determined effort to discover what was actually said $\kappa \alpha \theta^{\prime}$ ö $\sigma o v$ oĩóv $\tau \varepsilon \pi \circ \lambda v \pi \rho \alpha \gamma \mu o v \eta ́ \sigma \alpha \varsigma$, and that any failure here and there is due to practical shortcomings rather than a deliberate betrayal of principle". Nevertheless, in the speech of 210 , the oṽ $\tau \varsigma$ $\pi \tilde{\omega} \zeta$ at 9.32 .2 indicates that it is not a literal transcript.

${ }^{270}$ Champion 2000. It is important to note that their philhellenism was deemed to have increased over time.
} 
case of Sparta in 210, Polybius probably possessed genuine records of what was said. ${ }^{271}$ Even if we are sceptical of the presentation of the speeches - or even of the speakers themselves - it is worth resisting the more extreme urge to reject the substance of the sensibilities which they embody altogether.

More importantly, what is all too often overlooked in the Greek speeches of the time is most clearly illustrated in the case of Chlaeneas and Lyciscus: that both sides in the Aetolian War are shown to have presented their interests through the prism of Panhellenism and defending the right to claim Greek affairs for themselves. ${ }^{272}$ And it is evident that these alternative Panhellenic perspectives, as in earlier periods, targeted more than one kind of barbaros. We must, in other words, consider Polybius' presentation of Aetolian diplomacy (as embodied in the speech of Chlaeneas) alongside its Acarnanian, Rhodian, and Macedonian counterparts, if we are to gain a more balanced picture of how Greek ideas were utilised at the interstate level. Writing about the focalisation or "gaze" of the Histories, Davidson states that "often it is only possible to talk of what appears in Polybius", and the moments where he tells us little often demand the greatest attention. ${ }^{273}$ No doubt the comparative lengths of the speeches as reported indicate Polybius' sympathies: he favoured the Acarnanian proposition, and in so doing falls in line with the stance of the Achaean League. ${ }^{274}$ Here Polybius concedes his prerogative to show partiality in the name of patriotism (16.14); but the historian's partisanship to a particular conception of Hellenic interest - here qualified by his Achaean identity - neither indicates that this conception is altogether fictional, nor that it was the only conception available in the Greek world. Despite the brevity of Polybius' account of the speech of Chlaeneas, it is clear that the Aetolians were engaged in exactly the same discursive practice as the Acarnanians and, presumably, the Achaeans. The Greek-barbarian polarity remains central; it is merely the referents of the barbarian labels that are different.

\footnotetext{
${ }^{271}$ See Walbank 1967, 162-3; Eckstein 2013, 332n.91; Usher 2009, 495. As Walbank has shown (163), the fact that Machatas' speech at Sparta in 220 has some of its points indirectly refuted by Lyciscus is not an argument against the speech's historicity. See also Dmitriev 2011, 150.

272 Studies of Panhellenic attitudes in this period which focus exclusively on Rome and subordinate Chlaeneas: Gruen 1984, 321-5; Champion 2004, 30-63; Dmitriev 2011, 147-51.

${ }^{273}$ Davidson 1991, 10.

274 The speech of Chlaeneas is less than half the length of that of Lyciscus: Walbank 1967, 162-3, contra Eckstein 2013, 331. On patriotic history: Luce 1997, 118.
} 


\section{The Anti-Macedonian View}

In Demosthenic vein, Chlaeneas recasts the barbarian focus not on Rome but on Macedon. The speech opens with a scathing attack on the conduct of Philip II, who terrorised the Greeks in the fourth century and purposefully reduced Spartan dominions (Polyb. 9.28.68). Moreover, Chlaeneas claims that Philip was only lenient in his treatment of Athens because he hoped it might later ease his subjection of other Greeks. Chlaeneas then states that Alexander the Great destroyed Thebes because it preserved "a spark of Hellenic life", despite being told elsewhere that Thebes was destroyed on the initiative not of Alexander, but of his council of Greek allies (Diod. 17.14; Arr. 1.9.6-9; Just. 11.3.6-9, cf. Polyb. 38.4), and that the Hellenic Alliance of the fifth century resolved to sack the city on account of its Medism (Hdt. 9.86-7). ${ }^{275}$ The dissidence and contingence of Greek attitudes towards Philip II (and indeed Thebes) is of course well known, and has been touched on above. In this instance, it was better suited to Chlaeneas' aims - in trying to align Aetolia's political interests with Sparta's - to invoke a model of Macedonian rather than Persian or Roman barbarism. We are well to remember that the Aetolians joined Thebes in revolt against Macedonian rule and were afterwards stalwart allies of Athens during the Lamian War. ${ }^{276}$ Aetolian Panhellenism, it is apparent, was in effect an extension of the negative Panhellenic model best encapsulated in late fourth-century Athenian rhetoric.

The elastic vocabulary of Panhellenic language let familiar conceptual space be used in order to accommodate a diverse range of lived experiences. Cultural identities are invoked in support of political claims; and where common ground is found, it is utilised. It should be reemphasised that the coexistence of separate identities and hierarchical categories of interest does not necessarily entail that one set is any more real than the other. Gilbert, for example, has suggested that there is no one basic identity which can stand alone outside of a particular context. ${ }^{277}$ It is rather the importance which people attach to that context which qualifies the authenticity of the relevant identity, and of the relevant interests that are rooted in it:

\footnotetext{
275 Justin's account of this is even more dramatic: the Greeks swore a solemn oath to destroy the polis once the Persians had been defeated (11.3.10). Chlaeneas likewise makes no mention of Alexander's refoundation of Plataea on account of its services to Greece in 479, said to have been proclaimed at the Olympic games of 328 (Plut. Arist. 11.9; Alex. 34). The chronology on this claim is, however, troublesome: see Flower 2000a, 96n.3

276 Theban-Aetolian revolt: Mackil 2013, 88-9; Lamian War: 92-3.

${ }^{277}$ Gilbert 2010, 5-14.
} 
Asked out of the blue, as it were, 'Who are you?' the right, if suspicious sounding, reply may well be, 'What do you want to know for?' For until one knows the context of the question one has no idea how to answer it. ${ }^{278}$

An inter-polis context emphasises different - but no less legitimate - interests than an intrapolis one. Sparta's interstate (or Hellenic) identity is not invalidated, in other words, by the coexistence of a domestic or local identity, even if its interests are found in many respects to be contradictory. It has well been analysed, for example, how Sparta was better set to influence the Peloponnese through a treaty of pragmatism with Aetolia and Rome; but few now dwell on why they wanted to do this, and how their decision was affected by citizens' lived experiences and senses of history, reputation, or political inheritance. ${ }^{279}$ However tempting it may be to suggest that Sparta's material interests were somehow the more "basic", they did not exist independently of their more ambiguous and discriminating ideas - equally real, but less tangible - which were placated by Chlaeneas' traditionally antiMacedonian politics of Panhellenism.

Whatever the event, in generating an image of the Greek view of Rome at this time, it has become common to adduce only the anti-Roman speeches of Agelaus, Lyciscus, and Thrasycrates, and to say of them, as with Gruen, that they "suited the speakers' purposes and fitted Polybius' conception. That they determined anyone's behaviour, however, is illegitimate inference". ${ }^{280}$ Similar to Gruen's view that these speeches were "delusions", Waterfield suggests that any language of this sort owed itself more to rhetorical propaganda than to any third century "realities", and that the causal effects of these ideas were somehow divorced from those of Greek interests. ${ }^{281}$ This distinction of a "real" set of circumstances from an ideal one draws these kinds of analysis, at their heart, towards the kind of structural Neorealism more strongly embodied by the likes of Eckstein. But one might be entitled then to ask what those speakers' purposes were - if indeed they were somehow still suited, as Gruen suggests - and why we ought not to consider alternative, positive Greek characterisations of Rome or, for that matter, any other state. As it happens, the direct Spartan response to the speeches of Chlaeneas and Lyciscus, if given by Polybius, has not

\footnotetext{
${ }^{278}$ Gilbert 2010, 6.

${ }^{279}$ Nabis, for one, would have much to say on these latter considerations in 195: Livy 33.31-3.

${ }^{280}$ Gruen 1984, 324.

281 See Waterfield 2014, 57-8, with Gruen 1984, 325. Waterfield is nevertheless happy to see cultural explanations as bearing on Roman behaviour, but not Greek. Gruen likewise later seeks to have it both ways (397-8), as we shall see.
} 
survived. But we do possess a rare editorial statement in the Histories which states that

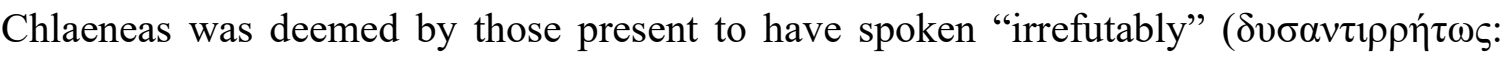
9.31.7). We might therefore be entitled to assume that Sparta decided to join the RomanAetolian coalition on the basis of Chlaeneas' or a similar such model of Panhellenic argumentation, a positive attitude towards Rome which is absent from Gruen's discussion of the Greek view of Roman expansion at this time. ${ }^{282}$

Since Constructivists view interstate structure as possessing a social rather than material basis, we may see that, in instances such as these, the parameters which defined power and interest were themselves the effects of ideas. "Since the basis of sociality is shared knowledge," states Wendt, "this leads to an idealist view of structure as a "distribution of knowledge" or "ideas all the way down (or almost anyway)". ${ }^{283}$ While to the world of political science such a view remains novel, it has been common to sociologists and anthropologists for some time. Simply put, Spartan ideas, like Aetolian, Macedonian, Roman, or Hellenic ones, affected causal variables in the same way as did material forms of interest, and sometimes even constituted interests in and of themselves. Those interests, therefore, were generative, discriminating, and liable to "the organizational [and] selective nature of human perception, understanding and memory". ${ }^{284}$

For the Pergamenes, Eleans, and Messenians, like their Aetolian and Spartan allies, tolerance of Roman collaboration will have been eased by a Panhellenic grammar which stressed enmity towards Macedon, the other ostensible threat to Greek freedom. In this context, Low's metaphor of the diplomatic "comfort blanket" retains its force. ${ }^{285}$ Attalus' role in the Roman establishment of the cult of Magna Mater in 205 even suggests that, beyond a politics of alienation against Macedon, Pergamum was at this time beginning a politics of cultural assimilation with Rome. ${ }^{286}$ The decisions made between 203 and 200 by several Greek states to send embassies to Rome complaining about Philip are made less surprising when we see that they may not have been the first step in a Greek politics of Roman cultural assimilation, even if earlier phases sought chiefly to chip away at

\footnotetext{
${ }^{282}$ Gruen 1984, 316-25. Chlaeneas is referred to indirectly on p. 322, but no comment in made about him or about the nature of his argument.

283 Wendt 1999, 20.

${ }^{284}$ Lawson 2006, 21.

${ }^{285}$ Low 2018, 470 .

${ }^{286}$ On the Magna Mater account and its Greek mythical and religious implications: Ov. Fasti 4.247-348, with Gruen 1990, 5-33 and Burton 1996. On the politics of alienation, assimilation, and indeterminacy: Champion 2000 .
} 
Macedon's monopoly over the issue of Greek autonomy. ${ }^{287}$ It is worth remembering that, a little over a decade earlier, Corinth had invited the Romans, in the context of the aftermath of the Second Illyrian War, to participate in the Isthmian games as "honorary Greeks" (Polyb 2.2.4). ${ }^{288}$ The selective isolation of exclusively anti-Roman and, therefore, antiAetolian examples of Panhellenic language in this period appears itself to be an echo of a Polybian and Achaean bias, notorious in its attempts to disqualify the Hellenism of states in the Aetolian League, who in fact conceived of their interests according to similar cultural notions.

It is no coincidence that Panhellenic calls were loudest in times of extraordinary political and military crisis. ${ }^{289}$ The existence and invocation of "Hellenic" identity does not, however, make Hellenic interest a given. Nevertheless, claims to it remained rooted in cultural notions which were familiar to all - notions of kinship, language, education, religion, common fears and common values - and thus these groups are found to have expressed their interests with these recognisable hallmarks in mind. To recall Mitchell again: the idea of the Hellenes carried power; the community existed because they said it did; and Hellenic identity was necessarily connected to the self-interest of the group. ${ }^{290}$ Hence why the Aetolians and Acarnanians alike couched their pleas to the Spartans in Panhellenic terms. Sparta's foreign policy was rooted in, and therefore discussed in terms of, the broader Hellenic picture. But this did not preclude the significance of specifically Lacedaemonian cultural notions: their reputation for Peloponnesian authority; their proud military tradition; and an obstinate isolationism which regularly put the polis at odds with Macedon. ${ }^{291}$ Derow, then, does better to acknowledge the coexistence of Hellenic and Peloponnesian "pictures" which differentially coloured Spartan interests, but he too makes nothing of the currency of ideas as a means of infusing these pictures together in order to align Sparta's interests with Aetolia's. ${ }^{292}$ The explanatory power behind the claim that the Spartans sided with Aetolia "as a matter of self-interest" depends on rooting that interest

\footnotetext{
${ }^{287}$ On these embassies: Eckstein 2008, 181-230, where the move is described as a "diplomatic revolution". It is possible too that, as Walbank believes $(1981,233)$, the distinct change in Rome's diplomatic attitude in Greece after 200 reflects not only this, but a conscious effort to undo the terrible reputation which they garnered for themselves during the First Macedonian War.

${ }^{288}$ See above, n. 216.

${ }^{289}$ Champion 2004, 40.

${ }^{290}$ Mitchell 2007, 3.

${ }^{291}$ Examples of Sparta's historical resistance to Macedon: refusal to join Philip II's League of Corinth, the battle of Megalopolis, the Chremonidean and Cleomenean wars, and, indirectly, their rivalry with Philip's erstwhile allies, the Achaeans. Spartan nostalgia for their ancestral prostasia over the Peloponnese will also have contributed.

292 Derow 2003, in Erksine and Quinn 2015, 26.
} 
in the Spartans' conception of Self, which is to say in their conception of identity. ${ }^{293}$ The Greek ambassadors, both seeking to avoid being characterised as Sparta's Other by stressing their similarities and invoking Sparta's role in the Panhellenic tradition, could thereby make claims to know Spartan self-interest, to declare it mutual, and even to suggest what pragmatic steps ought subsequently to be taken.

\section{The Non-Belligerent View}

In any case, these speeches constitute only a part of the picture. We can gain further insight into Greek attitudes by putting the behaviour of the neutral states into broader context. Like the Macedonian-aligned states, neutrals accused the Aetolians of having endangered Greek independence. They did not decry Philip's aggressive Illyrian policy for obliquely dragging the Romans into Greece, but rather the Aetolians' betrayal of principle in consenting to an alliance with them. ${ }^{294}$ Even if some of the neutrals' private fears were really to do with the growing power of Philip, as Livy implies (27.30.5), their goal remained a resolution of Greek conflict through derogatory and exclusionary characterisations of non-Greeks (like the Romans) and peripheral Greeks (like Attalus and, to an extent, the Aetolians). Thus they sought energetically to establish Greek safety by censuring the Aetolians and denying the Romans and Attalids the opportunity to intervene in Greek affairs. Insofar as Rhodes, Ptolemaic Egypt, Chios, and Byzantium were states with heavy dependence on maritime trade, their materialist opposition to the pro-Roman coalition makes sense: Rome's military presence was chiefly naval; and the Aetolians had a reputation for privateering, as did the Illyrians, many of whom were Roman amici. Unlike the Social War, however, wherein these very states addressed the same material problems by way of open, pragmatic talks about redressing trade interests in the Aegean and Adriatic seas, from 209 onwards neutral language also took on a radically idealistic tone. ${ }^{295}$ Although substantive, the trading states made practical, economic considerations part and parcel of a greater politics of Hellenism and cultural alienation. While some of these points have been touched on above, it is worth further unpacking them here, especially in terms of what they reveal about the peace of Phoenice, the settlement which ended the First Macedonian War in 205.

\footnotetext{
${ }^{293}$ Wendt 1999, 240.

${ }^{294}$ Eckstein 2008, 97.

295 The Social War, Rhodes, and Chios: Polyb. 5.24.11-2, 28.1-2; Ptolemaic Egypt and Byzantium: Polyb. 5.100.9-11. Commercial motivations of the Ptolemies: Manni 1949, 95; of the others: Huss 1976, 130. The Ptolemies likely also saw in the mediations an outlet to undermine the power of Macedon.
} 
In reviving the thesis of Maurice Holleaux, Eckstein has insightfully drawn attention to the significance of the Greek states that were not signatories to the peace of Phoenice, rather than to the significance of Greek states that were. ${ }^{296}$ In short, every neutral state that sought annually to end the Aetolian War in Greece is absent from the list of adscripti to the peace of Phoenice, which suggests that the goal of these mediators had been to resolve Hellenic conflict, with little to no consideration of Roman interests beyond their presence in Hellas. It was not a comprehensive peace (i.e., one that includes Rome), in other words, that the neutral mediators were seeking. ${ }^{297}$ As Dmitriev rightly points out, this shows them as behaving traditionally. ${ }^{298}$ They endorsed the old ideas of separating the Greeks from the rest of the world and of claiming Greek affairs for themselves. Moreover, this also explains how - without objection from any other state, even Aetolia - Macedonian representatives were able to claim at every conference that they did not start the war which the Greeks were mediating. ${ }^{299}$ This is significant to our interests because it corroborates Polybius' claim that the neutral states in Greece were also ill-disposed towards Rome, but only insofar as such hostility owed itself to a symbiosis of preconceived notions about non-Greek behaviour and, as a result of Rome's conduct, the sense amongst many Greeks that such notions had been proven true. This is not evidence of an objective and unequivocal Greek political attitude towards Rome, but rather it shows the profound extent of a cultural stereotype. We should remember that such stereotypes were expressed towards other states besides Rome: Rome's Greek amici continued to cast Macedon with similar negativity; the conduct of Attalus was typically lumped in with Rome's reputation; and it is possible that even the neutrals also reserved criticisms of Philip which could not find proper voice.

The delimitations of the Peace of Phoenice in 205, as it were, suggest the existence of not two, but three factions in Greece: those who are pro-Macedonian (Achaea, Boeotia, Acarnania, Epirus, Thessaly and Bithynia); those who are pro-Roman (Pergamum, Sparta, Elis, Messene, and, dubiously, Athens and 'Ilium'); and those others who were either ambivalent or uncommitted (Rhodes, Ptolemaic Egypt, Byzantium, and Chios). ${ }^{300}$ These

\footnotetext{
${ }^{296}$ Eckstein 2002; 2008, 93-118, with Holleaux 1921, 35-8, 74-5 and Walbank 1967, 229 contra Schmitt 1957, 25-6; Rich 1984, 145-7.

297 The one instance where peace talks may have been comprehensive, we have seen, owed themselves to Philip's situation and, hence, to Philip's initiative.

298 Dmitriev 2011, 151.

${ }^{299}$ Eckstein 2008, 91-118.

300 The Aetolians simmered somewhere in between disillusionment with Rome and resentment towards Macedon, despite having made peace with Philip the year before. On the questionable inclusion of Athens and Ilium as adscripti on the Roman side: Badian 1958, 59. It is possible that Ilium is a reference to the Troad League of northwest Asia Minor, who had been allies of Attalus since 226: Waterfield 2014, 56n.26.
} 
factions' distinct material interests and war aims have been well noted. But we have now reemphasised some similarities in their identities and ideas: all the Greeks, despite myriad treaties and connections, characterised themselves as detesting the notion of foreign cooperation. For partisans of Philip, this meant coding Macedon along Hellenic lines, much like Isocrates or Speusippus in earlier centuries, and applying traditionally Persian and Carthaginian stereotypes of barbarism to the Romans. By contrast, for partisans of Rome, relative newcomers on the Hellenic scene, the immediate urge will not have been to cast them as philhellenes or benefactors; there seems to have been insufficient precedent to widely propagate this kind of sentiment until the turn of the century. Instead, these Greeks appealed to the alternative Panhellenic tradition of Macedon - namely the exclusionary, hostile, and Demosthenic one - in order to cast their opposition as alike being undertaken in the interests of Greek freedom. The neutrals, ostensibly freer from such pressures, claimed to represent the interests of Greek freedom along more generically negative lines - of keeping Hellenic affairs to themselves - despite being subject to their own biases.

\section{Magnesia on the Maeander (208/7)}

Finally, a general Panhellenic resurgence can contemporaneously be seen with a remarkable episode at Magnesia-on-the-Maeander. ${ }^{301}$ In 221/0, prior to the Social and Hannibalic Wars, the polis tried to proclaim a new Panhellenic festival and to acquire the status of inviolability (asylia), after an appearance of their patron deity, Artemis Leukophryene. ${ }^{302}$ This attempt failed to garner support and petered out. But in 208/7 a second attempt was made which in turn was astonishingly successful. The Magnesians sent ambassadors (theōroi) to Greek states everywhere "from Antioch in Persis to western Sicily", and were met resoundingly with favourable responses. ${ }^{303}$ Alongside the dozens of individual poleis who assented, the Boeotian, Achaean, Aetolian, Phocian, Acarnanian, and Epirote leagues all endorsed the proclamation, as did kings Ptolemy, Attalus, Antiochus, and Philip. ${ }^{304}$ This event has been described both as a moment of Hellenic "regeneration" in the late third century and as part of an eastbound "re-centring" of the Greek world. ${ }^{305}$

\footnotetext{
301 This is observed in a similar context by Derow 2003, in Erksine and Quinn 2015, 28. See also Dmitriev 2011, 151n.43.

${ }^{302}$ See Rigsby 1996, 66-131, who is the principal authority on the Magnesian inscriptions. On an Athenian inscription on relations to Magnesia in 208/7: $I G \mathrm{II}^{3}, 1,1170$.

${ }^{303}$ Kern 1901 and Derow 2003, in Erksine and Quinn 2015, 28, contra Sosin 2009, who believes that the Magnesians did in fact not try to acquire asylia until 208/7. On Roman reception of Greek religious and cult identity networks: Malkin 2011, 171-203.

${ }^{304}$ Derow 2003, in Erksine and Quinn 2015, 28.

305 "Regeneration": Mitchell 2007, 208-9; "re-centring": Parker 2004, 16.
} 
Through such widespread assent to the proclamation, the incident serves as a tangible reaffirmation of the bearing which cultural norms had on Hellenistic politics, especially at this time: the states involved all explicitly advertised their own Hellenism and willingness to both recognise and preserve that of others.

\subsection{Summary}

Taken in conjunction with the political outcries of anti-barbarian sentiment in Greece, the cultural reaffirmation of Hellenism signalled by events at Magnesia-on-the-Maeander points to a profound, if foreseeable, coalescence of Greek ideas with Greek interests. The Greeks conceived of this period of time as a consequential moment in their historical experience, and saw it as sharing continuities, both conceptual and pragmatic, with the two preceding major convulsions: the Persian Wars of the fifth century; and the rise of Macedon in the fourth. It does not therefore seem absurd, in keeping with Polybius and Champion, to deem the final decades of the third century as constituting the origins of a third convulsion, for we possess all the symptoms: a non-Greek military presence in Greece proper; various calls for a united front against barbarians which, just as in the fifth and fourth centuries, were often found to be contradictory or in competition; and an elevated, widespread, and explicit series of affirmations of states' commitment to the values and ideas of Hellenism. Alongside Derow, we must conclude that "there was clearly something in the air". ${ }^{306}$ It should also be reiterated that this process often operated beyond simple rationalism; for such conceptualisations would be neither pervasive nor effective unless a good portion of the audience deemed them to be relatable and sincere. All the Hellenised powers utilised and were receptive to barbarian paradigms - used in conjunction with paradigms about Greek freedom - as a means of propagating and distorting their identities. The particular uptick in the prevalence of ideas and culture in the politics of this period further underscores their importance in determining interest at both the Hellenic and state levels.

The Panhellenism of Agelaus, although defensively minded, is both idealistic and of a kind which encompasses Macedon into the Greek sphere. Alongside the fact that he called almost instinctively for the Greeks to oppose a nebulous and abstracted barbarian threat (here in the west), this conception evokes an Isocratean model of Panhellenism. In 211, however, the Romans came in force to Greece, and together with the Aetolians left a

\footnotetext{
${ }^{306}$ Derow 2003, in Erskine and Quinn 2015, 28.
} 
tangible, brutal impression on many powers. Coupled with the Greek states' (oftentimes begrudging) acquiescence to Macedon's position in the Greek world, and with Macedon's own careful cultivation of their Hellenic identity, several states therefore recast the versatile, negative Panhellenic mould to fit Rome - the new concrete threat to Greek security. This conception in turn resembles Low's negative, or Demosthenic model of Panhellenism. As regards questions of scholarship and historiography, the Romans were not the exclusive recipients of barbarian characterisations, though they appear to have been the most explicit. Greek states, both pro-Macedonian and non-belligerent, employed similar strategies of cultural alienation against the likes of Aetolia and Pergamum, despite their being Hellenistic powers themselves. Owing to the Aetolian League's opposition to the immense Hellenic Symmachy of Philip V, ostensible Hellenic opinion had been stacked against them since the 220s, which in part explains their attempt at the Peace of Naupactus to signal Aetolian reaffirmation of the norms and expectations inherent in Greek interstate behaviour. Dmitriev is right to state that viewing the speeches in Polybius as "documents of panhellenic resistance to Rome" can only be held as partially true. ${ }^{307}$ While some views are indeed downplayed, Polybius nevertheless presents alternative Panhellenic conceptions of interest besides those presented by the Achaean League and her erstwhile allies. Critically, Macedon had not altogether escaped the barbarian characterisation themselves. The speeches show that Rome constituted an (admittedly ample) part of a greater political cycle of traditional and cultural ideas, which not only continued to interrogate the status of Macedon, but also that of other Greeks.

${ }^{307}$ Dmitriev 2011, 150, quoting Mørkholm 1974, 132. 


\section{Chapter Three}

\section{The Greeks and Philip V (205-199)}

\subsection{Macedonian Aggression and Roman Rapprochement}

The preceding chapters dealt principally with the interconnected cultural notions of Panhellenism, freedom, and barbarism. From 217 to 205, a majority of Greek states had cultivated an image of fidelity both to the ideas of Hellenism and to other Greek states, and a concomitant image of opposition to those who were deemed to threaten Greek values and Greek freedom. This cultural politics was versatile, and it distorted the logic inherent in purely material or power-based assumptions of Greek behaviour. Outside of Greece, too, this politics left its mark. Philip's Hellenic reputation benefitted him throughout the Social and Aetolian Wars as a result of his assimilation with, and proactivity on behalf of, his Greek allies. The Hellenic Symmachy, with its large size and land-based influence, predisposed the cultivation of a widely positive view of Philip amongst several of the major powers. This extended even to some maritime neutrals, whose anti-Roman complaints we have previously noted, and to Crete, most of which had become confederated, with the king as their prostatēs.

This was not a free gift for Philip, as he rightly knew: in acquiring utilitarian benefits from the Symmachy (for, whatever else it was, it was certainly also a mechanism of Macedonian authority), he had appreciated how his position within it entailed responsibilities as well as benefits. By reviving the effective conditions of the Social War in Greece in 211, when Philip's foreign policy was more focused elsewhere, Laevinus and the Aetolians continued to heap the onus onto the king to maintain his hard-earned Hellenic influence through action. The resulting cost came in the way of regular disruptions of his Illyrian plans in order to help his beleaguered Greek allies; yet by and large, Philip appeared to have been willing to pay this price, and in so doing to have shown extraordinary energy. Thus Macedonian political aims were oftentimes achieved in conjunction with satisfying many of the Greeks' Panhellenic aspirations; indeed at times certain Hellenic ideas themselves became Philip's interests and political aims, whether or not he was also possessed of ulterior motives, and those aims prompted his cultivating a positive, and positively Greek, disposition. Even the Aetolians found themselves obliged at Naupactus to invoke him in that king-as-protector mould, as old as Isocrates, aware of the need to conform to a particular kind of Panhellenic consensus. By seeking through positive action to protect 
those in his alliance, Philip ensured greater security for himself and cultivated the goodwill of several of his Greek allies. As Perlman points out, it is an unnecessary simplification to see Macedonian interests and Greek Panhellenism as forces which were persistently and diametrically opposed. ${ }^{308}$ Nor do we need to prescribe to Philip an obstinate idealism in order to see the effects of his philhellenic self-image at work.

\section{Philip's Eastern Campaigns}

But despite his earlier career, Philip's policies and performativity - and subsequently his interstate reputation - undertook drastic changes between 205 and 200. For Walbank, this was a critical phase in his reign, marked by “important developments in Philip's ambition and character". ${ }^{309}$ And for several Greeks, these changes were deemed to have been much for the worse. Not only did Philip reinvigorate hostilities with Attalus and (indirectly) the Aetolians but, often unprompted, he attacked several formerly non-belligerent states, amongst them Athens, Rhodes, Byzantium, Cius, Thasos, Abydus, Cyzicus, and Egypt. In response, Athens would eventually join Rhodes, Pergamum, and others in forging a new anti-Macedonian coalition, separate from that which had been delimited by the adscripti to the Peace of Phoenice. ${ }^{310}$ Precisely why Philip forsook his old approaches and spheres of interest, in favour of pursuing a more assertive and independent eastern policy, is an issue that remains variegated and contentious. ${ }^{311}$ Perhaps he was restive about Illyria and, ironically, was wary of causing more Roman friction by looking west. The ambitions of Hellenistic monarchy and envy of Antiochus' massive esteem must have played some part. But what remains clear is that, after 205, Philip became more interested in maritime eastward expansion and less interested in juggling Greek sensibilities. ${ }^{312}$ For Polybius, the king's new policy signalled a severe advance in the kind of moral degeneration, for which the retributive Tyche would rise to punish him $(4.77 ; 7.12 ; 15.20)$; and indeed, the Achaean's editorialising serves as a useful, if partisan, insight into the monarch's Hellenic

\footnotetext{
${ }^{308}$ Here in the context of Philip II's fourth-century League of Corinth: Perlman 1985, 173, esp. n.97.

${ }^{309}$ Walbank 1940, 134.

${ }^{310}$ Philip also attacked states who shared sympoliteia with Aetolia: Walbank 1940, 121, 135 (cf. App. Mac. 4). This brief account naturally eschews certain nuances. Efforts to paint Philip in a single brushstroke are self-condemning, as Polybius himself is repeatedly made to concede (see esp. 16.28). It is Walbank 1940's summation of the king (275), as having led as much a life of energy and enterprise as one of ironies and paradoxes, which so lends to his appeal of study. For a full account of activity between 205 and 200, Walbank remains authoritative; but see also Eckstein 2008, 119-270; and Waterfield 2014, 62-73.

311 Some assessments of Philip's ambitions during this time: Walbank 1940, 108; Larsen 1968, 379; Gruen 1984, 533-4.

${ }^{312}$ Philip went about raising money to complete construction of a large fleet, the beginning of which had been undertaken at Cassandreia in 208: Walbank 1940, 108; Waterfield 2014, 63. He also seized a massive Ptolemaic fleet stationed at Samos in 201 (Polyb. 5.35.11).
} 
legacy. ${ }^{313}$ For our interests, the optics surrounding Philip's new activities matter because it was Greek outrage in reaction to them which instigated widespread shifts in policy—or so it was claimed by the several states who sent embassies denouncing Philip's barbarism to, of all people, the Romans.

\section{Society, Culture, and Structural Change}

By and large, modern accounts explain this subsequent Greco-Roman convergence with an eye towards the changing Hellenistic balance of power. By now, Antiochus had concluded his successful reconquest of large parts of Asia (known as his anabasis) and had returned to the Mediterranean, having taken on the epithet Megas, the Great, in clear emulation of Alexander. ${ }^{314}$ A simultaneous collapse of Ptolemaic power brought on by momentous rebellions in Upper and Middle Egypt in 207, and worsened by Ptolemy IV's death and succession by an infant in 204, caused Philip and Antiochus to conspire to expand their kingdoms at Ptolemaic expense (Polyb. 15.20). ${ }^{315}$ Naturally, states such as Rhodes and Pergamum, afforded a qualified degree of independence beneath the tripolar network of Hellenistic power - and indeed Athens, who had long enjoyed close ties to the Ptolemies grew anxious about the monarchs' aggressions in the Aegean and in Syria. ${ }^{316}$ Polybius

\footnotetext{
${ }^{313}$ The demarcation of Messene (as opposed to, say, Thermum in 218 or the Eastern Aegean in 203-2) as a sudden start to Philip's moral decline, while it may echo an (especially Achaean) contemporary bewilderment, is schematic: it was clearly more worrisome in the eyes of Polybius to violate Greek nomoi against the Messenians, then fellow members of the Achaean League, than to do so against the Aetolians. The Achaean League was itself brutal when dealing with a Messenian secession in 182, so we should be wary of his attempts to moralise here. On social revolution as a "spectre" which "haunted third-century Greece": Walbank 1940, 17, with Fuks 1984; for the Achaean case in particular: 73-4 and 273. Walbank 1940 (74) does well to observe that Aratus' plea was not mere idealism, and that Philip knew as much: Philip's Hellenic prestige had done much to win security and bolster manpower securing services in places as far away as Crete. A garrisoned Ithome would be of little use if its seizure estranged the Achaean League. As Aratus' repatriation of the Acrocorinth in 243 demonstrated, the symbolic power of these garrisons themselves constituted important political variables. And whatever Philip's ostensible vices, Aetolia's atrocities during and after 211 nevertheless effected his rapprochement with the Achaean League.

${ }^{314}$ Anabasis: Green 1990, 293. Roman anxieties about Antiochus were certainly compounded later in 195, when they found out that Hannibal had joined his entourage.

${ }^{315}$ Despite earlier doubts, it has since been proven that Philip and Antiochus both attacked Ptolemaic holdings at precisely this time, and acted non-aggressively with respect to one another. Before his campaigns, the Alexandrian government reached out to Philip for intermarriage (Polyb. 15.25.13). Philip then seized, or attempted to seize, the following Ptolemaic possessions: in Thrace, Aenus, Maeronea, Cypsela, Doriscon, and Serrheum; on the Chersonese, Elaeus, Alopeconnesus, Caillopolis, Madytus, Sestus and others (see Walbank 1940, 133); in the Aegean, Samos, Miletus, Theangela and parts of Bargylia (these given over to Antiochus' forces whilst they attacked Ptolemy), Cos and Calymnus, Heraclea-by-Latmus, and others possibly under Ptolemaic influence. An exhaustive analysis of these campaigns and their relevance to the pact between the kings is Eckstein 2008, 150-65. Antiochus on the other hand had shown desire - both before and after the period of 205-0 - to target Egypt itself, in 210 and 196: Eckstein 2008, 145. And a recent inscription of a Rhodian decree found on the coast of Bargylia states that Antiochus was attacking Ptolemy at the same time Philip was taking Theangela and the Bargylian hinterland: Blümel 2000, 94-6. See Eckstein 2008, 168-80 for more on Antiochus.

316 On the Attic resurgence of anti-Macedonian feeling: Walbank 1940, 124-5.
} 
evidently saw the pact of Philip and Antiochus as a fundamental part of his history; but its influence and even its existence have been debated by scholars $(3.2-5,15.20) .{ }^{317}$ Holleaux attributed grave importance to the pact, while Badian is amongst the more notable sceptics. Gruen prefers to walk a middle path, acknowledging its existence but suggesting it had minimal influence. ${ }^{318}$ But the argument for its centrality, as materially affecting the balance of eastern Mediterranean power and, to some extent, socially affecting states' conceptions of that balance, has received a recent and thorough revival by Eckstein. ${ }^{319}$ Notwithstanding the pact, it is uncontroversial to claim that between 205 and 200, the eastern Mediterranean was facing the commencement of what political scientists call a "power-transition crisis", wherein one (or more) major states undergo sudden decline or collapse, leaving a vacuum for another state (or states) to undertake a sudden rise. ${ }^{320}$ The rapid deterioration of Ptolemaic authority afforded Rome the chance to impede upon and replace the triadic system of eastern Mediterranean balance.

Since power-transition crises concern alterations to the balance of power, it is important to speak of what Realists call the process of balancing, believed to be an instinctive and defensive response by states to the pressures inherent in a system of international anarchy. ${ }^{321}$ This process suggests that, since there are strong tendencies towards prioritising security and self-defence, states look to make accommodations at the interstate level which - often subconsciously - "create roughly equal distributions of power between opposing states or coalitions of states". ${ }^{322}$ Since balancing is "above all a process", say the likes of Waltz, Lake, and Eckstein, states can be found forming balances of power whether they intend to or not. ${ }^{323}$ Eckstein's forceful espousal of this model offers an explanation for the rise of Rome that is rooted in the assumptions of Neorealism, minimising the social agency of the state-unit (Macedon, Achaea, Athens, Rome, etc.), in favour of the anarchical structure of the state-system at large. It is a framework that maps well onto Polybius' universal history.

\footnotetext{
${ }^{317}$ Amongst the more sceptical are Badian 1958, 64; and Harris 1979, 312 (esp. n.2). Green 1990, 308, while acknowledging the pact, minimises its importance.

${ }^{318}$ Except, perhaps, at Rome: Gruen 1984, 387-8.

${ }^{319}$ Eckstein 2008, 119-270. For the full list of scholarship on the pact between the kings: 129-31.

320 This theory, applied to Rome's conquest of the Greek east, was first pioneered by Eckstein 2008 (see in particular 125-6). The following section has substantial engagement with his work.

${ }^{321}$ The chief proponent of this kind of defensive neorealism is Waltz 1979.

${ }^{322}$ So Lake 2001, 62.

${ }^{323}$ Waltz 1979, 125; the quote: Eckstein 2008, 219.
} 
But even here, Eckstein must concede the impact of (particularly Greek) cultural factors in constituting the nature of this systemic change. Constructivists, we have seen, do not view interstate structures (like anarchy) or processes (like balancing) as intrinsic, natural, or reified. That is, although they can be seen to exist (and are therefore compatible with Constructivist thinking), they are not deemed to do so independently of the contingent historical realities, social processes, and identities of the actors who presuppose them. Greek self-interest, simply put, evolved as the product of Greek conceptions of the system, and not as that system's external or intangible driver. ${ }^{324}$ Ideational structures and agents, in the words of Copeland, "co-constitute and co-determine each other". ${ }^{325}$ And it is clear to see that, within this framework, many of the second-tier Greek states' cultural characteristics (phthonos, philotimia, the desire for freedom and autonomy, ideological opposition to barbarism) proved pivotal in determining the way in which this powertransition crisis happened. In this respect, Eckstein consequently qualifies the thrust of his methodology:

...it is reasonable to ask why these states [Pergamum, Rhodes, Athens, Aetolia], instead of turning to Rome for help, did not seek to make an accommodation with the rising power (i.e., adopt a stance of appeasement), or even decide to join with the monarchs to reap their own share of spoils from the faltering Ptolemies. In political-science typology, this type of conduct is called "bandwagoning" behaviour...one answer here may lie, by contrast [to the assumptions of Neorealism], in the impact of specific Greek cultural ideas. Instinctive balancing was clearly habitual among Greek states, and the entire history of Greek interstate relations is in one sense a history of wars of adjustment of the balance of power - wars of balancing process. Many factors - including the prevalence of multipolarity in itself - have been suggested as conducive to such balancing conduct; but one factor in Greek conduct may have to do with the prevalence of "honour [timēe]" as a social ideal among the slave-owning elites who were primarily responsible for determining policy in most Greek states, and the fact

\footnotetext{
${ }^{324}$ Wendt 1999, 368-9.

${ }^{325}$ Copeland 2006, 3.
} 
that the dominant social metaphor among those elites was the metaphor of "slave vs. free". Such cultural ideals militated against both appeasement and "bandwagoning," since such conduct might be seen as in itself dishonourable and/or "slavish," therefore ignoble, and hence to be avoided. In other words, cultural factors may have led Greek states more than modern states into following the pattern of alliance-formation in the face of the threat suggested by Walt. ${ }^{326}$

In contrast to the impact of Greek chauvinism and anti-Greek prejudice, we can see in this context how a variable like timē might distort a Greek state's process of balancing in a way that favours a rapprochement with Rome rather than with Philip. But Eckstein's remarks reveal the influence of more than just timē, or of the social dichotomy of slave versus free: we also see re-emerging the extent to which the Greeks' own process of balancing was embedded within their cultural tradition. Interstate arbitration, Eckstein rightly glimpses, was a centuries-long practice, which helped to enforce normative behaviours and political outcomes amongst Hellenic powers. The institution was ritualised, then, deeply rooted in Greek political philosophy, and had been built in as one of the many features of states' Hellenic identities. ${ }^{327}$ Put differently, rather than being a self-regulating quantity of the international system, the Hellenic balance of power was a norm which the Greeks had cultivated, come to know, and grown to act in accordance with. ${ }^{328}$ The socio-political consequences of failure to adhere had been illustrated as recently as in 210 by Galba and in 202 by Philip, each of whose respective blunders before Greek mediators at Aegina and Cius sparked outrage across the Greek world and augmented the intensity of their opposition (Polyb. 9.42; 15.22). Greek diplomatic norms will therefore have shaped Hellenic relations in a way which broader, systemic kinds of analysis might overlook. On a theoretical level, too, it may be worth here interrogating some of the structuralist or Neorealist assumptions which underlie frameworks of power distribution like multipolarity. A good rule of thumb, for instance, is that which is proposed by Wendt:

...when confronted by ostensibly "material" explanations, always inquire into the discursive conditions which make them work.

\footnotetext{
${ }^{326}$ Eckstein 2008, 219-20. The "suggested threat" is laid out in Walt 1987.

${ }^{327}$ See ch. 1 above, and again Berridge 2018, esp. 35ff.

${ }^{328}$ So Haynes et al. 2011, 222.
} 
When Neorealists offer multipolarity as an explanation for war, inquire into the discursive conditions that constitute the poles as enemies rather than friends. When Liberals offer economic interdependence as an explanation for peace, inquire into the discursive conditions that constitute states with identities that care about free trade and economic growth. When Marxists offer capitalism as an explanation for state forms, inquire into the discursive conditions that constitute capitalist relations of production. And so on. Enmity, interdependence, and capitalism are to a large extent cultural forms, and to that extent materialist explanations that presuppose those forms will be vulnerable to [this] kind of idealist critique. ${ }^{329}$

The power structures created in Greece by the Social, Aetolian, First Macedonian, and Second Macedonian Wars can alternatively be described as consisting of two multi-state bipolarities or, when we include the neutral bloc, a tripolarity. From a cultural perspective, as we have seen, several assertions amongst Greeks (chiefly in view of the wider world) suggest that they conceived of themselves as something of a unipolarity - as being united by common norms and a shared way of life. And if anything can be said collectively of the remarks of Socrates in the Republic (470c5-d1), of Aristotle in his Politics (1327b29-33), of Isocrates in his Panhellenic speeches, of Agelaus, Thrasycrates, or Chlaeneas, along with the Athenian, Macedonian, and other envoys at the various conferences near the end of the third century, it is that many believed the ideal aim of Hellenic mediations was the arrival of the Greek world at a state, if not of political unity, of permanent homonoia. Many may indeed have believed Philip's or other Greeks' conceptions of inter-Hellenic friendship to be "hardly worth the name", yet they continued until now to behave as if they were friends, hence remaining "friends in fact even if not in principle". ${ }^{330}$ At the Panaetolica of 199, even when Greek interest in Rome's war with Macedon was growing, Philip's envoys continued to push the line that all Greeks were enemies of such barbarians "by natureand nature is eternal" (Livy 31.29.15). Greeks and Macedonians on the other hand, they claimed, despite being united or divided by "important causes", remained conjoined by language, customs, and laws (Livy 31.29.12). To neglect elements of both the ideational

\footnotetext{
${ }^{329}$ Wendt 1999, 135-6.

${ }^{330}$ Wendt 1999, 305.
} 
and the Panhellenic - extensive in the spheres of diplomacy, civic oratory, and political philosophy - is to present an incomplete image of Greek politics. Such an environment militated states towards behaving (or wishing to be seen as behaving) in conformity to these principles, and towards cooperating with those deemed to be doing the same - a fact which has been well examined with respect to Rome (chiefly in tracing the policies of Flamininus), but has paradoxically lost some of its force with respect to Greece.

States like Rhodes, Egypt, and Athens had joined the likes of Pergamum and Aetolia, who had been hostile towards Philip during the Aetolian War, in part because they were unwilling to stomach the dishonour entailed in a policy of Macedonian bandwagoning or appeasement. Seen as a kind of a Panhellenic defender against the barbarian Romans not a decade before, the king's latest conduct had caused accusations of barbarism to be heaped upon himself. In addition to having attacked both the status and material possessions of these powers, Philip was now being perceived as Greece's reckless invader — as a king who attacked peaceful states and regularly contravened the customs of Greek warfare (Polyb 15.20, 22; 16.1; Livy 31.30). The Aetolians, though for the moment caught in a quagmire between Rome and Macedon, had long propped up a similar characterisation of the king. His sacking of Thermum in 218 - Aetolia's sanctuary and federal capital - the Aetolians compared to the transgressions of Philip II a century earlier, thereby sustaining the old image of a barbarian Macedon which endangered Greek security (Polyb. 9.28-30). ${ }^{331}$ Now, at last, this image finally appears to have gained traction beyond those few Greek states which had been a part of the Roman coalition during the Aetolian War.

The fact that Philip's Panhellenic gestures were now often seen through or rebuffed suggests that his fragile hold over Greek public opinion was beginning to crumble. ${ }^{332}$ Outraged as they were by the monarch's about-turn, states were obligated to couple their overseas appeals for freedom and aid with repudiations of Philip's claims to Greekness at home. ${ }^{333}$ So in 199 Athenian ambassadors decried Philip before the Aetolian League as a polluter of "all laws human and divine" for having ravaged Attica to a degree unparalleled

\footnotetext{
${ }^{331}$ On Thermum, see n.313.

332 Alongside Magnesia-on-the-Maeander, Philip continued to maintain a close association with Delos, supported the attempt by Teos to acquire asylia, and patronised lesser shrines at Lindus on Rhodes and Panamara in Caria. Walbank 1940, 270 puts Philip's religious inconsistencies down to their reflecting political rather than moral significance (see also 121n.3).

333 This outrage can be felt, amongst other things, in Athens' eradication of its two Macedonian demes, Antigonis and Demetrias, and imposition of the death penalty for speaking in favour the royal house: Walbank 1940, 140-1.
} 
since the Persian Wars (Livy 31.30.4). The Roman envoy, L. Furius Purpurio, was only too eager to further expose the hypocrisy of the king's Panhellenic line, reminding the dallying Aetolians that by now Cius, Abydus, Aenus, Maronea, Thasos, Paros, Samos, Larisa, and Messene had all levied the same complaints against him (Livy 31.31.4). And Polybius stresses that his now-habitual acts of impiety, illustrated sequentially at Cius, Pergamum, and Abydus, had simply confirmed malicious reports which his enemies had already circulated throughout the Greek world (15.22.2). Beyond the propaganda it must be conceded along with Walbank and Larsen that, by at least 202, Philip's campaigning had "brought out his ruthless qualities to an extent to which they had not so far been revealed". ${ }^{334}$ In that year the monarch enslaved the citizenry of Cius after offering the city peaceable terms, and gave it over to Prusias (who then named it after himself), ignoring the pleas of envoys from numerous Greek states who had come to him in order to mediate the fate of the Cians (Polyb. 15.22.1-3). Philip is reported to have mocked these ambassadors, and Polybius goes as far as to suggest that his latest outrages resolved the Rhodians henceforth to consider Philip their enemy, and "to never again hear a word in his favour" (15.22.5). The following year, entering Abydus after a bitter siege, Philip with the blackest irony ordered a three-day 'respite' within which the city's defenders might kill themselves, before his forces assumed control and took care of the rest (Polyb. 16.34.7-12). It will have constituted a lesser slight to mediators and, of course, to Philip's victims to implore the Romans than to any longer endure the complex politics of Macedonian accommodation and reconciliation-least of all when the king was attacking Greek states and ignoring Greek nomoi.

Philip himself, while slackening in his commitments to several Greek norms of interstate behaviour, doubtlessly continued to be affected in his decision-making by the extraordinary demands of machismo and personal militarism bound up in the ideology of Hellenistic kingship: nostalgia for the oikoumenē; the need to acquire "spear-won land" (doriktêtos chōra) and to maintain a largely wartime economy; to prove one's honour by way of martial achievement; and to keep peace at home by means of warring outside of it - an oddly paradoxical value for which, in Egypt, the Canopis Decree of 238 explicitly praises Ptolemy III (OGIS 96, 12-3, cf. Polyb. 18.51.3-6, 28.1.6). ${ }^{335}$ Philip's own timē, unquestionably insulted by the Romans' attempts to act before him on behalf of the Greeks

\footnotetext{
${ }^{334}$ Walbank 1940, 135; Larsen 1968, 379. See also Hammond and Walbank 1988, 413.

335 On Hellenistic monarchy as a political category: Eckstein 2013, 248-53.
} 
without any formal sanctions or alliances, must have played a role in his flouting of several Roman ultimatums in the leadup to the Second Macedonian War. ${ }^{336}$ Polybius personally acknowledges that, during the king's meeting with Lepidus, it was the Romans who had violated the spirit of the treaty that existed between them (16.34.1-7). The Romans had "no justice whatever in their demands", says Walbank, and De Sanctis is probably correct in suggesting that this made Philip think that the Greeks would likely rise and oppose them with him, despite their own growing list of Macedonian grievances. ${ }^{337}$ Moreover, submission, the option the Romans afforded to Philip at Abydus, bore consequences beyond the mere arbitration and loss of face which is sometimes suggested: the status of his kingdom and his freedom to pursue a foreign policy would suffer permanent damage. ${ }^{338}$ Gruen saliently observes in this context that "miscalculations are no small factor in the creation of war". 339 And however grey, the blend of Greco-Macedonian ideology encapsulated in the role of the Hellenistic monarch continued to shape Philip's political outlook, if not his religious or moral ones.

None of this should suggest that Greek appeals to Rome therefore came easily. Many of them appear to have been quite controversial and were sent only as matters of last resort, once states had exhausted themselves of alternative Hellenic solutions. On the one hand, it is true that Egypt and Pergamum had little difficulty, since both states shared traditions of diplomatic relations with Rome which, in the case of the former, stretched back as far as 272. ${ }^{340}$ But Athens only sent their ambassador, Cephisodorus, to Rome after they had failed to garner concrete assistance first from their benefactors and allies in Egypt, Pergamum, and Rhodes, and then from other states in Greece, chiefly in Crete and Aetolia (cf. Paus. 1.36.5). ${ }^{341}$ Similarly, the Rhodian embassy, sent in the summer of 201, arrived only after their already unprecedented political reconciliation with Pergamum, a reversal of thirty

\footnotetext{
${ }^{336}$ Green 1990, 307. Most scholars rightly make a lot of the fact that Philip was not used to being told what to do, let alone by a young Roman like Lepidus.

337 De Sanctis 1923, IV, I, 36, as adduced in Walbank 1940, 137, who puts this miscalculation down as “perhaps Philip's worst error". There were certainly also other factors: see Green 1990, 308 and Rosenstein 2012, 184. However ironically, Philip reminded Lepidus of their commitments to the peace terms inscribed in the treaty of Phoenice and was technically correct in saying that he had been responding to aggression started by Rhodes (Polyb. 16.34.7). On this, see Walbank 1940, 108-10. The Greek tradition, hostile to Philip, took his Asiatic campaigns to signal a rapid progression of his moral degeneration: Polyb. 8.4.4; Diod. 28.2. ${ }^{338}$ Rosenstein 2012, 184.

${ }^{339}$ Gruen 1984, 397, who is also quoted in Green 1990, 308.

${ }^{340}$ On these states' (particularly Pergamum's) relations with Rome: Evans 2012, 24-46. Pergamum, we have seen, also cooperated with the Romans. An earlier scholarly tradition, which held that Rome and Rhodes shared an old connection, has since come under dispute: cf. Gruen 1990, 9; Eckstein 2008, 30, 42n.58.

${ }^{341}$ Walbank 1940, 131-2. Athens' declaration of war against Philip in 200 only followed the granting (at last) of assurances from Attalus, the Rhodians, and Rome: Green 1990, 307.
} 
years of Rhodian-Attalid hostility which proved still insufficient to check the threat of Philip. ${ }^{342}$ And despite what Polybius says of their envoys at Cius in 202, the Rhodians evidently retained an influential pro-Macedonian faction when the Roman tour, headed by Nero, Lepidus, and Tuditanus, tumultuously arrived in $200 .{ }^{343}$ Tensions were further exacerbated by the simultaneous arrival of an Achaean mission, who thought it worthwhile to continue pushing a Panhellenic position of Macedonian cooperation. Despite having lost territory to Philip, having denounced him in the Roman senate, and having declared war on him, the redirection of Rhodian foreign policy down unprecedented avenues was clearly an uneasy process; and it would not be long until the Rhodians themselves came to resent Roman influence — not least when it benefitted Pergamum (Livy 14.5-10).

Additionally, while an Aetolian embassy to Rome is attested, and seems instinctive based on the policies of the last twenty years, it may not have actually occurred at all. ${ }^{344}$ If it did take place, as the ancient tradition asserts, it was in any case sternly rejected (Livy 31.29.4; App. Mac. 4). The dubious embassy notwithstanding, Aetolian relations with Rome remained cool until August 199, almost halfway through the Second Macedonian War; and all this despite their being Rome's natural Greek ally, and despite repeated appeals from Attalus in 201 and 200 to join in the war against Philip. Stirred at last by another Pergamene attempt, this time coupled with promises from Galba's lieutenant, L. Apustius, the Aetolians partook late on in the consul's thwarted invasion of Macedon by raiding Thessaly with Amynander. They failed in the end to link up with Galba before he was replaced by P. Villius Tappulus late in the autumn (Livy 31.15.9-10, cf. 31.40-1). ${ }^{345}$ It is probable by all accounts that lingering disillusionment from the First Macedonian War delayed any Aetolian dealings with Rome until it looked as though Philip had been gravely imperilled. Despite Apustius' promises to the league, the senate likewise felt betrayed over Aetolia's separate peace with Philip from 206 - a fact that M. Fulvius Nobilior would make patently clear in 189 (Polyb. 21.32).

\footnotetext{
${ }^{342}$ Eckstein 2008, 195-201.

${ }^{343}$ Waterfield 2014, 70-1.

${ }^{344}$ Its historicity is contested by a vein of scholars: Badian 1958, 208-11; Ferrary 1988, 51. On the scholarly debate, see Warrior 1996, 84; Eckstein 2008, 211-2.

${ }^{345}$ Waterfield 2014, 78-9, with Walbank 1940, 145.
} 


\subsection{The Resurgence of Anti-Macedonian Panhellenism}

\section{Shifting Identities, Shifting Perspectives}

States-systemic and metrocentric explanations of the Second Macedonian War often suppress the fact that Rhodes, Pergamum, Athens, and others were already at war with Philip before 200, a war which was joined - but not started - by Rome. From a Hellenic perspective, therefore, by the time of the Roman tour, and certainly once Galba had arrived on Corcyra in 200, negative and anti-Macedonian kinds of Panhellenism were the currencies with which many poleis were trading. By drawing Panhellenic aspects from each of the two preceding Greek historical convulsions, both Persian and Macedonian, the Greek powers had been able to generate and propagate principled, but often contradictory, selfimages - all while having their lived experiences altered, foreign policy attitudes reversed, and allegiances thereby changed. In this respect, here is an explanation of Roman imperialism which is pericentric: the positive assimilation of Rome into the 'protector' role was increasingly sanctioned by peripheral collaborators - Athens, Rhodes, Pergamum, and Egypt - in order to attack the fitful monopoly over that role held by Macedon since the reign of Philip II. ${ }^{346}$ The assimilation of Rome was at its strongest when Macedon minimised its commitments to Hellenic norms. The Athenians had used a similarly negative kind of Panhellenic logic to justify remarkable policy changes in the previous century; and the Achaeans, Spartans, Lampsacenes, and Smyrnaeans would all later partake in the enterprise of Roman assimilation for different reasons, whether to recalibrate their identities, to undermine the authority of Antiochus III, to augment that of the Pergamenes, or to simply prosecute local rivalries. While the long-term effects will have been difficult to pre-empt or discern, the Greeks were nevertheless exhibiting symptoms of the political science idea of "empire by invitation". 347 To be sure, these were still the early stages of transition and change: Philip V still had his Hellenic Symmachy, for instance, but some of its members were beginning to grow distant, and took up positions of neutrality when the Romans joined in the war against him. ${ }^{348}$ The bulk of favourable public opinion was certainly shifting, and from here it is generally agreed that, by his short-termism, recklessness, and underestimation of Greek outrage in response to his "barbaric" eastern policy, Philip had effectively shot himself in the foot:

\footnotetext{
346 This is the overarching thesis of Champion 2007 (see esp. 265-6, which unpacks the pericentric or "excentric" model of Roman imperialism).

${ }^{347}$ So Eckstein 2008, 291n.141, 246n.53.

${ }^{348}$ Notably Epirus and the Achaean League, who are discussed below.
} 
[Philip's] two great errors during the earlier period were the adoption of a western policy in 217 and the use of methods of barbarism in his eastern campaigns. ${ }^{349}$

...to the Greeks [Philip] would be the humbled aggressor and Rome the champion-a reversal of roles which his influence even among his old Greek allies could not long survive. ${ }^{350}$

...[Philip's] policy was intelligible but his methods can only be described as suicidal. It is doubtful whether any immediate gains he made outweighed the damage that these piratical activities did to his reputation...It is interesting how quickly Rome, not long since a disregarded barbarian interloper, [could] become a kind of general arbiter of Aegean affairs. ${ }^{351}$

In now assessing Rome's motives for the Second Macedonian War, Gruen appears to have it both ways. Only in this context is it acknowledged that Panhellenic discontent from 211 to 205 had in fact been widespread and consequential:

The Republic's previous engagement in the "First Macedonian War" had left a tarnished image — and a bad taste in the mouths of Greeks. Her armies had been brutal, giving rise to charges of barbarism...That was a past she had to live down...The senate could now put on show its vigor and integrity, and erase its prior reputation in Hellas. ${ }^{352}$

Most scholars already take the view that Philip's (and, formerly, Rome's) disregard for Greek cultural norms animated the subsequent Hellenistic power-transition crisis in a serious way. A Constructivist assessment of this fact merely redoubles the confidence with which this claim can be made, and thereby discounts the anxious, Machiavellian corollary which often accompanies it: that in acknowledging the role of these norms in interstate politics, we somehow risk being misled by those who cynically vaunted them; that they had little to no actual bearing on the behaviours of states who were moved in reality only by

\footnotetext{
${ }^{349}$ Walbank 1940, 272.

${ }^{350}$ Badian 1958, 69

351 Green 1990, 306.

352 Gruen 1986, 397-8. This view is also shared by Rosenstein 2012, 183.
} 
abstracted and structurally determined drives towards the acquisition of power, wealth, and territory. It is worth once again recalling Low here: "an investigation of the norms of interstate relations must take as its starting point the possibility - even the probability - that, in appealing to those norms, everyone could be lying; but it should also insist that the truthvalue of such claims does not have any necessary bearing on their potential impact on the practical conduct of interstate relations". ${ }^{353}$ Additionally, as we have seen, hard-headed provisos of this kind usually build in political effects which are brought about by ideational, which is to say cultural, forms: ambition, martial skill, and the projection of images of wealth and prosperity are all traits emphasised in the identities of the actors who, as Eckstein is ultimately right to say, oftentimes saw themselves as competitors in a kind of anarchic interstate environment. ${ }^{354}$ The latter remains a social claim, however, since this conception of interstate structure is nevertheless something "carried in the heads of agents" and "instantiated in their practices". 355 Adjacently, for example, if indeed at Rome in 200 "Realists among the patres will have expected war" with Macedon, as Rosenstein states, then they may also have hastened its onset by way of their expectations. ${ }^{356}$ The fact that purely self-interested conceptions of state behaviour create and help to reproduce certain international cultures is one of Wendt's foremost criticisms of Realism:

Realism's commitment to self-interest participates in creating and reifying self-help worlds in international politics. To that extent Realism is taking an at least implicit stand not only on what international life is, but on what it should be; it becomes a normative as well as a positive theory. Making the constructivist move of seeing egoism as always at stake in the social process helps us see that self-interest is not some external deus ex machina driving the international system, but itself an on-going product of the system. If self-interest is not sustained by practice it will die out. The possibility of structural change is born out of that fact. ${ }^{357}$

With this in mind, cultural assumptions re-emerge to shape the ways in which Hellenistic statesmen determined the poles of enmity and friendship, to affect how they acted in

\footnotetext{
${ }^{353}$ Low 2007, 257.

${ }^{354}$ Eckstein 2008, 229 implicitly acknowledges that qualities of ancient states such as militarism, bellicosity, and diplomatic aggression constituting "internal cultures".

355 Wendt 1999, 368.

${ }^{356}$ For the quote: Rosenstein 2012, 185.

357 Wendt 1999, 368-9.
} 
response to their perceived enemies, and to colour how they constructed meaning from one context to another. This suggests a process which has the potential to operate beyond simple rationalism: Constructivists suggest that sometimes (but, crucially, not always) "more is going on in those choices than just the squaring of means to ends", which is to say that actors might do more than adjust their behaviour in response to environmental changes only to satisfy fixed identities and interests. ${ }^{358}$ Like material and structural factors, ideas and agents were effective in bringing about the Hellenistic power-transition crisis because they too were in process. That is, the agents were themselves at stake - their properties (identities and interests) rather than just their behaviours - and they performed and reproduced their identities, "narratives of who they are, which in turn constitute the interests on the basis of which they make behavioural choices". ${ }^{359}$ Panhellenism owes its flexibility to the diversity of its elements: it is a tradition framed on one hand by positive and idealistic Persian antecedents, and on another by negative and pragmatic Macedonian ones. Such a range in turn afforded individual states a diversity of Panhellenic self-images, all of which remained, despite their differences, rooted on some level within an overarching cultural framework centred on safeguarding Greek freedom. We have just seen this illustrated in Greek responses to Philip's aggressions, where some states, seeking help from the west in part because of Philip's slights against their time, co-opted the barbaros paradigm as it had recently been applied to the Romans and threw it back on Macedon, recalibrating their conceptions of Self and Other in the process: to wit, recalibrating their conceptions of identity.

\subsection{Summary}

Some of the Greek states' idiosyncratic behaviours appear to stem from the successes of Philip's early strategies of cooperation, integration, and cultural assimilation, strategies which made his kingdom's interests seem commensurate with certain perceptions of Hellenic interest even when he attacked and enslaved other Greeks. Philip's networks of alliances and informal ties (like philia) led many to support him through loyalty and gratitude, but also to detest him as a moral degenerate when he was deemed to have betrayed his Greek principles and Greek allies. ${ }^{360}$ Phthonos and philotimia not only drove Philip's opportunistic and reactionary politics, but led several outraged Greek states

\footnotetext{
358 This is a summary claim of Wendt 1999, On the rationalist model: Wendt 1999, 116-30.

359 Wendt 1999, 366.

${ }^{360}$ On Philip's ties of philia: Gruen 1984, 76-86.
} 
towards Rome. These states continued to try and manipulate the struggles of the stronger powers in order to advance more immediate interests at the local level; and indeed, particularism, eleutheria, and autonomia made several Greek states resent having to be involved at all. Alongside power and materialism, all such cultural phenomena remained on hand, “equally real and constraining", to inform actors' conceptions of interest. ${ }^{361}$ The role of such phenomena was merely contingent on the contexts of meaning which those actors built around themselves, around interstate society, and around the nature of Macedonian authority in the Greek world. We are reminded that "the key is to reclaim power and interest from materialism by showing how their content and meaning are constituted by ideas and culture". ${ }^{362}$ Insofar as a state's Hellenic identity is made conspicuous through its association to Hellenic ideas, such ideas presuppose that state's interests and actions, however romantic or Machiavellian we may subsequently judge them to have been.

${ }^{361}$ Wendt 1999, 136.

362 Wendt 1999, 371. 


\section{Conclusion}

The turn of the twenty-first century CE has coincided with a resurgence in the politics of culture and identity. Simultaneously, academia's cultural turn has facilitated our acquiring better tools and models with which to understand and engage with this reality. In the ancient world, as everywhere else, a similar politics was ongoing; but certain discursive parameters have emerged which have until recently emphasised Greek geopolitical interests at the end of the third century at the expense of Greek ideas: a tendency to prioritise theories of imperialism when Rome encounters Greece; suspicions that the universal and cognitive elements of Polybius' history reflect only his worldview; and a principally Realist discursive apparatus which not only sees multipolarity as the origin for war, but implicitly builds in cultural forms when defining its poles. To be sure, material considerations were important; but we should not overlook the ideological meaning which contemporaries attached to them, insofar as it was through that meaning that they became interests, and insofar as that meaning is derived from the social environment-from actors' perceptions of the system in which they lived. The Greeks' political culture was introspective and nostalgic, yet it remained imbued with a sense of continuity spanning the fourth and fifth centuries. It was not yet an environment in which we might detect a belatedness, or the feeling of disconnect inscribed in the works of Plutarch and other Greeks writing in the Second Sophistic.

Moments of external shock struck at the very notions that constituted Greek society, modifying the outlook and self-understanding of its members. They caused key norms to be recalibrated and reproduced; and so Greek ideas and identities likewise underwent changes as their material circumstances and pragmatic concerns changed around them. Hellenic identity was hardened by the Persian Wars, and became conspicuous in many respects through its opposition to barbarism. Macedon's ascendency then presented the Greeks with a new, liminal, and complicated Self-Other binary, which was more polarising in Greece and so diversified the available range of Panhellenic attitudes. The overlapping influences of these shocks created a dissonance amidst familiar Greek ideas, to the extent that Isocrates sought Philip II to lead a Panhellenic crusade against Persia, while Demosthenes sought tooth and nail to muster a Panhellenic opposition to him, an opposition which stretched as far as to include Artaxerxes. Similarly, at the end of the third century, some states which had assimilated Philip V sought his help in opposing Rome, 
while others conformed to a more negative Panhellenic line, deploying Roman aid instead to combat Macedonian authority over the Greek peninsula.

Selective memories of the Greek past and its socio-political heritage allowed for a variety of interests to be discussed using the same language. Many explanations of Greek behaviour owe themselves to matters of local politics, expediency, and cynicism, it is true; but even these prisms of interest are shown to have been underlaid and informed, at their root, by an intricate, often incompatible nexus of civic and Hellenic sensibilities, which Macedonian and, later, Roman assimilation helped further to blur and to complicate. The subsequent issues of Greek freedom in the half-century spanning Flamininus' Isthmian declaration down to the Achaean War in 146 have been well explored; but these ideas and their prevalence did not emerge from nowhere. Nor can their manipulation have been as effective as is always asserted unless these ideas had some bearing on the mechanics of the political process. Many may well have earnestly aspired to "free the Greeks", and others may have touted as much while harbouring nefarious designs. In either case, subdividing the "Hellenic" level of obligation were various sets of interests simultaneously informed by obligations to the political faction, polis, kingdom, or federal state; and however capricious some of those obligations were, they remained presupposed by Greek notions, Greek ideas, and Greek prejudices.

Through adherence to a Wendtian form of Social Constructivism, this study has prioritised the social and sociological aspects of ancient politics, and has sought to reemphasise its connection to history and culture. Necessarily, opportunities for simultaneous readings of events through rationalist or Realist lenses have in many places been relegated to the margins, or else passed over; but there are numerous studies to this effect which forcefully advocate for the roles of power, fear, and security in the Hellenistic arena, and which offer detailed models of the Greek world's anarchical composition. While seeking to revive the role of rational choice in the international process, this study has also reinforced Social Constructivism's role as a critique or modification of other theories, underlining how it is in many respects compatible with certain elements of Realist (and Liberal) schools of thought. Rather than suggesting that Realist assumptions should be altogether absent from explanations of behaviour throughout Greek history - least of all in the period spanning the Roman conquest - it has outlined some of the instances and processes whereby Greek ideas came either to distort behaviour, or even to create the very contexts of meaning which constituted the interests of states and agents. The result is to revive the roles of ideas and 
identity in animating the politics of the Greek world, and to qualify the predominance of studies which fall back on claims about "human nature", or else focus on rigid and structural models of interstate anarchy and violence. 


\section{Bibliography}

D. Abrams, M. Hogg. 2006. Social Identifications: A Social Psychology of Intergroup Relations and Group Processes. London.

F. E. Adcock. 1948. 'The Development of Greek Diplomacy', in L'Antiquité Classique Vol. 17. No. 1. 1-12.

E. Adler. 1997. 'Seizing the middle ground: constructivism in world politics', in European Journal of International Relations. Vol. 3. No. 3. 319-63.

S. L. Ager. 1997. Interstate Arbitrations in the Greek World, 337-90 B.C. California.

G. Allison. 2017. Destined for War: Can America and China Escape Thucydides's Trap?. Cambridge, MA.

R. Aron. 1973. Peace and War: A Theory of International Relations. New York.

D. Asheri. 1988. 'Carthaginians and Greeks', in J. Boardman et al. (eds.). The Cambridge Ancient History, Vol. 3. Cambridge. 739-90.

N. G. Ashton. 1984. 'The Lamian War: stat magni nominis umbra', in The Journal of Hellenic Studies. Vol. 104. 152-7.

R. Balot. 2006. Greek Political Thought. Oxford.

E. Badian. 1952. 'Notes on Roman policy in Illyria (230-201 B.C.)', in PSBR. Vol. 20. 7293.

1958. Foreign Clientelae. Oxford.

F. Beck. 1966. 'Greek Education-In Fact and Fiction', in The Australian Journal of Education. Vol. 10. No. 2. 193-201.

M. Berent. 1998. "“stasis", or the Greek Invention of Politics', in History of Political Thought Vol. 19. No. 3. 331-62.

I. Berlin. 1969. 'Two Concepts of Liberty', in Four Essays on Liberty. Oxford. 118-172.

G. R. Berridge. 2018. The Diplomacy of Ancient Greece: A Short Introduction. Leicester.

A. Björkdahl. 2002. 'Norms in International Relations: Some Conceptual and Methodological Reflections', in Cambridge Review of International Affairs, Vol. 15. No. 1. 9-23.

W. Blümel. 2000. 'Ein rhodisches Dekret aus Bargylia', in Ep. Anat. Vol. 32. 94-6. 
P. A. Brunt. 1978. 'Laus Imperii', In P. D. A. Garnsey and C. R. Whittaker (eds.). Imperialism in the Ancient World: Cambridge University Seminar in Ancient History. Cambridge. 159-91.

S. Bruskin. 2019. 'Insider or outsider? Exploring the fluidity of the roles through social identity theory', in Journal of Organizational Ethnography. Vol. 8. No. 2. 159-70.

J. Buckler. 1994. 'Philip II, The Greeks, and The King 346-336 B.C.', in Illinois Classical Studies. Vol. 19. 99-122.

1996. 'Philip II's Designs on Greece', in R. W. Wallace, E. M. Harris (eds.). Transitions to Empire. Oklahoma. 77-97.

P. J. Burton. 1996. 'The Summoning of the Magna Mater to Rome (205 B.C.)', in Historia. Vol. 45. No. 1. 36-63.

I. Carter. 2003. 'Positive and Negative Liberty', in E. N. Zalta (ed.). The Stanford Encyclopedia of Philosophy. Accessed 13 Aug. 2020. https://plato.stanford.edu/archives/win2019/entries/liberty-positive-negative/.

P. Cartledge. 1993. The Greeks. Oxford.

G. Cawkwell. 1978. Philip II of Macedon. London and Boston.

C. Champion. 1997. 'The Nature of Authoritative Evidence in Polybius and Agelaus' Speech at Naupactus', in TAPA. Vol. 127. 111-128.

2000. 'Romans as BAPBAPOI: Three Polybian Speeches and the Politics of Cultural Indeterminacy', in Classical Philology. Vol. 95, No. 4. 425-44.

2004. Cultural Politics in Polybius' Histories. California; 2007. 'Empire by Invitation: Greek Political Strategies and Roman Imperial Interventions in the Second Century B.C.E.', in TAPA. Vol 137. Baltimore. 254-70.

T. Christiansen, K. E. Jorgensen, and A. Wiener (eds.). 2001. The Social Construction of Europe. London.

A. Clark. 2010. 'Politicians Using History', in Australian Journal of Politics and History. Vol. 56. No. 1. 120-131.

D. Copeland. 2006. 'The Constructivist Challenge to Structural Realism: A Review Essay', in S. Guzzini; A. Leander (eds.). Constructivism and International Relations. Oxford.

J. Davidson. 1991. 'The Gaze in Polybius' Histories', in The Journal of Roman Studies. Vol. 81. 10-24.

P. Derow. 2003. 'The Arrival of Rome: from the Illyrian Wars to the Fall of Macedon', in A. Erskine (ed.). A Companion to the Hellenistic World. Oxford. 51-70. 
C. Th. Dimaras. 1992. 'Greece 1750-1850', in K. J. Dover (ed.) Perceptions of the Ancient Greeks. Oxford.

S. Dmitriev. 2011. The Greek Slogan of Freedom and Early Roman Politics in Greece. Oxford.

G. Dobesch, 1968. Der panhellenische Gedanke im 4 Jh. v. Chr. und der Philippos des Isokrates Untersuchungen zum korinthischen Bund. Vienna.

A. M. Eckstein. 2002. 'Greek Mediation in the First Macedonian War, 209-205 B.C.', in Historia. Vol. 51. No. 3. 268-97.

2006. Mediterranean Anarchy, Interstate War, and the Rise of Rome. California. 2008. Rome Enters the Greek East. Oxford.

2012. 'Polybius, Phylarchus, and Historiographical Criticism', in Classical Philology. Vol. 108. No. 4. Chicago. 314-338.

2013. 'Hellenistic Monarchy in Theory and Practice', in R. Balot (ed.). A Companion to Greek and Roman Political Thought. Blackwell. 247-66.

V. Ehrenberg. 1960. The Greek State. Oxford.

A. Erskine and J. Quinn. 2015. Rome, Polybius and the East: the Collected Papers of the Late Peter Derow. Oxford.

J. A. Evans. 1979. 'Herodotus and Athens: The Evidence of the Encomium', in L'Antiquité Classique. Vol. 48 No. 1. 112-8.

R. Evans. 2012. A History of Pergamum: Beyond Hellenistic Kingship. London.

J. Farrell. 2005. 'The Augustan Period: 40 BC-AD 14', in S. Harrison (ed.). A Companion to Latin Literature. Blackwell. 44-57.

J. L. Ferrary. 1988. Philhellénisme et impérialisme: Aspects idéologiques de la conquête romaine du monde hellénistique. Rome.

M. I. Finley. 1962. 'The Athenian Demagogues', in Past and Present. Vol. 21. No. 1. 324.

M. A. Flower. 2000a. 'Alexander the Great and Panhellenism', in A. B. Bosworth and E. J. Baynham (eds.). Alexander the Great in Fact and Fiction. Oxford. 96-135. 
2000b. 'From Simonides to Isocrates: The Fifth-Century Origins of Fourth. Century Panhellenism', in Classical Antiquity. Vol. 19, No. 1. 65-101.

M. Fragoulaki. 2013. Kinship in Thucydides. Oxford.

T. Frank. 1914. Roman Imperialism. New York.

A. Fuks. 1984. Social Conflict in Ancient Greece. Jerusalem.

D. T. Gallagher. 1993. 'Realism and Moral Enlightenment in Machiavelli's "Discourses on Livy"'. Dissertation. Boston.

J.F. Gaertner (ed.). 2007. Writing Exile: The Discourse of Displacement in Greco-Roman Antiquity and Beyond. Leiden.

P. Gilbert. 2010. Cultural Identity and Political Ethics. Edinburgh.

J. D. Grainger. 2017. Great Power Diplomacy in the Hellenistic World. London and New York.

J. R. Grant. 1965. 'A Note on the Tone of Greek Diplomacy', in Classical Quarterly. Vol. 15. No. 2. 261-266.

B. Gray. 2015. Stasis and Stability: Exile, the Polis, and Political Thought, c.404-146BC. Oxford.

P. Green. 1990. Alexander to Actium: The Historical Evolution of the Hellenistic Age. California.

2004. From Ikaria to the Stars: Classical Mythification, Ancient and Modern. Texas.

E. S. Gruen. 1984. The Hellenistic World and the Coming of Rome, 2 Vols. California.

1990. Studies in Greek Culture and Roman Policy. Leiden.

S. Guzzini. 2000. 'A Reconstruction of Constructivism in International Relations', in European Journal of International Relations. Vol. 6. No. 2. 147-82.

E. Hall. 1989. Inventing the Barbarian. Oxford.

J. M. Hall. 2002. Hellenicity. Chicago.

N. G. L. Hammond and F. W. Walbank. 1988. A History of Macedonia: Volume III: 336167 B.C. 1st Edition. Oxford.

M. H. Hansen. 1991. The Athenian Democracy in the Age of Demosthenes. Oklahoma. 2000. A Comparative Study of Thirty City-State Cultures. Copenhagen. 2006a. Polis: An introduction to the ancient Greek city-state. Oxford.

W. V. Harris. 1979. War and Imperialism in Republican Rome, 327-70 B.C. Oxford. 
2004. 'On War and Greed in the Second Century BC', in C. Champion (ed.). Roman Imperialism. Blackwell.

G. Hawthorn. 2014. Thucydides on Politics: Back to the Present. Cambridge.

J. Haynes, P. Hough, S. Malik, and L. Pettiford (eds.). 2011. World Politics. Essex.

T. Hopf. 1998. 'The Promise of Constructivism in International Relations Theory', in International Security. Vol. 23. No. 1. 171-200.

S. Hornblower. 1991. A Commentary on Thucydides, Vol.1. Oxford.

2002. 'Greece: The History of the Classical Period', in J. Boardman, J. Griffith, and O. Murray. The Oxford History of Greece and the Hellenistic World. Oxford. 12455.

A. Jaskelevičius. 2018. 'How Does One Become a Greek, or On the Panhellenism in Xenophon's Anabasis', in Literatūra. Vol. 59. No. 3. 79-91.

D. Kagan. 1990. Pericles of Athens and the Birth of Democracy. London.

M. V. Kauppi. 1991. 'Contemporary International Relations Theory and the Peloponnesian War' in R. Lebow and B. Strauss (eds.), Hegemonic Rivalry: From Thucydides to the Nuclear Age. Westview. 101-124.

O. Kern. 1901. "Magnetische Studien”, in Hermes 36. 491-515.

J. Klabbers. 2016. International Law Documents. Cambridge.

W. J. Korab-Karpowicz. 2006. 'How International Relations Theorists Can Benefit by Reading Thucydides', in The Monist. Vol. 89. No. 2. Oxford.

2010. 'Political Realism in International Relations', in E. N. Zalta (ed.). The Stanford Encyclopedia of Philosophy (Summer 2018 Edition). Accessed 21 Aug. 2020. https://plato.stanford.edu/archives/sum2018/entries/realism-intl-relations.

D. A. Lake. 2001. 'Beyond Anarchy: The Importance of Security Institutions', in Int. Sec. Vol. 26. 129-60.

A. Lanni. 2008. 'The Laws of Warfare in Ancient Greece', in Law and History Review. Vol. 26. No. 3. 469-89.

J. A. O. Larsen. 1968. Greek Federal States: Their Institutions and History. Oxford.

S. Lawson. 2006. Culture and Context in World Politics. Basingstoke. 
R. N. Lebow. 1991. 'Thucydides, Power Transition Theory, and the Causes of War', in R. Lebow and B. Strauss (eds.), Hegemonic Rivalry: From Thucydides to the Nuclear Age. Westview. 125-65.

J. E. Lendon. 1994. 'Thucydides and the 'Constitution' of the Peloponnesian League', in Greek, Roman, and Byzantine Studies. Vol 35. No. 2. 159-77.

D.S. Levine. 2010. Livy on the Hannibalic War. Oxford.

E. Lévy. 1994. 'Le discours d'Agélaos de Naupacte', in L. Aigner Foresti et al. (eds.). Federazioni e federalismo nell'Europa antica. Alle radici della casa comune europea. Milan. 33-50.

A. Lintott. 1982. Violence, Civil Strife and the Classical City. London.

A. A. Long. 2008. 'The Concept of the Cosmopolitan in Greek \& Roman Thought', in Daedalus. Vol. 137. No. 3. 50-58.

N. Loraux. 1986. The Invention of Athens: The Funeral Oration in the Classical City. Cambridge: Harvard.

P. Low. 2007. Interstate Relations in Classical Greece. Cambridge.

2018. 'Panhellenism without Imperialism? Athens and the Greeks before and after Chaeronea', in Historia Vol. 67. No. 4.

T. J. Luce. 1997. The Greek Historians. London and New York.

E. Mackil. 2013. Creating a Common Polity: Religion, Economy, and Politics in the Making of the Greek Koinon. California.

C. W. Macleod. 1979. 'Thucydides on Faction (3.82-3)', in Proceedings of the Cambridge Philological Society No. 25. 52-68.

N. Mahadevan, A. P. Gregg, C. Sedikides, W. G. de Waal-Andrews. 2016. 'Winners, Losers, Insiders, and Outsiders: Comparing Hierometer and Sociometer Theories of Self-Regard', in Frontiers in Psychology. Vol. 7. No. 334. 1-19.

A. Malkin. 2011. A Small Greek World: Networks in the Ancient Mediterranean. Oxford.

M. M. Markle. 1976. 'Support of Athenian Intellectuals for Philip: A Study of Isocrates' Philippus and Speusippus' Letter to Philip', in The Journal of Hellenic Studies. Vol. 96. 80-99.

R. McShane. 1964. The Foreign Policy of the Attalids of Pergamum. Illinois. 
M. Miller. 2005. 'Persians in the Greek Imagination', in Mediterranean Archaeology. Vol. 19 No. 20. 109-23.

L. Mitchell 2007. Panhellenism and the Barbarian in Archaic and Classical Greece. Swansea.

T. Mommsen. 1903. Römische Geschichte. Berlin.

C. A. Morgan. 2015. 'Dyme' in Oxford Classical Dictionary. Accessed 17 Jan. 2021. https://oxfordre.com/classics/view/10.1093/acrefore/9780199381135.001.0001/ac refore-9780199381135-e-2322.

O. Mørkholm. 1967. 'The Speech of Agelaus at Naupactus 217 B.C.', in Classica et mediaevalia. Revue danoise de philologie et d'histoire. Vol. 28. 240-53.

1974. 'The Speech of Agelaus Again', in Chiron Vol. 4. Munich. 127-32.

J. Ober. 2008. Democracy and Knowledge. Princeton.

J. L. O’Neil. 2000. 'Royal Authority and City Law under Alexander and his Hellenistic Successors', in Classical Quarterly Vol. 50, No. 2. 424-31.

R. Osborne. 1993. 'Competitive festivals and the polis: a context for dramatic festivals at Athens', in A. H. Sommerstein, S. Halliwell, J. Henderson, and B. Zimmerman (eds.). Tragedy, Comedy, and the Polis. Papers from the Greek Drama Conference Nottingham, 18-20 July 1990. Bari. 21-38.

A. Osiander. 1998. 'Rereading early twentieth-century IR theory: Idealism revisited', in International Studies Quarterly. Vol. 42. 409-32.

M. Ostwald. 1969. Nomos and the Beginnings of the Athenian Democracy. Clarendon; 2009. Language and History in Ancient Greek Culture. Pennsylvania.

S. Parashar. 2019. 'Research Brokers, Researcher Identities and Affective Performances: The Insider/Outsider Conundrum', in Civil Wars, Vol. 21. No. 2. 249-70.

R. Parker. 2004. 'New "panhellenic" festivals in Hellenistic Greece”, in R. Schlesier, U. Zellmann (eds.). Mobility and Travel in the Mediterranean from Antiquity to the Middle Ages. Münster. 9-22.

S. Payrau. 1971. 'Eirenika. Considérations sur l'échec de quelques tentatives panhelléniques au IVe siècle avant Jésus-Christ', in REA 73. 24-79.

L. Pearson. 1972. 'Prophasis: A Clarification', in Transactions and Proceedings of the American Philological Association. Vol 103. 381-94.

1987. The Greek Historians of the West. Atlanta.

P. Pédech. 1964. La méthode historique de Polybe. Paris.

C. Pelling. 1996. 'The Triumviral Period', in A. K. Bowman et al. (eds.). The Cambridge Ancient History, Vol. 10. Cambridge. 1-69. 
S. Perlman. 1976. 'Panhellenism, the polis and imperialism', in Historia 25. 1-30.

1985. 'Greek Diplomatic Tradition and the Corinthian League of Philip of Macedon', in Historia Vol. 34. No. 2. 153-74.

M. Pohlenz. 1966. Freedom in Greek Life and Thought: The History of an Ideal (C. Lofmark, trans.). Heidelberg.

J. Price. 2001. Thucydides and Internal War. Cambridge.

K. A. Raaflaub. 1996. 'Born to Be Wolves? Origins of Roman Imperialism.' In R. W. Wallace and E. M. Harris (eds.). Transitions to Empire: Essays in Greco-Roman History, 360-146 B.C., in Honor of E. Badian. Oklahoma. 273-314.

2004. The Discovery of Freedom in Ancient Greece (R. Franciscono, trans.). Chicago and London.

J. Rich. 1976. Declaring War in the Roman Republic in the Period of Transmarine Expansion. Brussels.

2004. 'Fear, Greed, and Glory: The Causes of Roman War Making in the Middle Republic', in C. Champion (ed.). Roman Imperialism. Blackwell.

K. Rigsby. 1996. Asylia: Territorial Inviolability in the Hellenistic World. California.

N. Rosenstein. 2012. Rome and the Mediterranean, 290 to 146 BC. Edinburgh.

J. Ruskin. 1894. The Complete Works: Modern Painters: Volume the Fifth. New York.

E. Said. 1978. Orientalism. New York.

2000. Reflections on Exile and Other Essays. New York.

G. De Sanctis. 1923. Storia dei Romani, Vol. 4. Florence.

1934. Riv. Fil. LXII. 108-9.

I. Scott-Kilvert, W. J. Tatum, and C. Pelling. 2013. The Rise of Rome: Twelve Lives by Plutarch. London.

R. Sealey. 1993. Demosthenes and His Time: A Study in Defeat. Oxford.

N. Sheldon. 2012. 'Politicians and History: The National Curriculum, National Identity and the Revival of the National Narrative', in The Journal of the Historical Association. Vol. 97. 256-71.

J. D. Sosin. 2009. 'Magnesian Inviolability', in TAPA. Vol. 139. 369-410.

H. P. Stahl. 2003. Thucydides: Man's Place in History. Swansea.

R. Strootman. 2011. 'Kings and Cities in the Hellenistic Age', in O. M. van Nijf and R. Alston (eds.). Political Culture in the Greek City after the Classical Age. Leuven. 
W. J. Tatum. 2019. 'Greece for the Greeks: Plutarch's Aratus and Greek Chauvinism', in F. M. Simon, F. P. Polo, and J. R. Rodriguez (eds.). Xenofobia y racismo en el mundo antiguo. Barcelona. 69-85.

S. Usher. 2009. 'Oratio Recta and Oratio Obliqua in Polybius', in Greek, Roman, and Byzantine Studies. Vol. 49. 487-514.

F. W. Walbank. 1940. Philip V of Macedon. Cambridge.

1957-79. A Historical Commentary on Polybius, 3 Vols. Oxford.

1981. The Hellenistic World. Glasgow.

1963. 'Polybius and Rome's Eastern Policy', in The Journal of Roman Studies. Vol. 53. 1-13.

S. Walt. 1987. The Origins of Alliances. Cornell.

K. N. Waltz. 1979. Theory of International Politics. New York.

V. Warrior. 1996. The Initiation of the Second Macedonian War. Wiesbaden.

R. Waterfield 2014. Taken at the Flood. Oxford.

A. Wendt. 1999. Social Theory of International Politics. Cambridge.

H. White. 1973. Metahistory: The Historical Imagination in Nineteenth-century Europe. Baltimore and London.

I. Worthington. 1991. 'The Authenticity of Demosthenes' Fourth "Philippic", in Mnemosyne. Vol. 44. 425-8.

M. Zanin. 2017. 'Roman-Aetolian treaty', in Axon. Vol. 1. No. 2. 181-203. 